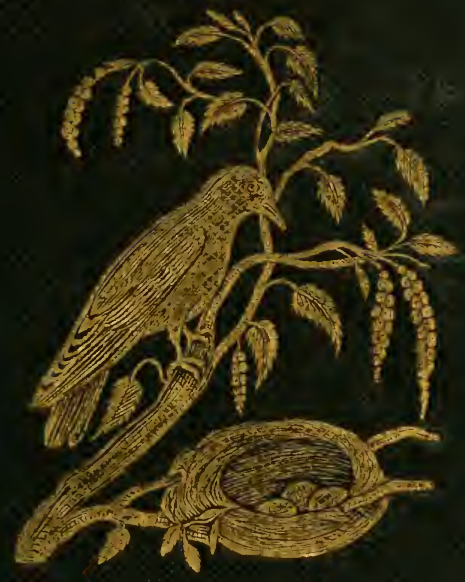





$$
\begin{aligned}
& \text { ENELISH CO W TONOON.W.1. } \\
& \text { 87. OHARLES STHES. }
\end{aligned}
$$




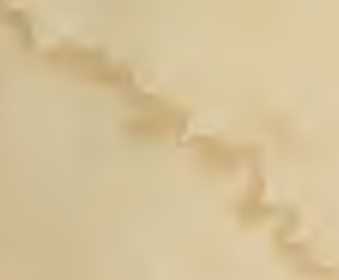




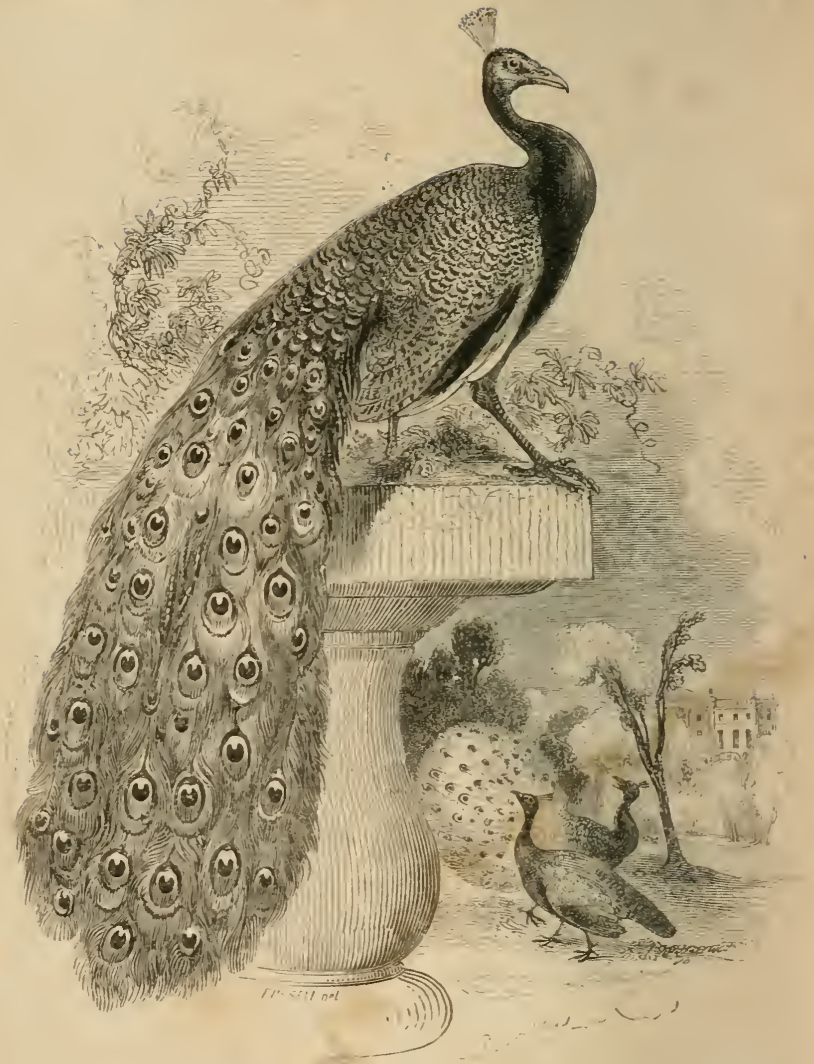




\section{BRITISH BIRDS.}

What tongue can tell

The mingled melodies, that mount, and swell, And float upon the flowery-scented gale, 'Wakening sweet echoes through the verdant vale!

Yet, not the feeblest note of forest bird, E'en by the brink of woodland waters heard, Nor loudest clarion that salutes the morn, But has some note of gladness still upborne A hymn of gratitude for life and light, To the clear heavens fresh opening on the sight.

Eltis.

\section{O N D O N : \\ THE RELIGIOUS TRACT SOCIETY;}

Instituted 1799.

SOLD AT THE DEPOSITORY, 56, PATERNOSTER ROW, AND 65 , ST. PAUL'S CHURCHYARD; AND BY THE BOOKSELLERS. 
LONDON :

PRINTED BY SAMUEL BENTLEY, Bangor House, Shoe Lane. 


\section{CONTENTS.}

THE PEACOCK.

Tris bird was imported by Solomon - Called originally the "bird of Media "-Its estimation in Greece and Lesser Asia - Singular story

THE GOLDEN EAGLE.

Various descriptions given by Naturalists - The habits of the Eagle described-Its range is very extensive - Attention of the parent-bird to her Eaglets - Allusion to it by Moses - Value of the word of GodAnecdotes of the Eagle

THE WHITE-TAILED EAGLE.

Its abodes on our own coast-Account of a pair of these birds in Ireland -Children carried away by Eagles . . . . . . . . 12

THE PEREGRINE FALCON.

Derivation of its name-Its eyries - Ancient passion for Hawking Estimation of Falconry in Wales - Appearance of the bird-The village of Falconswaerd-Decline of Hawking . . . . . . . . . 19

THE JAY.

Rich colouring of the bird - It is found in most of the wooded parts of this country-Its imitative notes . . . . . . . . 26

THE TITMOUSE.

Various species of this bird-Its note-Its habits - Varicty of its food

THE GULL.

Its resort ou the British coast-Perilous feats of schoolboys - Hazardous enterprizes of fowlers-Various anecdotes . . . . . . 
TH E STAN.

Wordsworth's description of this bird-Its nest-Its great age-Families of Swans on the River Thames . . . . . . . . 35

\section{THE S PAR R OW-HA WK.}

A common species in the enclosed parts of the kingdom - Habits of this bird - A pet Sparrow-hawk.

THE MOOR-F OWL.

This bird is found in mountainous situations-It is confined to the United Kingdom-Flocks of Moor-Fowl . . . . . . . . 41 THE PETREL.

"Mother Carey's Chickens"- These birds seen in great numbers all over the Atlantic-Immense stream of them-Superstition of sailors

THE NIGH T I GALE.

The largest of British warblers - Coleridge's description of the Nightingale-This bird is not found in Scotland - Its visits to various lands -Contrast to its brief song . . . . . . . . 46

\section{THE DOMESTIC COCK.}

Traced to the Jungle-fowls of India-Cock-crowing in the East-Varieties from the primal stock - Importation of eggs - Care of the Hen for her young - Allusion to it in the words of our Lord - Interesting story - Ingenious machine for accomplishing the process of incubationSingular and interesting facts . . . . . . . . 53

THE S PAR OW.

Its food - Its nests - Anecdote of a brood - Instance of fraud - Providence of God-Interesting fact

THE PHEASANT.

Splendour of this bird - Instinct of the Pheasant when sitting 76 
THE CUCKOO.

Wordsworth's address to it - Its egg laid in the nest of other birds Dr. Jenner's account

THE BLACKBIRD.

Its nest and song

THE WATER-O U Z EL.

Habits of this bird - An adventure in its pursuit
THE P I G E ON.

The Columbidæ - Beauty of Pigeons in the East - The Dove of NoahIntelligence conveyed by tame Doves - Presentation of Doves under the law of Moses-Sagacity of a Pigeon - Flights of Pigeons . . 94

\section{THE PARTRIDGE.}

A well-known bird-Its devices to save its brood - Adventure of Captain Head

TH E C A N A Y.

The "Talking Canary"-Singular story . . . . . . . 108

THE S K Y L R K.

The nest, brood, and song of this bird-The Lark an early riser . 113

\section{THE WREN.}

The favourite of one of our shepherd poets-Desire of birds to wash

themselves-Strength of parental feeling . . . . . . 118

THE WATER-WAGTAIL.

An active bird-It may become very familiar . . . . . . 123

THE LAPWING.

Curious fact-Stratagems of the Lapwing • • . . . . 125 
THE BULLFI NCH.

Page

Its low and plaintive call-An interesting pair of Bullinches-School for these birds

THE TURKE Y.

Its native country-Splendour of a wild Turkey Cock

THE CROW.

Its distinction from the Rook-Mr. Waterton's care for the Crow

.136 THE ROOK.

Its sagacity-Its sympathy-It is a friend to the farmer-Anecdote

THE SWALLOW.

Different species of this bird-Sir R. Grant's verses on the Swallow

THE GOOSE.

Its early domestication-Our obligations to this bird

THE BAR N.O WL.

Its continuance with us during the year-Its fondness for fish-Its mode of defence-Amusing fact

THE S I PE.

An unsocial bird-Its change of note

THE COMMON MALLARD.

Elegance of the Wild Duck-Advance of civilization

THE NIGH T-JAR.

Called in ignorance the Goat-sucker-It renders service to the grazier . 168 THE RAVEN.

An emblem of desolation-Punishment of disobedience to parents-Sagacity of this bird . . . . . . . . 170

THE COOT.

A common bird-Place of its nest 
A general favourite-Anecdotes of this bird . . . . . 177 THE STARLI N G.

A plentiful species-Power of imitation . . . . . . 183

THE GOLDFINCH.

Materials for a nest-The cherry-tree-Anecdote of Rev. H. Gauntlett . 185

TH E S WIFT.

Its resort to steeples, towers, and other lofty buildings-Its nest-Its destruction of insects-"God provideth for the morrow" . . . 191

THE MAGPIE.

Beauty of this bird in its native state-Variety of its food-A well-built nest-Anecdotes of Magpies-Advantages of judicious instructionEarly piety

TH E JACK DA W.

Places in which this bird is found-Remarkable story-Lessons suggested . . . . . . . . • . . 201 THE GREAT AUK.

Formerly found on the north coast of Britain-It is now extremely rare . 206 THE L IN N ET.

Variety of this species-Flocks of Linnets-Brilliancy and softness of their song

THE THRUSH

This well known bird described by Clare-It is found in various placesThe Red-wing-Influence of the notes of a Thrush on an invalid . 208

\section{THE CORMORANT.}

This bird may be observed on insulated eminences-Its dexterity in fish-

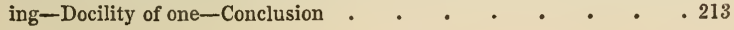




\section{LIST OF ENGRAVINGS.}

The Peacock . . . . . Frontispiece.

The Golden Eagle .

The Peregrine Falcon . . . . . . . 20

The Jay . . . . . . . . . . . . 26

The Gull . . . . . . . . . . 30

The Swan . . . . . . . . . . . 36

The Moor-Fowl . . . . . . . . . 40

The Petrel . . . . . . . . . . . 44

Domestic Fowls . . . . . . . . . . . 54

The Pheasant . . . . . . . . . . . 76

The Cuckoo . . . . . . . . . . 84

The Partridge . . . . . . . . . 106

The Skylark . . . . . . . . . . . 114

The Water-Wagtail . . . . . . . . . . 122

The Lapwing . . • . . . . . . . 126

The Turkey . . . . . . . . . . . 134

The Barn-Owl . . . . . . . . . 156

The Mallard . . . . . . . . . . 166

The Robin . . . . . . . . . . 178

The Goldfinch . . . . . . . . . 186

The Magpie . . . . . . . . . . . 196

The Great Auk . . . . . . . . . 206

The Redwing . . . . . . . . . . 210

The Cormorant . . . . . . . . . . 214 


\section{B R I T I S B I R D S.}

\section{THE PEACOCK.}

THIs beautiful bird was brought into Palestine in the reign of Solomon, from the countries farther to the east and south. That rich and powerful monarch had a taste for natural history, and, at certain times, his fleets returned laden with the most curious and valuable products of distant regions. No wonder, then, that his servants, struck by the elegant shape, the majestic mien, and the splendid plumage of this bird, were anxious to present it to their sovereign; and that we read, "once in three years came the navy of Tarshish, bringing gold, and silver, ivory, and apes, and peacocks."

It is probable, that as the pheasant owes her name to the Phasis, a river of Colchis, on the banks of which 
she first attracted attention, the name of the peacock was derived in the same manner. It is everywhere called by the ancients "the bird of Media," or Persia, in which the land of Cush, or Cuth, was situate, because it came originally from that region.

In Greece, and in the Lesser Asia, the peacock was long held in high estimation, and frequently purchased by the affluent at a very high price. In the age of Pericles, a person made a great fortune at Athens by rearing these birds, and exhibiting them to the public ; and many flocked to the sight from the remotest parts of the country. Alexander was so struck, it is said, with astonishment on beholding these birds on the banks of the Indus, and so filled with admiration at their beauty, that he commanded that any person should be severely punished who killed one of them. The voice of the peacock is in strange contrast with its gorgeous array; it is, in fact, a shrill and repulsive scream.

There is generally some drawback to what is thought very beautiful; and the legs of the peacock are often considered unsightly; yet these are, doubtless, best adapted to its circumstances. A singular story is told of one of these birds, which shows its strength. It was a fine and full-grown one, and was observed on a halffinished haystack in the Wottingham meadows. The 
owner of the stack did not like the peacock to remain there, and sent up his son, a little boy, to drive him down. He, in so doing, took hold of the bird's legs, which the peacock no sooner found, than it spread out its wings, and flew away, carrying the boy with it to a considerable distance, unhurt and undismayed. 


\section{THE GOLDEN EAGLE.}

IT might be supposed, from the name given to this bird, that its appearance resembled the most precious of metals, but this does not exactly accord with the fact. The descriptions given of it by naturalists are various. Latham says, that the head and neck are deep brown; Fleming affirms, that the acuminated feathers on the head and neck are a bright rust-colour, and the rest of the plumage dusky brown; while Buffon asserts, that the plumage is at first white, then faint yellow, and that afterwards it becomes a bright copper colour. Still there are cases in which the name is not inapplicable. Mr. Perkins, of Lee, in Kent, possessed an eagle having the peculiar shade of russet yellow which gold when alloyed with copper exhibits; so that the feathers looked as if they had been powdered with gold dust. Others have been observed as presenting a similar appearance. White varieties of the golden eagle, as it is called, have also been seen and recorded.

In times far distant it was said, "Doth the eagle 
mount up at thy command, and make her nest on high ? She dwelleth and abideth on the rock, upon the crag of the rock, and the strong place. From thence she seeketh the prey, and her eyes behold afar off," Job xxxix. 27-29. The nest made by this bird is, in fact, a collection of strong sticks, laid on the highest and most inaccessible parts of rocks, and requiring a space of several square feet. Hence it has been said by one of our poets :

"The tawny eagle seats his callow brood

High on the cliff, and feasts his young with blood:

On Snowdon's rocks, or Orkney's wide domain,

Whose beetling cliffs o'erhang the western main,

The royal bird his lonely kingdom forms

Amidst the gathering clouds and sullen storms;

Through the wide waste of air he darts his sight,

And holds his sounding pinions poised for flight;

With cruel eye premeditates the war,

And marks his destined victim from afar.

Descending in a whirlwind to the ground,

His pinions, like a rush of waters, sound;

The fairest of the fold he bears away,

And to his nest compels the struggling prey :

He scorns the game by meanest hunters tore,

And dips his talons in no vulgar gore."

The range of the eagle is, however, very extensive : not only is it found in various parts of the United Kingdom, particularly in Scotland, but in America, from the temperate to the arctic regions, always preferring a mountainous country; in North Africa, and Asia Minor; 
in the Alps, the Pyrenees, and the forests of Fontainbleau. In some parts, successive generations have observed pairs nestling on the same cliffs.

The attention of the parent bird to her eaglets has often been noticed. Sir Humphrey Davy had an opportunity of witnessing the instructions given, and has thus stated the fact :

"I once saw a very interesting sight above one of the crags of Ben Nevis, as I was going, on the 20th of dugust, in the pursuit of black game. Two parent eagles were teaching their offspring, two young birds, the manœuvres of flight. They began by rising from the top of a mountain, in the eye of the sun. It was about mid-day, and bright for this climate. They at first made small circles, and the young birds imitated them. They paused on their wings, waiting till they had made their first flight, and then took a second and larger gyration, always rising towards the sun, and enlarging their circle of fight, so as to make a gradually extending spiral. The young ones still slowly followed, apparently flying better as they mounted; and they continued this sublime kind of exercise, always rising, till they became mere points in the air, and the young ones were lost, and afterwards their parents, to our aching sight." 


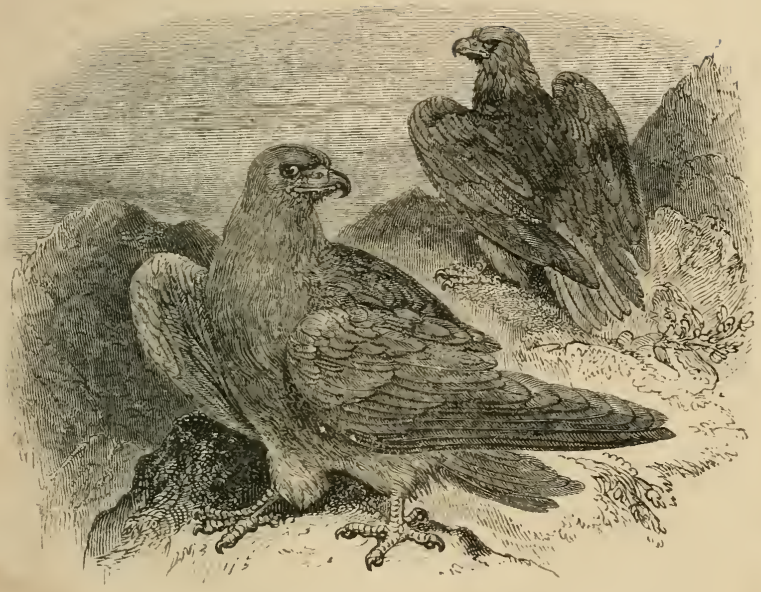

GOLDEN EAGLE. 
It is hoped that the youthful reader of this volume, loves and studies the Bible - the word of the God of eternal truth; and if so, the language of Moses will be at once recalled: "The Lord's portion is his people; Jacob is the lot of his inheritance. He found him in a desert land, and in the waste howling wilderness; he led him about, he instructed him, he kept him as the apple of his eye, As an eagle stirreth up her nest, fluttereth over her young, spreadeth abroad her wings, taketh them, beareth them on her wings: so the Lord alone did lead him, and there was no strange god with him," Deut. xxxii. 9-12. Should indifference to the value of the Scriptures be unhappily felt, let it be remembered, that it indicates the carnality of mind which is enmity against God, and which must be counteracted by his grace, if we would share the privileges of the true " circumcision, which worship God in the spirit, and rejoice in Christ Jesus, and have no confidence in the flesh." What a beautiful emblem have we of the Divine care, in that of the eagle for her young!

This bird may be frequently observed in some parts of the kingdom. One of these is Lochlee, lying in a singular basin, between two perpendicular cliffs on the north, and high and precipitous mountains on the south, at the head of the North Esk in Forfarshire. A pair 
of eagles dwell on each side, so that three may sometimes be seen at the same time in the air; but the dwellers in the inaccessible cliffs on the north seem to bear rule; for the south ones do not venture to be in the valley while these are on the wing. The pair, though they drive off their young, and every creature but man, whose haunts they shun, are closely associated together: when one is seen for any length of time, the other is sure not to be far distant; and the one may often be observed flying low, and beating the bushes, while the other floats high in the air, in order to pounce on the frightened prey.

The flight of the golden eagle is very majestic and powerful. It seldom feeds on anything it finds dead; on fish, or carrion: but from its great strength, it preys easily on fawns, lambs, hares, and other game. Two facts are mentioned by Montagu respecting it, which occurred on the Western Highlands of Scotland. He was sporting in the neighbourhood of Ben Lomond, on the summit of the lesser mountains that form its base, when a red grouse was wounded, and flew with difficulty eighty or a hundred paces. An eagle, apparently of this species, perceiving the laborious flight of the wounded bird, descended with rapid wing from the adjacent lofty cliffs, before the party, of which Montagu 
was one, had time to reload their guns, and in defiance of their shouts, carried off her prey. In another case, an old black cock was sprung, when an eagle, which must have been on a neighbouring rock unperceived, instantly pursued it across the glen, the breadth of which was at least two miles. The eagle made several pounces in view, without success; but as there was neither wood nor cover on the opposite mountains sufficient to conceal so large a bird as a black grouse, he doubtless forfeited his life to the merciless tyrant of the rocks.

It is said that eagles have the power of bearing for a long time abstinence from food: thus, one belonging to a gentleman of Conway, in Carnarvonshire, was neglected by the servants, and kept for three weeks without any sustenance whatever. These birds are also described as being very long-lived. One is stated to have lived in confinement, at Vienna, for a hundred and four years. Two golden eagles, kept by Mr. Selby, appeared untameable in disposition; their fierceness remaining undiminished through years of confinement. They did not exhibit any partiality even for the person who constantly attended and fed them, but were as ready to attack him as a stranger.

Some years ago, a gentleman, residing in the south 
of Scotland, had a tame eagle, which the keeper one day, very injudiciously, thought proper to lash with a horsewhip for some petty fault. About a week afterwards, the man chanced to stoop within reach of its chain; when the enraged bird, recollecting the late insult, flew in his face so furiously and violently, that he was much wounded, but happily, driven so far back by the blow, as to be out of all further danger. The family alarmed by the screams of the eagle, found the offender lying at some distance in a fearful plight, while the bird was pacing and crying in a manner equally threatening and majestic. It was even dreaded that the eagle might break loose in the violence of its rage, which it did just as they withdrew, and escaped.

An eagle, which excited great interest, was some years ago in the Garden of Plants, at Paris. It was taken in the forest of Fontainbleau, in a fox-trap, the spring of which broke its claws, which rendered a painful operation necessary; but, though the cure was tedious, the eagle displayed great patience. Its head only was at liberty during the operation, but it did not oppose the dressing of the wound, from which several splinters were taken; nor did it attempt to disturb the operations which the fracture required. Swathed in a napkin, and laid on one side, the eagle passed the whole night on 
straw without the least motion; and the next day, when all the bandages were unwrapped, lodged itself on a screen, where it remained twelve hours, without once resting on its unsound foot. Its windows were open all the time, but it made no attempt to escape. It refused all nourishment until the thirteenth day of its captivity, when it tried its appetite on a rabbit, seizing it with its uninjured claw, and killing it with a stroke of its beak, between the head and the first vertebra of the neck; and after having devoured it, the eagle resumed its usual place on the screen, from whence it stirred no more until the twenty-first day after the accident. At that time it began to try the wounded limb, and without in the least deranging the ligature by which it was bound, regained the use of it by moderate exercise. Many a parent who has an invalid child, would have far less trouble, in the exercise of kind and watchful attention, were the object of so much care as truly patient as this eagle. The sufferer too, would enjoy advantages which the wayward and irritable never know. 


\section{THE WHITE-TAILED EAGLE.}

THE white-tailed eagle is much more common, as a species, than the golden eagle, and it may frequently be seen on some parts of our coast. Dwelling in the high rocks and cliffs that orerhang the ocean, it looks out eagerly for prey : when hungry, it will seize either fowl or fish; it will feed also on seals and renison, and has sometimes been killed in forests and deer-parks. It lays two eggs. Its young are at first corered with a soiled white down, having very large beaks and claws, and are driven away by the parent birds as soon as they are able to provide for themselves. The white-tailed eagle frequents Denmark, Sweden, and the west coast of Norway; proceeding as far north from thence as Iceland and Greenland. Returning from high northern latitudes as the season advances, this species is much more numerous in winter than in summer.

A pair of these birds had long inhabited a lofty tree on the coast of Ireland, and, perhaps from age, seized anything they could find, to the great annoyance of the 
neighbouring peasants. Many persons wished to stop their plunder, but like not a few in other circumstances, they were not remarkable for promptitude; and besides, everybody respected the eagles. The gardener of one gentleman, however, had orders to load his musket, and to fire on the female bird the first time she ventured to intrude among the goslings, or to pursue some unfortunate chicken. But she was a magnificent bird-far larger than her husband-and Peter's heart failed him. "Look at her!" he said, as she sailed in the distance; "look at her, master! I remember that ould lass ever since I was the height of a raspberry plant; and I couldn't find it in my heart to hurt a feather of her wing, the craythur! What signifies a dozen of goslings to such a bird as that? Won't there be plenty o' geese of all sorts when she's gone? But my father before me used to say, 'Peter,' says he, ' mark my words, them 'ill be the last o' the rale ancient Irish eagles that 'ill ever settle in the barony; for they 've a mortal hatred to new fashions:' but as to killing her, I'd as soon think o' killing the priest!"

Vain was it, then, to expect relief from Peter; but as goslings were again destroyed, and still more, as the rapacious bird took a fancy to a beautiful pea-hen that was brooding over her eggs in a retired copse, it was 
determined that, as the killing of the birds seemed out of the question, the tree should be cut down, and then it was supposed that the eagles would quit the neighbourhood altogether. This expectation proved to be correct. The eagles returned at night, but the tree, on the topmost and blighted boughs of which their nest had so long rested, was now lying on the ground. What could then be done? They made some circles about it, uttering shrill and plaintive cries, and then they departed to find a new abode; it was thought, in one of the islet bays, with which that part of the coast abounds.

That children have been carried away by eagles appears to be well attested. A white-tailed eagle built its nest on Tintholn, in the Feroe islands, and one day darted down on a child which was lying at a little distance from its mother, and bore it away. The rock where the nest was constructed was so steep towards the summit, that the most courageous and experienced birdcatchers had never ventured to climb it; but a mother's love was not to be thus baffled: the agonised parent encountered the task, and reached the top, but unhappily too late; her little one was there, but it was dead, and partly devoured.

Another case of the same kind had happily a different 
issue. A native of the isle of Skye, named Neil, was left, when an infant, by his mother in the field, " not far," says Martin, "from the houses on the north side of Loch Portrie," when an eagle came and carried him away in its talons, as far as the south side of the loch, and there laid him on the ground. Some people tending sheep, hearing the infant cry, immediately ran to his rescue, found him providentially untouched by the eagle, and bore him home to his mother. " $\mathrm{He}$ is still living," says Martin, in 1716, " in that parish, and by reason of this accident is distinguished among his neighbours by the surname of Eagle."

The following is also a remarkable tale. A peasant, with his wife and children, had taken up his summer quarters in a small cabin or shed, near Briançon, and was feeding his flocks among the mountain herbage which overhangs the Durance. The eldest child was an idiot, about eight years of age; the second, five years old, suffered from another calamity, that of dumbness; and the youngest was an infant. One morning the latter was left in the charge of his brothers, and all had rambled to some distance from the cabin before they were missed. At length, the mother, whe went forth to seek the wanderers, discovered the two elder, but the infant was gone. 
The idiot appeared to be full of delight, and the dumb child greatly alarmed and terrified; but in vain did the parent, in her anguish, endeavour to ascertain what had befallen her lost babe. Again and again did she observe the movements of her two children: the dumb boy appeared almost bereft of his senses, while the idiot danced about, laughed, and seemed by his gesticulations to imitate the action of one who had caught up something of which he was fond, and hugged it to his heart; but no solution of the mystery was given by the antics of the one, or the fright of the other. One slight consolation, however, arose-it was in the thought that some acquaintance had fallen in with the children, and taken away the infant; but the day and night wore away without any tidings of its state.

On the morrow the parents renewed their search, when, as an eagle was seen to fly orer their heads, the antics of the idiot were resumed, and the dumb boy clung to his father, and shrieked aloud with anguish and terror. Now the fearful fact burst on their minds, that the infant had been carried off by some bird of prey, and that the half-witted child was delighted at the removal of one of whom he was jealous : and so it proved. On the morning of their loss, an Alpine hunter had been watching near an eagle's nest, in the hope of shoot- 
ing the bird on her return to the eyrie, and, at length, he beheld her advancing towards the rock behind which he was concealed. On a nearer approach, he observed, to his indescribable horror, an infant in her grasp, and heard with anguish its bitter cries. In a moment he resolved to fire at the eagle the instant she alighted, and rather to kill the child than to leave it for a prey to the ravenous bird. That instant came: with a silent prayer and a steady aim he poised his rifle, and, most providentially, the ball pierced the head or heart of the eagle, and immediately this hunter,

"Whose joy was in the wilderness, to breathe The difficult air of the iced mountain's top,"

found a far higher delight fill his bosom in snatching the child from the eagle's nest, and bearing it securely away. It was wounded by the talons of the bird, but not mortally; and in less than twenty-four hours after it was first missed, he had the high satisfaction of restoring it to its mother's arms.

Notwithstanding the extreme boldness of the whitetailed eagle, it does not dare to contend with a fox or a dog in its natural wild state. Singularly enough, an eagle and a fox were, on one occasion, observed to be regaling themselves on the carcase of a goat that had fallen down a precipice in the Highlands of Scotland. 
The latter frequently compelled the former to desist, and retreat a little; but it was not so much alarmed as to forbid its return; and occasionally it threw itself into bold and picturesque attitudes of defence, erecting all its feathers, and spreading to the full the wings and the tail. 


\section{THE PEREGRINE FALCON.}

THIS bird, more numerous in Scotland than England, builds its nest on high rocks : its name, Peregrine, is given from its migratory habits on various parts of the coast. In the Isle of Wight these falcons breed annually near the Needles, and destroy many of the puffins and razor-bills in the neighbourhood. In the vicinity of St.Abb's Head, an eyrie has been observed as long established: from hence a gentleman usually obtained his cast of hawks, for each of which he gave a guinea to those who encountered the danger of scaling the precipice. It is said, that numbers of the peregrine falcon reside temporarily on Westminster Abbey, and make sad havoc among the tame pigeons in the neighbourhood.

This bird is associated with one of the old English sports. There seems to have been a passion for hawking among all the nations that owned a Scandinavian origin; and perhaps none exceeded our forefathers in its intensity. For centuries it was satirized and denounced 
by some; but the amusement was still cherished, and it was even thought it would be practised to the end of the world. A king of Kent begged from a friend abroad two falcons of "such skill and courage, as to attack cranes willingly, and, seizing them, throw them on the ground." He says, " he makes this request because there were few hawks of that kind in Kent." There are instances, too, of Saxons leaving hawks by will: and one of the kings of the Heptarchy liberated some lands "from those who carried with them hawks or falcons, horses or dogs."

Falconry appears to have been in high estimation at the court of the king of Wales, for there were only three officers of his household above the master of the hawks : he occupied the fourth place from the sovereign at the royal table, but was not permitted to drink more than three times, lest he should be intoxicated, and neglect his birds. The discharge of his duty in this respect was the chief object at which he aimed, and one attended, according to popular opinion, with great honour. Not only had he the management of the hawks, and the direction of the people employed in this sport, but when he had been very successful, the king was obliged, by law and custom, to rise up to receire him when he entered, and even, on some occasions, to hold his stirrup. 


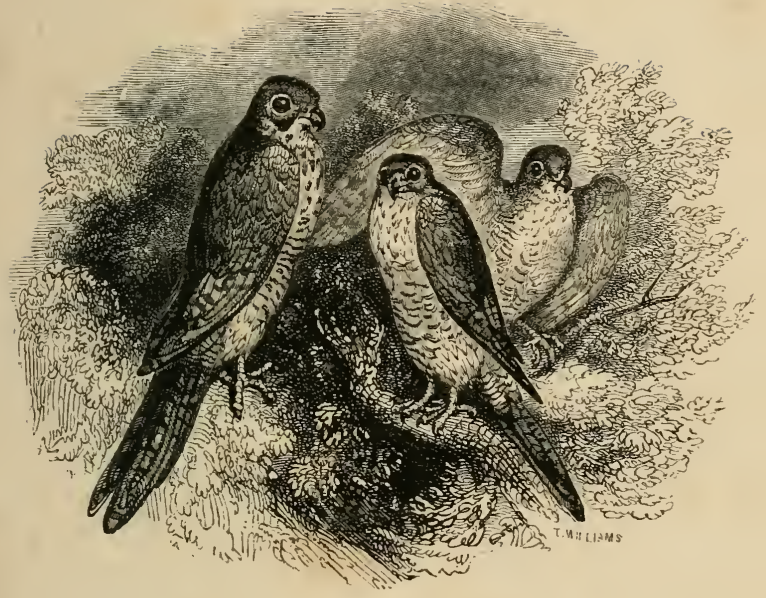

THE PEREGRINE FALCON. 
Ethelstan made North Wales furnish him not only with as many dogs as he chose, "whose scent-pursuing noses might explore the haunts and coverts of the deer," but "birds who knew how to hunt others along the sky." The finest and largest falcons, however, came from Norway. Hawking seems to have been pursued among the Saxons almost as it was in later times: many of their kings, like Alfred, were expert falconers. But it was the Normans who attached to falconry the greatest importance, and gave almost as minute and careful instructions for training and preserving the hawk, as for tending and instructing the heir of the family. An expensive diet was considered necessary. All treatises on the subject require for this bird the purest water and the freshest raw meat - two articles not always to be found in a baron's castle, where salted sheep were the chief winter provisions, and where muddy ale and beer were more plentiful than spring-water.

In the middle ages the price of a good falcon was very high. In the early part of the reign of Edward III. the king of Scotland sent him a falcon gentil, which he graciously received, and gave the falconer who brought it forty shillings, a sum equal to forty or fifty pounds in the present day. At a much later period the prices of these favourite birds appear to have been enormous. 
The goshawk and tassel-hawk were often sold for one hundred marks in the days of James I ; and Sir Thomas Monson is reported to have given, in the same reign, no less than one thousand pounds for a pair of hawks.

To this expense was added that of a numerous "menye," under the direction of the chief falconer, to attend to the different departments of the mews: for these birds had to be supplied with fresh water several times every day; to be taken out, too, and flown; and to be fed continually. Nor was this all, for to break in a hawk it must be kept waking the whole night; and thus the falconer, in addition to his usual labour, had not unfrequently to keep watch until dawn, with the refractory bird on his hand.

Gaily bedecked, indeed, were these beautiful birds when transferred from their perch to the glove, whether to fly at the game, or merely to be borne on solemn or festive occasions, as appendages of high rank. There was the collar, often of fine enamelled work, or the most delicate gold filigree; the hood, of silk knitting, sometimes exquisitely embroidered; the bells suspended from the leathern rings round each leg, which were called bewits, most frequently of neatly wrought silver. The glove, too, on which the bird sate, was of richly embroidered white leather, sometimes even adorned with jewels 
-made to reach no higher than the wrist on the inside of the hand, while on the outside it covered the arm nearly to the elbow, that the bird, at the word of command, might retreat from the wrist up the arm, and thus leave the hand at liberty.

When the falcon was carried abroad for sport, the tnin straps of leather attached to the legs, by which she was held on the hand, called jesses, were made shorter, that they might not impede her flight; and, unless she were a well-practised bird, a long silken thread, called a creance, was attached to the bewits, by means of which she could soar as high as was necessary, and be again reclaimed. The hawk was commonly hooded until the game was sprung; the covering was then removed, the creance was unwound, and the bird cast off the hand. A well-trained hawk was always expected to bring down the best bird, uninjured either by her strong beak or sharp talons; the prey was then taken from her, and she was returned to her station on the wrist, until another covey rose, when she was again cast off.

Walton's Falconer says : — "In the air, my noble, generous falcon ascends to such a height as the dull eyes of beasts and fish are not able to reach to - their bodies are too gross for such high elevation - but from which height I can make her descend by a word from 
my mouth, which she both knows and obeys; to accept of meat from my hand, to own me for her master, to go home with me, and be willing the next day to afford me like recreation."

Sir J. Sebright says : - "The village of Falconswaerd, near Bois-le-Duc, in Holland, has for many years furnished falconers to the rest of Europe. I have known many falconers in England, and in the service of different princes on the continent; but I never met with one of them who was not a native of Falconswaerd. It has been the practice of these sober and industrious men to stay with their employers during the season for hawking, and to pass the remainder of the year with their families at home. John Pells, now in the service of my friend, John Dawson Downes, Esq. of Old Gunton Hill, Suffolk, and who also manages the heron-hawks kept by subscription in Norfolk, is, I believe, the only efficient falconer by profession now remaining; all the others whom I remember are either dead or worn out, and there has been no inducement to younger men to follow the employment of their forefathers."

The Duke of St. Albans, as grand falconer of England, had, till lately, an establishment for training hawks not far from Colchester; he also gave, on several occasions, a specimen of their skill and power. But although 
falconry had such a despotic sway for many ages, it is now a question whether there is a single reclaimed foreign hawk in the western part of the kingdom. There may, however, be a few English hawks annually trained in the neighbourhood of Bridport, in Dorsetshire, for the taking of landrails in the hemp or flax fields near that town, in which, during some summers, they are very plentiful. 


\section{THE JAY.}

THE rich colouring in the bastard wing and greater coverts belongs exclusively to this one species of bird. The blue, the black, and the white, are here most exquisitely blended. The eye, therefore, dwells on this bird with peculiar pleasure. These brilliant colours are however possessed, as is the case with other birds, prior to the first moulting; hence the male and female are so much alike that they are not easily distinguished from one another.

The jay is found in considerable numbers in most of the wooded parts of this country, but they seldom congregate together. The nest of the magpie and the crow may be observed near the tops of trees, but here the dwelling of the jay is never seen. In the lower branches of the oak, or the woodbine mantling round the hazel, it finds an abode. Like some other birds, as the jackdaw, the rook, and the pheasant, it feeds voraciously on the acorn. In pea and cherry time it becomes remark- 


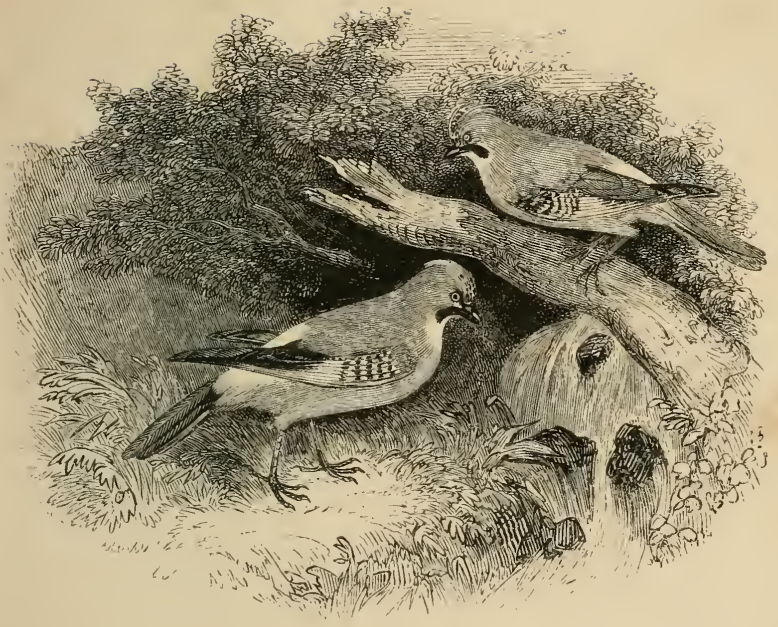

THE JAI. 
ably daring and adventurous, and consequently, many of them become the prey of watchful gardeners.

When the snows of winter have fairly set in, and acorns cannot be found among the fallen leaves of the woods, the jay may be noticed flitting from hedge to hedge in the neighbourhood of pea and bean stacks, and clinging to their sides in quest of uncovered pods.

When spring returns, the lover of natural scenery, and of the living objects by which it is adorned, may sometimes hear a profusion of imitative notes, now hoarse and sonorous, now lowered and subdued, and composed of modulations almost approaching to those of song. They are emitted by a small party of jays, that assemble merrily before they depart in pairs, to choose a place for building their nests and hatching their young. It is only at this time that they appear disposed to be social : at other times the jay is a solitary wandering bird, and does not allow its young to associate with it, after they are able to provide for themselves. 


\section{THE TITHOUSE.}

ThE note of the black-headed titmouse, in spring, exactly resembles the setting of a saw. The sound ceases when the bird has a nest; and it appears to foretel rain. The crested titmouse is found only in the forests of Scotland. The elegant bearded titmouse appears amidst the reeds on the banks of the Thames, feeding on insects, but chiefly on the seeds of marsh plants. Of these birds there are also four other species.

They are lively, active, and courageous: they flit from tree to tree; they hop from branch to branch, calling to each other; they hang upon the bark; they poise themselves against the walls; they hook themselves on the trunks of trees, and are suspended in all forms, often with the head downwards, in order to examine every little crevice, and to search out caterpillars, insects, or their eggs. They live also on grain; but instead of breaking it with their bill, like linnets and goldfinches, almost all of them hold it fixed under their little claws, and pierce it with strokes of the beak. 
They pierce in the same way nuts and almonds. In general all the titmouse tribe, though rather fierce, love the company of their brethren, and keep in families. When separated by accident, they call mutually to each other, and are soon rejoined in society. They lay many eggs ; most species making their nests in the hole of a tree, but one in a round ball appended to a branch, and of a size disproportioned to so small a bird.

Sometimes the titmouse will feed on walnuts, attacking and devouring them as they grow on the tree, and while, from their not being fully ripe, the green outside husk remains. Of course, it especially likes a tree, which is sometimes found bearing nuts, the shells of which consist of a soft texture, easily pervious to its little beak. In such instances it commences its attack at the soft or imperfect apex of the shell, and pecks out the kernel as far as its bill can possibly reach. The entire kernel has been frequently known to be completely scooped out by the titmouse, before the nut was ripe enough to fall from the tree. On one large tree, with a good crop, scarcely a walnut remained which had not been assailed by these birds, and more or less eaten. 


\section{THE GULL.}

ON various parts of the British coast this bird is constantly found. It breeds on the ledges of rocks close to the sea-shore, sometimes not far above the water. Hundreds have been observed sitting on their nests in an island off St. David's, the nests being made of seaweeds, and placed nearly together, about fourteen feet from the beach. When disturbed they are very clamorous, and not much alarmed by the sportsman's gun. They are frequently seen in winter, at a considerable distance from the coast, and they flock with rooks in the severe weather.

The writer remembers a gentleman, well known as a literary character, telling him that when a schoolboy, on one part of the Irish coast, he and his companions often dared one another to feats of extreme peril. Among these was that of one being suspended over the cliffs, by means of a rope, or if this were wanting, by pocket-handkerchiefs fastened together, in order to take the eggs of the birds that build in the rocks. We 


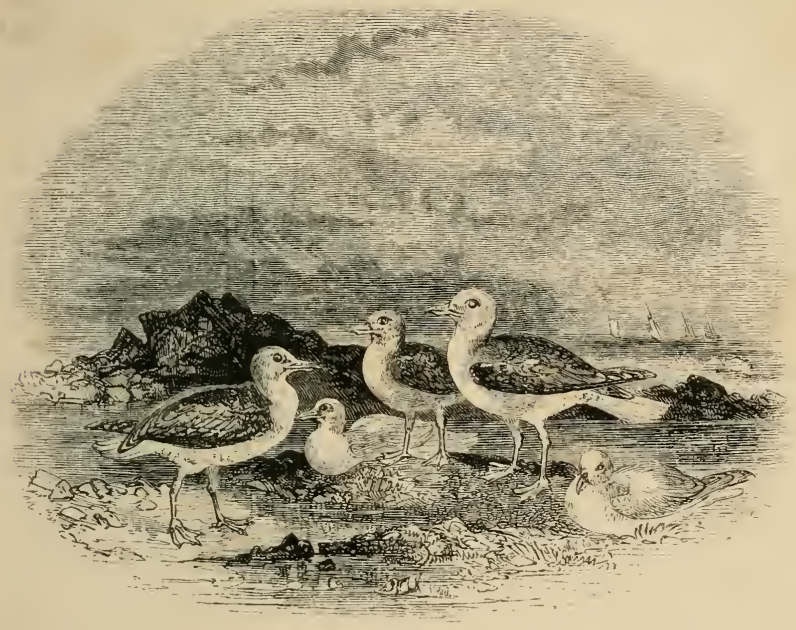

THE GULL 
tremble instinctively as we think of the hardihood so wantonly and foolishly displayed. What would have been the feelings of the rest, if one of these frail dependencies had given way, and, while the body had fallen mangled on the beach, the spirit had been hurried into the presence of God! And yet such a catastrophe might easily have occurred, and would doubtless have arisen, but for the interposition of Him, whose goodness was never recognized amidst the thoughtless hilarity of youthful days.

In the hazardous enterprise of taking the young, and the eggs of the birds that dwell on their rocky coasts, the inhabitants of the Hebrides, the Feroe, and other northern islands, frequently engage to earn their subsistence. Sometimes they provide themselves with a long rope, having a strong stick about three feet long attached to the end. One of them then fastens one end about his waist and between his legs, and supporting himself partly by the stick, is lowered down by several others. A small line attached to his body enables him to give signals that he may be raised, lowered, or shifted from place to place. Imagine a man thus dangling in mid-air, and little appears between him and death; but his peril will be still more apparent when it is remembered that, as his position is changed, fragments of 
the rock are detached, and fall about his head, which requires to be protected by a strong thick cap, and even then is not safe from the larger masses that descend.

Remarkable indeed is the dexterity of these fowlers. Placing their feet against the front of the rock, often two hundred fathoms in height, they will dart themselves to a considerable distance from it, mark the place where the birds nestle, and discharge their pieces into their haunts. When the birds lodge in deep recesses, the fowlers will alight, detach themselves from the rope, collect their booty at their leisure, fasten it to their girdles, and resume their scats.

We are indebted for the following facts to a valuable work on Birds, by the Rev. E. Stanley. Many birdcatchers go on these expeditions without any companion to hold the rope or assist them. It was on such a solitary excursion, that a man, having fastened his rope to a stake on the top, let himself down far below; and, in his ardour for collecting birds and eggs, followed the course of a ledge, beneath a mass of overhanging rock ; unfortunately he had omitted to take the usual precaution of tying the rope round his body, but held it carelessly in his hand, when, in a luckless moment, as he was busily engaged in pillaging a nest, it slipped from his grasp, and, after swinging backwards and forwards 
three or four times, without coming within his reach, at last became stationary over the ledge of the projecting rock, leaving the bird-catcher apparently without a chance of escape; for to ascend the precipice without a rope was impossible, and no one was near to hear his cries, or to afford him help. What was to be done? Death stared him in the face. After a few minutes' pause he made up his mind. By a desperate leap he might regain the rope; but if he failed-and, at the distance at which it hung, the chances were against him - his death was certain amidst the pointed crags ready to receive him, over which the waves were dashing far, far below. Collecting, therefore, all his strength, with outstretched arms he sprang from the rock, and lived to tell the tale - for the rope was caught !

Another fact occurred at St. Kilda; where, amongst other modes of catching the sea-fowl, that of setting gins or nooses is adopted. They are fixed in various places frequented by the birds. In one of these, set upon a ledge, a hundred and twenty feet above the sea, a birdcatcher entangled his foot, and not being at the moment aware of it, was, on moving onwards, tripped up, and precipitated over the rock, where he hung suspended. $\mathrm{He}$, too, as in the preceding case had no companion; and, to add to his misfortune, darkness was at hand, 
leaving little prospect of his being discovered before morning. In vain he exerted himself to bend upwards, so as to reach the noose or grapple the rock. After a few fruitless efforts, his strength was exhausted, and in this dreadful situation, expecting, moreover, that the noose might give way every instant, did he pass a long night. At early dawn, happily, his shouts were heard by a neighbour, who rescued him from his perilous suspension. 


\section{THE SWAN.}

ON the water of large estates in this country, swans are kept for the sake of ornament. Wordsworth has thus described the form and movements of this bird, which is so attractive to the eye wherever it is beheld:-

Fair is the swan, whose majesty prevailing

O'er breezeless water, on Lacarno's lake,

Bears him on, while proudly sailing

He leaves behind a moon-illumined wake:

Behold! the mantling spirit of reserve

Fashions his neck into a goodly curve;

An arch thrown back between luxuriant wings

Of whitest garniture, like fir-tree boughs, T'o which, on some unruffled morning, clings

A flaky weight of winter's purest snows !

Behold! as with a gashing impulse, heaves

That downy prow, and softly cleaves

The mirror of the crystal flood,

Vanish inverted hill, and shadowy wood, And pendant rocks, where'er, in gliding state, Winds the mute creature without visible mate Or rival, save the Queen of the Night, Showering down a silver light

From heaven, upon her chosen favourite. 
The plumage is of an ash-colour till the second year, after which it becomes pure white. The female builds her nest of water-plants, reeds, long grass, and sticks, in some retired bank of a river or lake, and her eggs are much larger than those of a goose. The young are called cygnets: as soon as they can fly their quillfeathers are clipped; and this is repeated every year.

The swan lives to a great age; sometimes, it is said, to a century or more. Though a powerful enemy when attacked, it is not an offensive bird. A few years ago a very fine swan was drowned in Trentham Pool, the seat of the Marquess of Stafford, by a pike driving at its bill: they were of equal strength, and the bird and the fish alike perished.

Each family of swans on the river Thames has its own district; and if its limits are encroached upon by others, a pursuit immediately takes place, and the offenders are driven off : in other cases they live in perfect harmony. The male is very attentive to his mate, and the parent birds take great care of the cygnets. Where the stream is strong, the old swan will sink herself sufficiently low to bring her back on a level with the water, when the young ones will get upon it, and in this manner are conveyed to the other side of the river, or into stiller water. 


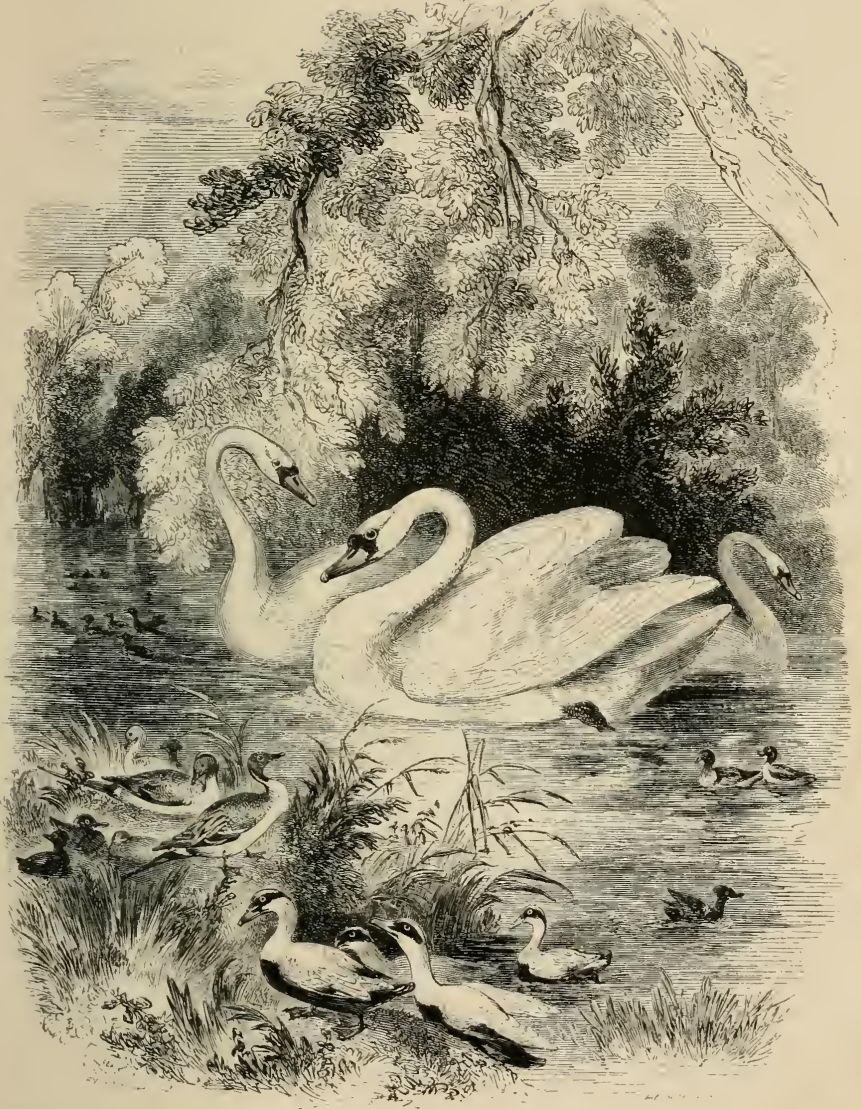





\section{THE SPARROW-HAWK.}

THIs is a very common species in most of the wooded or enclosed parts of the kingdom, but in the more champaign parts it is less frequently observed. Seldom making a nest, it generally takes possession of one which a crow has left. The female is very bold, destroying largely game and young poultry, flying low for this purpose; snatching up a chick from a brood in an instant, and as quickly out of sight.

A pair of sparrow-hawks bred in an old crow's nest on a low beech in Selborne Hanger; and as their brood, which was numerous, began to grow up, they became so daring and ravenous, as to be a terror to all the dames in the village who had charge of either ducklings or chickens. A boy climbed up into a tree, and found the young so fully fledged, that they all escaped, but he observed also that the larder was well stored with provisions: he brought down some half-devoured, and a young blackbird, jay, and house-martin, all clean picked. The fact was, that the old birds had made sad 
havoc for some days among the newly flown swallows and martins, which having but lately left their nests, had not acquired sufficient power or command of wing to defy their enemies.

One family is described as having a pet sparrowhawk. Harry, as he was called, became tolerably tame a few weeks after his arrival, would take food from the hand, and follow them about, even in the house. Though the kitchen was not at other times his favourite apartment, he always visited it when meat was roasting. He was fed on dead birds and mice, when these could be procured. Cruel, as it certainly is, to expose a live bird to the torture of fear, sometimes one was given him: then the poor little creature did not at first attempt to stir, but crouched down with its breast close to the ground; after a few minutes it would move, when Harry, who had been standing perfectly still, would give it a pat with its foot to make it quiet. If two or three persons were standing around, some minutes would pass in this way, and, at last, Harry would give one instantaneous peck on the head of the bird, and it was dead. Then, but never till then, did he commence his meal, always eating in the same manner, with great nicety and neatness, and leaving only the strong feathers of the wings and tail. 
One of his favourite haunts was under a large Portugal laurel, which was so thick, close to the ground, that nothing could grow beneath, but it was the resort of an immense number of birds, and here many of them built their nests. Hawks generally perch as high as possible, and Harry was fond of the topmost branch of a large willow, where he swung with the breeze; curiosity was, therefore, excited to ascertain what attracted him to the bare earth under the laurel, and it was supposed that he now and then caught a young nestling which fell from the nest. Still the observers were not satisfied, as they found that he took his station there during the whole summer, long after the young birds had flown away, and at last they discovered, under a plant near the laurel, the wing and tail-feathers of a full-grown bird, evidently the remains of his repast. The reason of his preferring the spot was now obvious.

Harry never attempted to touch a young chicken or duck, but used to strut about the yard where the poultry were kept, without being feared or regarded. During a severe winter, he walked into their house with the pigeons at night, slept in their dwelling, and came out with them when the door of the trap was let down in the morning; and yet, though there was a numerous flock of old and young birds, no one was ever missed. 
With a dog kept in a kennel, however, he was always at war: perching on the edge of the pan which contained the animal's food, and often preventing him from eating, though he himself took little.

It was long a matter of wonder why he used to perch on the top of a hand-glass, when the piano-forte was in use, sometimes attempting to rest on the window-sill, and at length coming quite into the room. On one occasion he was brought in, and placed on the edge of the instrument, more for the sake of seeing him ruffle his feathers than from any expectation of giving him pleasure; when he stood there for a considerable time, evidently in great delight, and it was with some difficulty he was removed. After this he frequently perched on the handle of a work-basket, or on the instrument, unlike the pigeons, who, familiar as they were with the family, always marched out of the room when the pianoforte was in use, having evidently no liking to the " concord of sweet sounds." 


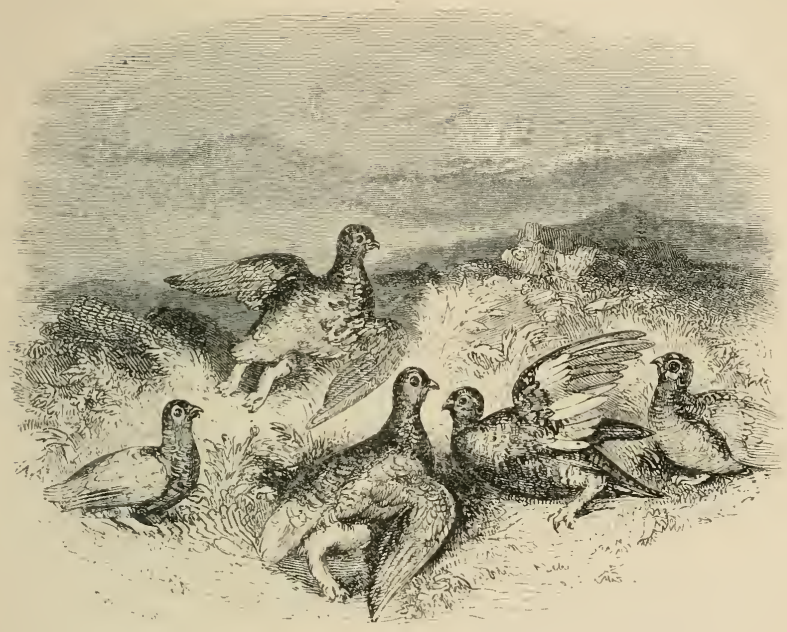

TIIE MOOR FUITI. 


\section{THE MOOR-FOWL.}

This bird, driven to the north by cultivation, is only to be found in the extensive and untilled wastes covered with heath, particularly the situations which are most mountainous. The most southern parts in which moorfowl now appear, are the mountains of Wales; in Yorkshire, and from thence northward on the moorlands they are not uncommon; but they especially abound in the Highlands of Scotland. They are also found on the western islands, and in the mountains and bogs of Ireland, but they seem to be confined to the United Kingdom.

The moor-fowl confine themselves to the open moors, form their nests of a few withered stems, placed carelessly together in a tuft of heath, and feed on the mountain and bog berries. A female was taken alive near Wedhampton, in Wiltshire, many years ago; but it is difficult to say by what accident it was driven so far from its native moors, as the nearest place to this which moor-fowl are known to inhabit, is the south of Wales, 
which is not less than sixty miles distance in a straight line.

The young keep with the parent birds till the approach of winter. In November sometimes thirty or forty flock together; they are then plentiful, but extremely shy, and difficult to be shot. In severe seasons they come lower down the mountains in Scotland, and assemble in great numbers. In 1782 and 1783, it is said three or four thousand assembled. On another occasion, a gentleman who encamped at the source of the Dalmon, at the foot of an immense hill, called Croke Franc, says : "The game on these moors is innumerable. In a mile long, and not half a one broad, I saw at least one thousand brace of moor game." Since then they have been greatly diminished. 


\section{THE PETREL.}

Trus species, called by sailors, "Mother Cary's chicken," resembles a swallow in its general appearance, size, and flight. It is rarely seen on our shores, except in some of the northern islands, where it breeds in the holes of rocks. It makes no nest, but lays one lone egg.

Birds of this kind are sometimes found dead near to the coast, and at others at a distance. One specimen was killed near Bath, and another so far inland as Derbyshire; and hence it has been thought that they sometimes fly across the land, or perhaps are driven inland by the strength of the gales frequently occurring at the season when they have been found. But the cause of the mortality that prevails in different parts, it is difficult to determine.

Petrels live remote from the land except in the breeding season. They are seen in great numbers all over the Atlantic, and thus led one of our poets to say : 
"Swift birds, that skim o'er the stormy deep,

Who steadily onward your journey keep,

Who neither for rest nor for slumber stay,

But press still forward by night or day;

As in your unwearying course ye fly

Beneath the clear and unclouded sky;

Oh ! may we, without delay, like you,

The path of duty and right pursue."

A. celebrated voyager once saw a stream of stormy petrels, from fifty to eighty yards deep, and in breadth three hundred yards or more. They were not scattered, but appeared to be flying as compactly as they could to have the full use of their wings, and they passed on without intermission for an hour and a half, at a rate of swiftness little inferior to that of a pigeon. Their number must have been indeed prodigious : one cannot venture to calculate them.

The petrel, which will frequently follow a ship for many days, probably for the sake of what is thrown overboard, for it will stoop and pick up bits of biscuit and meat, is supposed by sailors to be seen only before stormy weather, and is therefore considered by no means a welcome visitor. It is not, however, peculiar in presaging tempests, as birds of different families have a nicer perception of change in the atmosphere than man. Thus, before rain, swallows more eagerly hawk for flies, and ducks carefully trim their feathers, and 


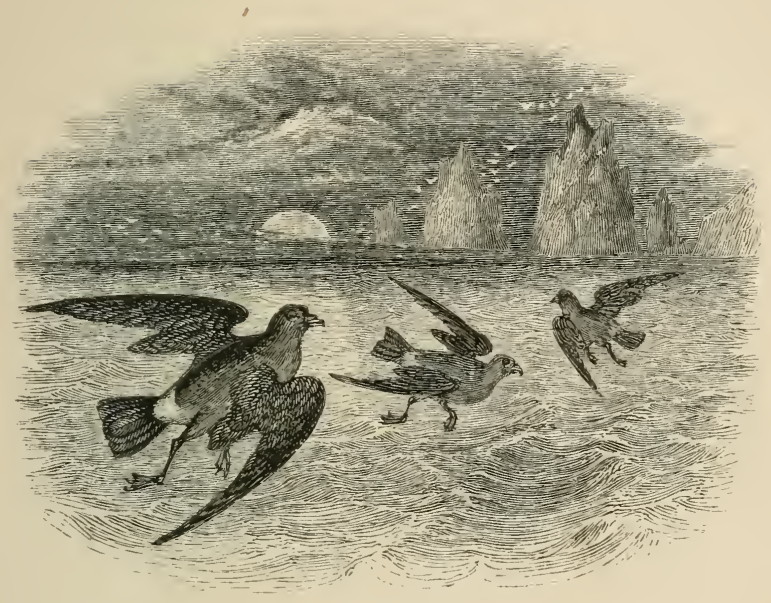

THE PETREL. 
toss water over their backs, to try whether it will run off again without wetting them. Superstitious, indeed, is the sailor who thinks the petrel the cause of a storm ; it might as well be supposed that the swallows and the ducks are the cause of rain.

But though these birds wing their way over the ocean so bravely, they are, in fact, sensible of danger, and make all haste to the nearest shelter. They find, if they can, an island or a rock to shield them from the blast; but failing to do this, they hasten to the first ship they can descry, crowd into her wake and even close under the stern, heedless, apparently, of the rushing surge, so that they can have the vessel between them and the unbroken sweep of the wind. The low wailing note of weet weet, which may be heard during the whole of a stormy and starless night, is, of course, depressing to ignorant and superstitious minds. Such, alas! are those of sailors generally; and though we owe them much, we do but little to promote their welfare. It ought to be otherwise. Two hundred and eighty thousand of these our fellow subjects, passing by unnumbered casualties into an eternity for which multitudes on multitudes of them are utterly unprepared, make a forcible appeal to every Christian's heart. 


\section{THE NIGHTINGALE.}

A MODERN writer says:- " A friend had told me, 'You will find the nightingale a lively sprightly bird, and its song the joyful outpouring of a healthy, hearty, happy individual.' And so indeed it proved. I at once became enamoured of the little songster. Some months afterwards, haring in vain sought to steal upon him in the bushes, which resounded with his melody, I, at length, caught sight of the rusty little warbler in a cage, which furnished his coyness with no concealment. I wondered, with the ancient naturalist, Pliny, that so small and mean a body should supply so loud a voice such a fund of spirit and earnestness."

Coleridge also describes, in glowing terms, his feelings in reference to the largest of British warblers, so deservedly esteemed for the variety and richness of its song, the compass of which is such as to reach through three octaves.

And, hark! the nightingale begins its song,

"Most musical, most melancholy" bird. 
A melancholy bird ! oh! idle thought!

In nature there is nothing melancholy. 'Tis the merry nightingale

That crowds, and hurries, and precipitates, With fast, thick warble, his delicious notes, As he were fearful that an April night

Would be too short for him to utter forth

His love-chaunt, and disburden his full soul of all its music!

And I know a grove Of large extent, hard by a castle huge, Which the great lord inhabits not: and grass, Thin grass, and kingcups grow within the paths;

But never elsewhere in one place I knew So many nightingales; and far and near, In wood and thicket, over the wide grove They answer and provoke each other's song, With skirmishes and capricious passagings, And murmurs musical and swift, jug, jug, And one low piping sound more sweet than all, Stirring the air with such an harmony, That, should you close your eyes, you might almost Forget it was not day! On moonlight bushes, Whose dewy leaflets are but half disclosed, You may perchance behold them on the twigs, Their bright, bright eyes, their eyes both bright and full, Glistening, while many a glowworm in the shade Lights up her love torch.

And oft a moment's space,

What time the moon was lost behind a cloud, Hath heard a pause of silence; till the moon Emerging, hath awaken'd earth and sky With one sensation, and these wakeful birds Have all burst forth in choral minstrelsy, As if some sudden gale had swept at once A hundred airy harps! 
The poet, at the commencement of this beautiful description, alludes to an error often entertained in reference to the nightingale. Strange is it that this lively bird should ever be thought melancholy. Its solitary habits, and its love of the night, have probably given rise to this opinion: but no bird sings when it is sad.

The nightingale is not found north of Shrewsbury in the west, or Doncaster in the east, and is seldom seen in Cornwall or Devonshire. It has been said to be only observed where cowslips grow plentifully, the indications of a damp, cool soil; but this is not correct. Nightingales are very numerous at Colchester, where a cowslip is scarcely to be seen, and the soil is dry and gravelly: they abound in gardens, as well as woods. They have never ventured north of the Tweed. Hence the poet Leyden wrote :-

Sweet bird! how long shall Teviot's maids deplore Thy song, unheard along her woodland shore!

Sir J. Sinclair tried, indeed, to introduce the nightingale into the groves of Scotland. The eggs of robins were exchanged for those of nightingales; the young birds were hatched and brought up by their foster-parents, but they migrated in September, the usual time, and never returned to the place of their birth.

Still, the nightingale is known in many parts of Europe. It is found as far north as Sweden, in the greater 
part of Asia, and also on the banks of the Nile. It has a strong predilection for the spot where its first abode was, and will return from year to year to the same place, until the grove which supplied a shelter is cut down, and even then another station will be chosen as near it as possible.

A modern traveller describes, in pleasing terms, his gratification on hearing some of these songsters. He had wandered out to take a draught of the fresh breeze, perfumed as it was by the thousand aromatic plants that grew wild on the mountains of Andalusia. There he found an inducement to linger much longer than he had anticipated. He had been delighted already during the day's ride, especially after sunset and the commencement of twilight, by the singing of nightingales, which abound in Spain ; and, on this occasion, there were two, perched upon opposite trees. They sang alternately, and evidently waited for each other; the one only commencing some time after the other had finished. Thus they exercised a degree of deference and politeness towards each other not always observed by more reasonable creatures. Their prevailing note was, as usual, that sweet and swelling strain which, beginning in a low whistle, passes from rapid quarers to well-articulated modulations, and grows fuller and fuller for a few 
seconds, until it reaches the pitch of force and melody, thence declining to a close by an equally happy and harmonious gradation. In some cases, two have been heard at night, thus singing against each other; but it was in rivalry rather than in deference.

Nightingales generally return to Germany about the middle of April, near the time the hawthorn begins to show its blossoms; and towards the middle or end of August they prepare for their departure. This they do very quietly, passing on, without noise or confusion, from thicket to thicket towards the end of their journey, so that they are no longer found in that country by the middle of September. In Italy they arrive in the month of March, and about the commencement of November they begin to retire.

In this country, the nightingale prepares a nest at the latter end of May, of a very simple construction, made of dry leaves, generally of the oak, and lined with dry grass. It is usually placed on the ground amongst the same materials of which it is composed. This bird sometimes resides in thickets and woods. Here then let us learn another lesson.

"The bird that soars on highest wing,

Builds on the ground her lonely nest;

And she that doth most sweetly sing, .

Sings in the shade, when all things rest: 
In lark and nightingale we see

What honour hath humility.

When Mary chose " the better part,"

She meekly sat at Jesu's feet ;

And Lydia's gently opened heart

Was made for God's own temple meet:

Fairest and best acorn'd is she

Whose clothing is humility.

The saint that wears hearen's brightest crown,

In deepest adoration bends;

The weight of glory bows him down,

Then most when most his soul ascends.

Nearest the throne itself must be,

The footstool of humility.

In some parts of the country, however, nightingales are quite as common in gardens as in woods. "I have seen them," says a friend of the writer, "every year in my garden. Nor are they difficult to be observed. I have repeatedly seen them, though near-sighted, and with a strong glass have observed the powerful working of the strong muscles of the throat, as a nightingale poured forth its melody from the yet leafless upper branches of a lofty tree."

But there is a contrast the most striking to the warblings of the feathered tribes, which are heard for only a short space. A change very quickly passes even on the notes of the nightingale. The song ceases when the mother bird has hatched her brood; vigilance, 
anxiety, caution, now succeed to harmony, and the croak is the hush, the warning of danger or suspicion, to the infant charge and the mother bird. But the song of the true believer in Christ is not thus brief. From the hour he is brought to trust in Him, he may unite in the ascription which is constantly ascending; "Unto Him that loved us, and washed us from our sins in His own blood, and hath made us kings and priests unto God and his Father; to Him be glory and dominion for ever and ever:" and often does he rejoice that it is one which shall never end.

"Nearest the throne, and first in song,

Man shall his hallelujahs raise;

While wondering angels round him throng,

And swell the chorus of his praise." 


\section{THE DOMESTIC COCK.}

THE origin of this familiar fowl has long been matter of dispute. It is, however, of eastern descent, and may be traced to the jungle-fowls of India. Captain Skinner tells us, that in some parts of a forest he saw several of them, having exactly the same habits as the domestic poultry. There the cock struts at the head of his hens, and keeps a strict watch over their safety. Whenever they were disturbed by the attempts made upon them, he flew to the highest branch of some neighbouring tree, and crowed with all his might, while the hens ran into holes and corners to find a refuge. So cunning are these birds, that Captain Skinner and his party found it impossible to get within gun-shot of them with all the caution they could use.

"It has been often remarked, in illustration of Scripture," says Mr. Arundell, "that in the eastern countries the cocks crow in the night; but the regularity with which they keep what may be called the watches has not been perhaps sufficiertly noticed. I will, however, 
confine myself to one, and that is, between eleven and twelve o'clock. I have often heard the cocks of Smyrna crowing in full chorus at that time, and with scarcely the variation of a minute. The second cock-crowing is between one and two o'clock; therefore, when our Lord says, 'In this night, before the cock crow twice,' Mark xiv. 30 , the allusion was clearly to these seasons. In fact, this was altogether so novel to me at my first arrival in Smyrna, that I could calculate the hours of the night with the utmost precision, by what I termed my electrometer, as by my watch."

Innumerable are the varieties which may be traced to the primal stock, varieties arising from domestication during a long course of time, and showing what great effects may be produced on other creatures by similar circumstances. How this fowl was introduced into our own country cannot be determined; it must have been, however, at a very early date, for it was prohibited as food, among other things, by the Druids. The brutal practice of cock-fighting appears to have been brought hither by the Romans, and has been continued till a very recent period; indeed, there are some few who still practise this cruel and debasing sport.

The principal breeds now reared in Britain are, the Dorking, which is the largest; but is surpassed for the 


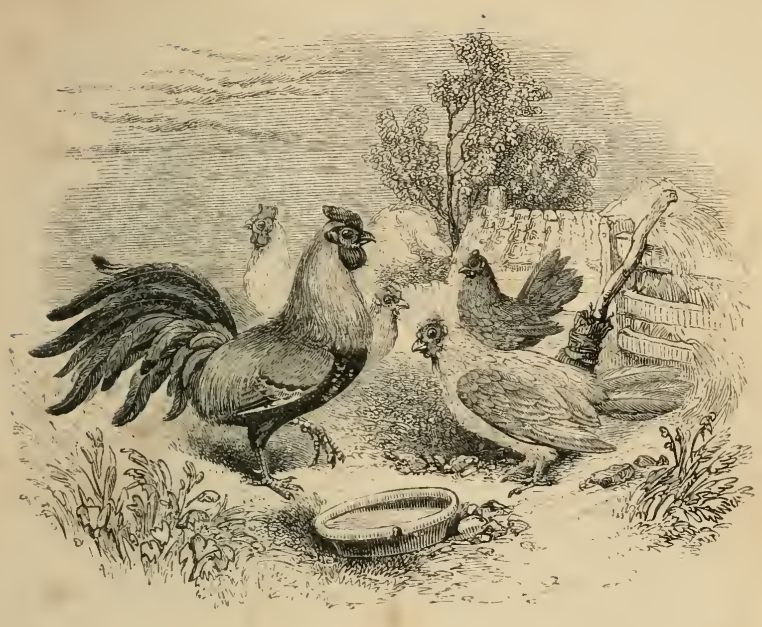

DOMESTIC FOWLS. 
table by the Poland, and the common dunghill. The Bantams are good for laying, and will hatch the eggs of pheasants, ducks, and other birds. One of the best of the laying kind is the every-day hen. A good hen, well tended, will rear one or two broods of chickens, and lay upwards of one hundred and forty eggs in the course of a year. A large proportion of those consumed in England are imported from foreign countries: 60,000,000 of eggs per annum are supplied by France, and about $4,000,000$ more are received from the Netherlands, Germany, and Denmark. Eggs may be kept sweet for three or four months if they are set on end, packed with straw, or, saw-dust, which is better, and the air carefully excluded.

The anxiety of a hen to sit, and all her after-movements, are very remarkable. The writer remembers a nest being provided for one, and the eggs being all duly arranged, when, as if perfectly aware of what had been done, she walked to it, and covered the brood with evident pleasure. Often did he look at her, and think she felt her occupation to be important, while only now and then did she leave the nest for a short time. It was pleasing also to mark the bustle that followed the hatching of the brood, the gathering of them at a well-known signal around a few crumbs or grains of 
corn, or it might indeed be only one; and the energy with which an intruder was assailed.

Tender and vigilant, indeed, is the care which the hen displays in watching over her young. She provides for them with unwearied diligence; she guards them from the attacks of their enemies with unceasing jealousy; she gives the alarm on the least appearance of danger, evincing, at the same time, a fearless intrepidity in their defence; and, with kind affection, she gathers them under her wing, and cherishes them with the genial warmth she is prepared to yield.

Such is the allusion in the words of our Lord:- " $O$ Jerusalem, Jerusalem, thou that killest the prophets, and stonest them which are sent unto thee, how often would I have gathered thy children together, even as a hen gathereth her chickens under her wings, and ye would not!" The term used by the evangelists in recording this touching lamentation, originally signified a bird of any kind; but its meaning became contracted in the progress of language, till it was appropriated to the household fowl. The propriety of this cannot be disputed. The gathering of the brood by this bird led the Arabian writers to call her emphatically, "the mother of the congregation:" and among all the feathered tribes 
the maternal qualities of the hen entitle her to a distinguished place.

The following is an interesting story from the pen of a lady. "I had once a favourite black hen, ' a great beauty,' she was called by every one, and so I thought her; her feathers jetty, and her topping so white and full! She knew my voice as well as any dog, and used to run cackling and bustling to my hand to receive the crumbs that I never failed to collect from the breakfasttable for 'Yarico' — so she was called. Yarico, when about a year old, brought forth a respectable family of chickens - little, cowering, timid things at first, but, in due time, they became fine chubby ones; and old Norna, the hen-wife, said, ' If I cuuld only keep Yarico out of the copse, it would do; but it is full of weasels, and, I am sure, of foxes too. I have driven her back twenty times, but she watches till some one goes out of the gate, and then she's off again: it's always the way with young hens, Miss; they think they know better than their keepers, and nothing cures them but losing a brood or two of chickens.' I have often thought since, that young people, as well as young hens, buy their experience equally dear.

" One morning I went with my crumbs to seek out 
my favourite in the poultry-yard; plenty of hens were there, but no Yarico. The gate was open, and, as I concluded she had sought the forbidden copse, I proceeded, accompanied by the yard-mastiff, a noble fellow, steady and sagacious as a judge. At the end of a ragged lane, flanked on one side by a quickset hedge, on the other by a wild common, what was called the copse commenced; but before I arrived near the spot, I heard a loud and tremendous cackling: I met two long-legged pullets running with both wings and feet towards home. Jock pricked up his sharp ears, and would have set off at full gallop to the copse, but I restrained him, hastening onward, however, at the top of my speed, thinking that I had as good a right to see what was the matter as Jock.

"Poor Yarico! an impertinent fox-cub had attempted to carry off one of her children, but she had managed to get behind them in the hedge, and venturing boldly forth, had placed herself in the front, and positively kept the impudent animal at bay. His desire for plunder had prevented his noticing our approach, and Jock sonn made him feel the superiority of an English mastiff over a fox-cub.

"The most interesting portion of my tale is to come. Yarico not only never ventured into the copse, but formed a strong friendship for the dog who preserved 
her family. Whenever he appeared in the yard, she would run to meet him, prating and clucking all the time, and impeding his progress by walking between his legs, to his no small annoyance. If any other dog entered the yard, she would fly at him most furiously, thinking perhaps he would injure her chickens; but she evidently considered Jock her especial protector, and treated him accordingly. It was very droll to see the peculiar look with which he regarded his feathered friend, not exactly knowing what to make of her civilities, and doubting how they should be received. When her family were educated, and able to do without her care, she was a frequent visitor at Jock's kennel, and would, if permitted, roost there at night, instead of returning with the rest of the poultry to the hen-house. Yarico certainly was a most graceful and interesting bird."

Some people set ducks' eggs under a hen; but when they are hatched, it is painful to observe the distress of the parent as they take the water, running, as she does, around its brink, and even flying into it in the effort to rescue them. It is, however, a curious fact, that habit will overcome all this natural apprehension. One hen had reared three broods of ducks in three successive years, and became, in consequence, so used to their 
practice, that she used to fly to a large stone in the middle of the pond, and watch them as they swam about, patiently and quietly. More remarkably still, she hatch. ed her own eggs the fourth year, and as her chickens did not take the water, she flew to the stone in the pond, and eagerly called them to her.

An ingenious machine for accomplishing the process of incubation, has been exhibited for some time past in Pall Mall. It forms, apparently, an oblong square. wooden box, about nine feet long, three in breadth, and three feet and a half in height, covered, excepting the doors, with cloth. It stands on a table, is unconnected with the walls against which it is placed, and is divided into eight compartments, exposed to view by the doors being glazed. Here the eggs are spread promiscuously on the floor, and appear without any covering. Inclosed in the machine is its active and regulating power.

It is capable of containing more than two thousand eggs, the heat being merely adjusted, because the temperature suited to them during the last week of the process is not sufficient for the eggs when fresh; while that which is necessary to call forth life in the latter, would destroy it in the former. With due care the average will exceed one hundred hatched daily, or about forty thousand per annum. The birds thus produced are 
full of health, strength, and activity. Soon after they are freed from the shell they are carefully fed, and tended for two or three days; they may then be seen running about the apartment; and proper means being used, they neither require nor feel the want of maternal care. There appears no difficulty in teaching the young birds adapted to the use of man, to eat and drink; they perform these operations spontaneously, from observation, or as prompted by appetite. Sickly and badly hatched birds can seldom be induced to eat, and die in consequence.

In this exhibition the whole process of incubation may be minutely observed: the eggs being broken at different points of it, and exposed to view. From one part of the machine an egg may be taken, which, if held to the ear, proves that the little tenant is labouring for its extrication, making a circular fracture of the shell with its bill, and bursting its covering by strong muscular effort; while not far off another may be observed that has just succeeded in its arduous labours. Nor should we fail to notice a pleasing instance of that wisdom and goodness which are so apparent in animate as well as inanimate nature. The chick in the egg is not liberated, as some suppose, by the aid of the parentbird; and as its tender beak would be too feeble for the 
effort, this part is provided with a scale formed of carbonate of lime - the basis of bone and of our teeth. Thus armed, the task is accomplished, and this being done-admirable, most admirable provision - the scale falls from the beak, being no longer wanted.

Another fact, equally interesting, may also be mentioned: the principal parts of the animal are formed from the albumen, the yolk being designed for the support of the little creature. The quantity appears also to be fully adapted to the case. But for this arrangement, as the eggs are hatched at different periods, the mother-bird would have to go in quest of food, as soon as the first was hatched, and leave the rest which would thus be injured: a consequence which is now completely avoided.

Other singular facts are stated by the exhibitor of the machine, to whose little treatise on the subject, and a conversation with him, the writer is indebted for many particulars. The interest in rearing a brood of chickens appears to be greatly increased by the artificial system thus adopted. Birds, very soon after they are hatched, recognise the person who feeds them; and in a few days, are said to display very pleasing traits of confidence in him as a protector and friend, following his steps, and clamorously repining at his absence. 
Even before the chick is liberated from its shell, it utters sounds in a tone and voice not to be misunderstood, asking sympathy, and showing disappointment at not being answered. Without any parent to soothe or administer to its wants, it is described as betraying surprise at its situation, and like a child just awoke out of sleep, wondering where it is, and how it came there. When, during the night, a large number of birds have freed themselves from their shells, of course in darkness, and the door of the machine, for the first time, being opened, and light bursts in, and a human head appears before them, an infant never displayed more astonishment at strange sights than is depicted in the eyes and actions of these birds: some will approach, as if to welcome that unknown something which they feel they want, while others retire in fear to the darkest corners of the dwelling.

A few hours after, spontaneously, and without teaching, some of them - and these teach the more stupid begin to eat; the effect it is thought of merely animal impulse, but soon the consequence of observation is apparent. Noting each other's actions, they learn, not only how to eat, and more especially, how to drink, but they soon discover the quality of different kinds of food. Before two days of their existence have passed, 
they can distinguish them by sight, so that if one has in its bill a delicate morsel, it is likely that some of his companions will eagerly strive to partake of the luxury.

Another curious circumstance appears in connexion with feeding. Whenever a granivorous, or grain-eating bird, in a state of nature, is caught and killed, the crop and gizzard are found, on being opened, to contain a quantity of small pebbles and other hard substances; and it is said, instinct causes the birds to swallow them. Now, of about a thousand birds reared by the machine in lofts and rooms, with bushels of fine gravel lying in heaps and scattered about, none would eat it, though several died in consequence of not doing so, by becoming crop-bound. Here then instinct failed. It appears, therefore, that as children insensibly acquire, by receiving from their parents such food as they soon learn to relish, and by observation and habit find agreeable to their stomachs and palates, so birds learn to choose and mix their peculiar food. But as, without parents to direct, few children would choose to eat the most wholesome, preferring to live on the pleasant rather than the useful, so these birds having no parents, though many endeavours were made, could not be persuaded to eat stones, though necessary for their existence.

Most of the birds thus reared, were very fine and 
beautiful, and though the greater part were cocks, there was, with few exceptions, even when arrived at nearly their full size, neither crowing nor fighting. The absence of the former was probably owing to their not hearing the thrilling clarion of older birds. As to the latter, it is often asserted that the high mettle and courage of the game cock is natural, and that if two were to meet in a desert, they would fight until one was killed. But this is an error : these birds have sufficient courage for their defence, but all beyond is the effect of training and diet. Brutal-most brutal are those persons who pervert the qualities of animals, in the hope of deriving amusement from their sufferings, or of gain from the practice of gambling, to which, unhappily, many are addicted - gambling, the parent and the offspring of vice and of crime.

Domestic fowls often display what among human beings would be called jealousy. One instance may be taken as a specimen of many. The children of the writer had a bantam-hen given them some time since, with which, of course, they were much amused. Tiny, as they called it, lived alone for some time, when another present arrived of a pair of bantams, to which the names were assigned of Robin and Beauty. Tiny, somewhat dull at first, soon became a favourite with 
Robin, and then a very malicious persecutor of his first companion. Often was she driven away for her violence, but it continucd; and as being shut up had no proper effect, she was, at length, presented to a schoolfellow. Tiny was now thrown among several fowls, and, strangely enough, she tried to pursue her former course, and to have all her own way; but the chief of the party would not suffer the aggression, and with judgment worthy a superior creature, made her keep her proper place. Meanwhile, Beauty's circumstances were changed; she had had a brood of chickens, one of which only survived, and in due time was nearly as large as her parent. A third hen was now presented to the same children; but rough, indeed, was the reception it had from Beauty and her offspring; it was, therefore, placed one evening in a hutch for defence. But, alas! this availed not; it was found next morning absolutely pecked to death through the openings in the hutch. The same feeling is strangely apparent in the male bird. It is only for a stranger to appear for an attack to commence: sometimes a furious battle ensues, and, if possible, the intruder is driven away in disgrace.

A circumstance of a different kind occurred at a gentleman's seat near Berwick. His mower cut a partridge on her nest, and immediately took the fourteen eggs it 
contained to the house. They were put under a large and very beautiful hen, her own being taken away. In two days they were hatched, and were brought up by the hen perfectly well, till they were five or six weeks old. They were kept confined during that time in an outhouse, without being seen by any of the other poultry. Unhappily, the door was left open, and the cock got in: a loud cry was heard by the housekeeper, who ran immediately out, but before she arrived, the cock finding the hen with a brood of partridges, though she had been the greatest favourite, had fallen on, and, in his rage, had killed her!

It would be well were there no resemblances to birds, in these respects, on the part of those who ought to show that they are "wiser than the fowls of the air." But, alas! how many of the young discover the selfishness which has no pleasure in the welfare of others; and even the envy, jealousy, and malice, which will lessen it by any means that can be employed. Any tendency to such dispositions is sinful; but when unrestrained, they lead to the most atrocious deeds which can be committed. How great, then, should be our concern to obey the charge, "Keep thy heart with all diligence, for out of it are the issues of life!" 


\section{THE SPARROW.}

The sparrow that "sitteth on the house-top," though often talked of, is treated with great indifference; yet there are many things respecting this bird which deserve notice. One pair will sometimes bring up fourteen, or even more, young ones in a season. While thus employed, they will consume about four thousand caterpillars weekly. They likewise feed their brood with butterflies and other winged insects, each of which, if not destroyed in this manner, would be productive of several hundred caterpillars. So bold and persevering, also, are they in providing for themselves and their young, that they will steal grain from the trough of a pig, or contend with the powerful turkey for its food; and should they be scared away, it is only for a moment, after which they return in the hope of more plunder. House-sparrows have an appetite more accommodating than that of any other of our birds. In spring, and the early part of summer, they prey on insects; but when these tribes 
become scarce, the corn and seeds of various kinds are ready, and on these they feed with equal readiness.

Here is a poet's plea in behalf of this bird:-

"Touch not the little sparrow, who doth build His home so near us. He doth follow us

From spot to spot, amidst the turbulent town, And ne'er deserts us. To all other birds The woods suffice, the rivers, the sweet fields, And nature in her aspect mute and fair ; But he doth herd with man. Blithe servant! live, Feed and grow cheerful! On my window's ledge I'll leave thee every morning some fit food, In payment of thy service. Doth he serve? Ay, serves and teaches. His familiar voice, His look of love, his sure fidelity, Bids us be gentle with so small a friend; And much we learn from acts of gentleness. Doth he not teach ?-Ay, and doth serve us too, Who clears our homes from many a toilsome thing, Insect or reptile."

Sparrows make no hasty and careless provision for the future : on the contrary, they build in places where they are likely to be perfectly safe from the plunder of larger birds and vermin. Thus they often rear their nests high in the elm, and beneath that of the rook, a bird of totally different habits, and with which they do not associate, making use of the structure only for a defence, to which no other bird resorts; and display, by 
so doing, their ingenuity, as well as their concern for the safety of their broods.

A youth, named Smellie, who in after life wrote a valuable work, "The Philosophy of Natural History," carried off a nest of young sparrows, about a mile from his place of residence. As he was marching home with his prize, he saw, with some degree of astonishment, both the parents following him at some distance, and silently observing his motions. It then struck him that they might follow him home, and feed the young in their usual way. When just entering the door, he held up the nest, and made the young ones utter their usual cry expressive of a desire for food, and putting the nest and the young in the corner of a wire cage on the outside of a window, he chose a situation in the room where he could perceive all that would happen, without being himself observed. The young birds soon cried for food; in a short time both parents, having their bills filled with small caterpillars, came to the cage, and, after chattering a little, gave one to each. This parental intercourse continued regularly for some time, till the young ones were completely fledged, and had acquired a considerable degree of strength.

Young Smellie now determined to try an experiment: he took one of the strongest of the young birds, and 
placed him on the outside of the cage, in order to observe what would take place. All doubt was soon at an end: in a few minutes both parents arrived, laden as usual with food; and no sooner did they behold one of their offspring freed from its cage, than they fluttered about, and showed with their voices as well as their wings, the greatness of their joy. At length, these tumultuous expressions gave place to calm and soothing converse : it seemed that they entreated him to follow them, while he appeared impatient to accede to their wishes, yet afraid to encounter the hazard of a first flight. Again and again he was solicited to make the attempt; when they endeavoured to show him, by flying from the cage to a neighbouring chimney-pot, how easily it might be done, and at last he committed himself to the air, and alighted in safety, being greeted again by clamorous and active joy. Next day Smellie placed another young bird on the top of the cage, and in the same way he treated the remainder of the brood; nor did one of them return.

A few years ago, a man went into a public house, and after some conversation with its inmates, stated that he had just had a present of some birds from a gentleman, in whose family he had been at work, and who was about to leave England. Taking one out of 
a paper bag, he described it as a Virginia nightingale, and as singing most melodiously, while its appearance was not a little attractive. Its head and neck were of a bright vermilion, the back betwixt the wings was blue, the lower part to the tail a bright yellow, the wings red and yellow, the belly a clear green, and in the tail many colours were blended. He said it was well worth a sovereign to any person, but after much bidding for so great a rarity, he disposed of it at last for five shillings; and as soon as he had got rid of the rest of his birds, he departed. Some time after, a neighbour came in, who soon found out that the party had been duped, and that the Virginia nightingale was only a hedge-sparrow cunningly painted. Often, however, do the fraudulent outwit themselves, and that deservedly. The man who played this trick, in all probability soon resorted to other dishonest means of obtaining money, and found the justice which he now contrived to evade.

Sometimes the increase of sparrows is very great, and the numbers of these visitants to our corn-fields are prodigious They love association, but this instinct prepares for the destruction of multitudes. As they roost in troops amidst the ivy on the walls, or ricks, and in similar situations, they are captured by the net; as they cluster on the bush, or crowd by the barn-door 
on the chaff, they are shot by dozens at a time; or they will rush one after another by numbers into the trap. Various means of destruction are so brought to diminish them during the winter seasons, that their flocks are not remarkable on the return of spring.

It was held, among the many great and awful errors of antiquity, that the Divine Being having created the universe, left it entirely to itself, and retired as if it were utterly unworthy of his superintendence. And there are many still to be found, who, in like manner, deny the gracious providence of God. But let it be remembered, that what it was becoming in the Most High to create, it must be also becoming in him to sustain. Of this we have the most distinct and impressive intimations. Low on the scale of being as the sparrow has been placed, it is, according to the declaration of our Lord himself, the object of Divine regard: "Are not two sparrows sold for a farthing? and one of them shall not fall on the ground without your Father." Though this bird does not attract our notice by the beauty of its plumage, nor awaken our regard by the amiableness of its disposition, nor command our esteem and gratitude by the benefits it dispenses, yet it is not forgotten before God. "The eyes of all wait upon thee; thou givest them their meat in due season." 
"Some, amidst India's groves of palm, And spicy forests breathing balm, Weave soft their pendant nest;

Some deep in western wilds, display Their fairy form and plumage gay,

In rainbow colours drest.

Others no varied song may pour, May boast no eagle plume to soar, No tints of light may wear; Yet, know, our heavenly Father guides The least of these, and well provides,

For each, with tenderest care.

Shall he not then thy guardian be?

Will not his aid extend to thee?

Oh ! safely may'st thou rest;

Trust in his love, and e'en should pain, Should sorrow tempt thee to complain,

Know what he wills is best."

An interesting fact in reference to the sparrow was related a short time ago in the Naturalists' Magazine : it has since been given as follows, in verse :

"I dote on every little bird That twitters in the sun-

I love them all, from having heard The simple tale of one!

In cage that 'neath the eaves was hung

When morn put forth her smiles,

A little yellow warbler sung

A song of distant isles !

One morn, when loud his melody, There came on idle wing A sparrow, and, from sympathy, Thus seem'd to say or sing :- 


\section{THE SPARROW.}

' Fair captive! why this joyous lay,

When sad should be thy heart?

Art thinking of a happier day,

Forgetful what thou art?

Perchance, while high thy music floats,

Where ne'er thy wings may flee,

Thy spirit rises with thy notes,

For they, at least, are free!

Thy song goes forth among the trees,

And up to heaven's high dome,

And haply bears thee o'er the seas

To thy own island home.

Poor bird! could'st thou come forth with me,

$I$ 'd lead thee to the grove,

Where all that's known of slavery

Is servitude to love!

How sweet to join our airy chase,

Or cower within thy nest,

Yet only bound to that one place

Because thou loved'st it best !

Alas, alas ! the wish is vain,

Thy prison-bars are strong;

But I will come to thee again,

Adieu, sweet bird of song!'

Away it flew, but day by day,

Return'd with gather'd food,

And through long months, the watchers say,

Went on this work of good.

I felt my noblest thoughts ascend,

Such heaven-taught love to trace,

And deem'd, perchance, this captive's friend,

The Howard of its race!" 


\section{THE PHEASANT.}

Pliny called these birds "Phasianæ aves," birds of the Phasis, in Asia Minor. They are brought from the banks of that river, which flows into the Euxine Sea, and are now spread, in a partially domesticated state, over the whole of temperate Europe. In our part of it the pheasant is common, and thrives tolerably well. This is not the case in many situations; it is subject to disease, and thus great mortality arises. The beauty of its plumage, and the delicacy of its flesh, render it attractive and valuable.

When Crœsus, king of Lydia, was seated on his throne, arrayed in all the royal magnificence of the East, he asked Solon, the celebrated Grecian philosopher, if he had ever beheld anything so fine? Solon, unmoved by the splendour before him, replied, that after having seen the beautiful plumage of the pheasant, he could be astonished at no other finery.

The splendid bird still meets the view, but the male alone is remarkable for its beauty: a quiet dress of 


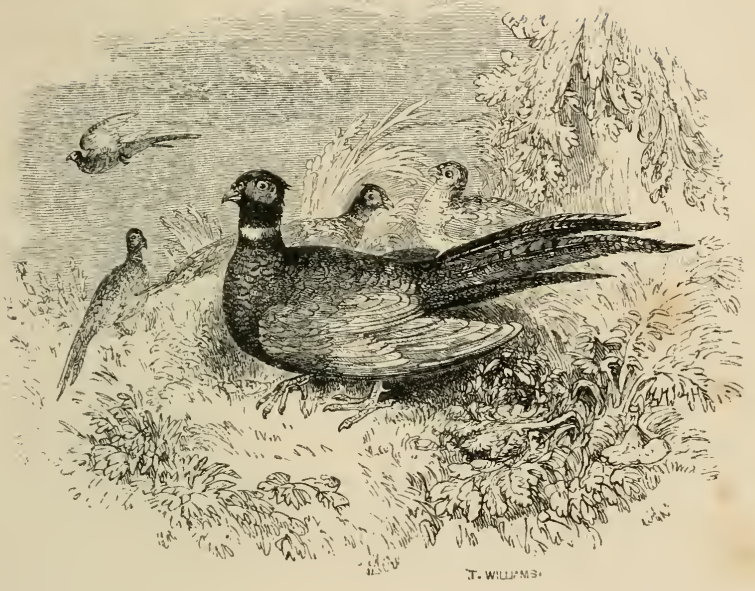

THE PHEASANT. 
brown arrays the female, often adorned, however, with spots and lines.

" Close by the borders of the fringed lake,

And on the oak's expanding bough, is seen

(What time the leaves the passing zephyrs shake,

And gently murmur through the sylvan scene)

The gaudy pheasant, rich with varying dyes,

That fade alternate, and alternate glow,

Receiving now his colours from the skies,

And now reflecting back the watery bow.

He flaps his wings, erects his spotted crest ;

His flaming eyes dart forth a piercing ray;

He swells the lovely plumage of his breast,

And glares a wonder of the orient day."

The pheasant is now found in a state of nature in almost every part of the old continent, except the northern, but it is not known in America. It bears confinement tolerably well, and produces a great many eggs in that state. The eggs are often put under a common fowl to be hatched: by this means a great many are reared every year, and afterwards let loose into the woods, which are preserved, or kept free from intruders : were it not for this, the breed would probably be soon extinct.

Luxury keeps up a demand for these birds, and the sportsman miakes them an easy prey. 
"See! from the brake the whirring pheasant springs, And mounts exulting on triumphant wings :

Short is his joy; he feels the fiery wound, Flutters in bloor, and panting beats the ground.

Ah! what avail his glossy, varying dyes,

His purple crest, and scarlet-circled eyes;

The vivid green his shining plumes unfold,

His painted wings, and breast that flames with gold !"

Sagacity is not so apparent in this bird as in many others. When roused, it will frequently perch on the first tree; and so intent is it on the dogs, that the sportsman is allowed a very near approach. At the time of their perching, too, pheasants often crow, or make a chuckling noise. While thus exposed to destruction, to say nothing of other devices, the poacher catches them with wire-nooses, twisted horse-hairs, and even with a brier set at the edge of a wood, for they always run to feed in the neighbouring fields morning and evening.

The instinct of a sitting bird is, as in all other cases, fully adapted to its circumstances. In the wild state, when relaxation is necessary, the wearied pheasant first covers her eggs, and then, instead of running from the nest, instantly takes wing. Thus she has been observed betaking herself to flight immediately from her nest in the grass, and, on her return, keeping on the wing till she dropped upon it. The reason of her so doing ex- 
hibits the care which the great Benefactor exercises over the humblest of his creatures. Were the parent to run along the ground from her nest, a scent would be produced, and a track made, by which some cunning foe might despoil her; but by this precaution, there is no clue to such a robbery. On it depends the safety of the nest and its little brood; and, doubtless, the same precaution is taught by instinct to most birds which have their nests on the ground. 


\section{THE CUCK00.}

The common cuckoo is a bird of passage, and less at home here than any other bird. It was thus addressed by Wordsworth :-

" $O$ blithe new-comer! I have heard,

I hear thee, and rejoice:

O, Cuckoo! shall I call thee bird,

Or, but a wandering voice?

While I am lying on the grass,

Thy twofold shout I hear,

That seems to fill the whole air's space-

As loud far off as near.

Though babbling only to the vale

of sunshine and of flowers,

Thou bringest unto me a tale

Of visionary hours.

Thrice welcome, darling of the Spring;

Ev'n yet thou art to me

No bird ; but an invisible thing -

A voice, a mystery !

The same whom, in my schoolboy days,

I listened to; that cry

Which made me look a thousand ways,

In tree, and bush, and sky. 
To seek thee did I often rove

Through woods and on the green;

And thou wert still a hope, a love-

Still long'd for, never seen.

And I can listen to thee yet,

Can lie upon the plain,

And listen, till I do beget

That golden time again."

The cuckoo visits this country about the middle of April, and tarries with us about four months. Its course has been marked in the following couplets:-

\author{
"In April, \\ Come he will. \\ In May, \\ He sings all day. \\ In June, \\ He alters his tune. \\ In July, \\ He prepares to fly. \\ In August, \\ Go he must."
}

The egg of the cuckoo is laid in the nests of other birds, many of which might easily be mentioned; but it appears to prefer those of the meadow pipit, the hedge warbler, and the pied wagtail. Should a second egg be found in a nest, it is thought to be laid by a second cuckoo. But, whatever may be the nest in which the 
young bird is hatched, it is generally found there entirely alone, its foster-mother attending most assiduously to its wants. Here there are several circumstances to which Dr.Jenner gave particular attention.

It was found that the small birds, in the nests of which the cuckoo commonly deposits her egg, take four or five days in laying them, and that generally after two or three of these are laid, she accomplishes her purpose. As the cuckoo is commonly hatched first, the remaining eggs, and young, if any, are turned out of the nest, and are left to perish. This, strange to say, the intruder effects, being generally strong enough for the task the day after it is hatched, thus securing to itself the whole provision brought by the old birds. The following is an extract from Dr. Jenner's paper, published in the Transactions of the Royal Society :-

"Two cuckoos and a hedge-sparrow were hatched in the same nest this morning: one hedge-sparrow's egg remained unhatched. In a few hours after, a contest began between the cuckoos for the possession of the nest, which continued undetermined till the next afternoon; when one of them, which was somewhat superior in size, turned out the other, together with the young hedge-sparrow and the egg. This contest was very remarkable. The combatants alternately appeared to 
have the advantage, as each carried the other several times to the top of the nest, and then sunk down again, oppressed by the weight of its burden; till, at length, after various efforts, the strongest prevailed, and was afterwards brought up by the hedge-sparrows.

"It is wonderful to see the extraordinary exertions of the young cuckoo, when it is two or three days old, if a bird be put into the nest with it that is too weighty for it to lift out. In this state it seems ever restless and uneasy. But this disposition for turning out its companions begins to decline from the time it is two or three till it is about twelve days old, when, as far as I have hitherto seen, it ceases. Indeed, the disposition for throwing out the egg appears to cease in a few days sooner; for I have frequently seen the young cuckoo, after it had been hatched nine or ten days, remove a nestling that had been placed in the nest with it, when it suffered an egg, put there at the same time, to remain unmolested. The singularity of its shape is well adapted to these purposes; for, different from other birds, its back from the shoulders downwards is very broad, with a considerable depression in the middle. This depression seems formed by nature for the design of giving a more secure lodgment to an egg, or a young bird, when the young cuckoo is employed in removing either 
of them from the nest. When it is about twelve days old, this cavity is quite filled up, and then the back assumes the shape of nestling birds in general."

The substances found inthe stomach of young cuckoos are various, depending upon the species of bird by which they are fed. They consist of flies, beetles, caterpillars, grasshoppers, and small snails. When fed by any of the finches, which are rather vegetable feeders, they are supplied with young wheat, small vetches, tender shoots of grass, and seeds. Adult cuckoos seem more partial to hairy caterpillars. The young are frequently found in a nest in a hedge-row, by their almost incessant querulous note, which appears to be a call for food; and they are voracious feeders. The young are sometimes, by great care, kept alive in confinement over the first winter, but seldom survive long afterwards. The best food for them is raw beef chopped small, and mixed with the yolk of an egg.

"To what cause then," says Dr. Jenner, "may we attribute the singularities of the cuckoo? May they not be owing to the following circumstances? The short residence this bird is allowed to make in the country where it is destined to propagate its species, and the call that nature has upon it, during that short residence, to produce a numerous progeny. The cuckoo's first 


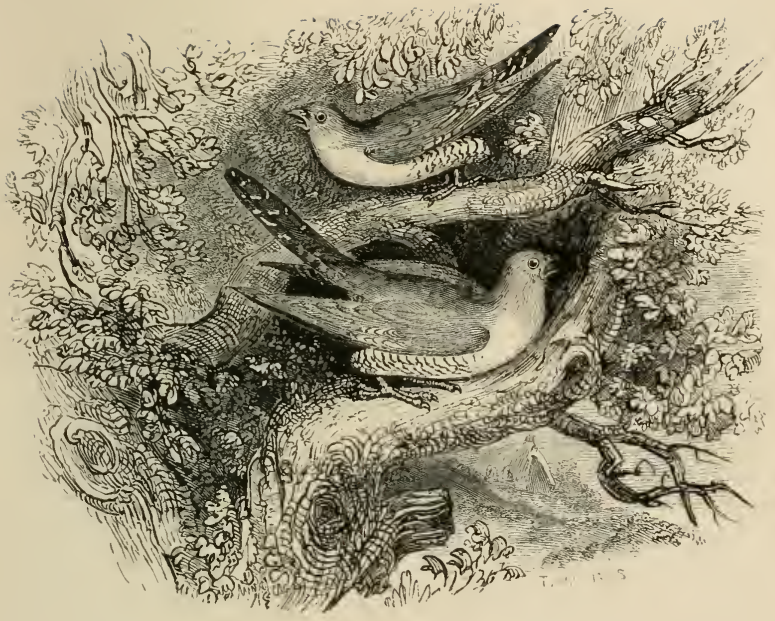

THE CUCKOO. 

appearance here is about the middle of April, commonly on the 17th. Its egg is not ready for incubation till some weeks after its arrival, seldom before the middle of May. A fortnight is taken up by the sitting bird in hatching the egg. The young bird generally continues three weeks in the nest before it flies, and the foster-parents feed it more than five weeks after this period, so that if a cuckoo should be ready with an egg much sooner than the time pointed out, not a single nestling, even one of the earliest, would be fit to provide for itself before its parent would be instinctively directed to seek a new residence, and be thus compelled to abandon its young one; for old cuckoos take their final leave of this country the first week in July."

A young cuckoo, brought to Colonel Montagu, in July, just as it could fly, was, by great care, kept alive till the middle of December. During that time it had two or three attacks of dysentery, from which it recovered by having chalk and ginger given to it. For two months after it was caught it never attempted to feed itself by picking; and even to the last moment seemed to prefer being fed by the hand of its mistress to the trouble of picking up its food, of which it was extremely choice. Nothing appeared so acceptable a substitute for insects as raw beef. It would eagerly 
derour flies; but its most delicious morsel was any species of hairy caterpillar; these insects it seized with avidity, shook them to death, and softened by passing several times through the bill, till they were quite pliant, when it would swallow whole the largest of the caterpillars of the egger or drinker moths. It was very fearful of strangers, fluttering in its cage to avoid their attentions ; but it would quietly suffer itself to be handled by a young lady, who had been its kind benefactress, appearing to like the warmth of her hand to its feet.

But now let us listen to another poet:-

"Hark! the cuckoo's sprightly note, That tells the coming of the vernal prime, And cheers the heart of youth and aged man. Say, sweet stranger, whence hast thou ta'en thy flight, From Asia's spicy groves, or Afric's clime; And who direct'st the wandering journey far? Philosophy says, instinct-Religion, God. Though simple in thy note, it speaks to man's Reflecting soul, since thou didst wing thy course From Albion's cliffs, another year is gone. A year! how short the space unnoticed by The gay and mindless throng, yet awful to The race of human kind. Another year may pass, unheeded as The one so lately number'd in the book Of Time, and thou wilt take thy flight to realms Unknown; but when thou cheer'st the future spring, will those who now admire the song, walk forth To hear the lay? This awful question brings 


\section{THE CUCKOO.}

A thousand thoughts of solemn import to Th' attentive mind. Another year! and then, O God ! the souls that greet this smiling morn, May stand for judgment at thy dreadful throne! This serious call should check man's sinful course, And raise his views to heaven." 


\section{THE BLACKBIRD.}

This bird is an early breeder : it prepares a nest composed externally of green moss, fibrous roots, and other similar materials; the inside is plastered with earth, and afterwards lined with dry grass; and the nest is generally placed in a thick bush, or against the side of a bank.

The song of the blackbird commences early in the spring, and is a shrill kind of whistle of various notes. It has much less variety and compass than the voice of the thrush, but it is far more mellow. Of this bird Grahame says :-

"When snow-drops die, and the green primrose leaves Announce the coming flower, the merle's note, Mellifluous, rich, deep-toned, fills all the vale, And charms the ravished ear. The hawthorn bush New budded, is his perch; there the grey dawn He hails; and there, with parting light, concludes His melody. There, when the buds begin, More richly full, melodious he renews."

Another poet, Montgomery, says :- "Those who live in the country, and who are apt to awake early 
on spring mornings, when all around is still, and the lark himself is yet on the ground, must often have been charmed with the solitary song of the blackbird, a brief stave of six or seven notes only, followed by an interlude of silence, during which the ear listens eagerly for a repetition. His broad and homely strain, different from that of every other minstrel of the woods, and chiming in at intervals with the universal chorus of wild throats, is likewise known from infancy to those who have been accustomed to walk abroad on spring evenings. The yellow bill and glossy black plumage of the same conspicuous bird are equally familiar to the eye of such, when he flits from hedge to tree, or across a meadow; nor less so to their ear is the chuckling call with which he bolts out of a bush before the startled passenger, who has unconsciously disturbed him on his perch.

MORNING.

"Golden Bill! Golden Bill!

Lo! the peep of day ;

All the air is cool and still,

From the elm-tree on the hill,

Chaunt away:

While the moon drops down the west,

Lies thy mate upon her nest;

And the stars before the sun

Melt, like snow-flakes, one by one.

Let thy loud and welcome lay

Pour along

Few notes, but strong." 
EVENING.

" Jet-bright Wing! Jet-bright Wing ! Flit across the sunset glade; Lying there in wait to sing, Listen, with thine head awry, Keeping time with $t$ winkling eye, While, from all the woodland shade, Birds of every plume and note Strain the throat, Till both hill and valley ring, And the warbled minstrelsy, Ebbing, flowing, like the sea, Claims brief iuterludes from thee: Then, with simple swell and fall, Breaking beautiful through all, Let thy Pan-like pipe repeat Few notes, but sweet." 


\section{THE WATER OUZEL.}

THE water ouzel frequents the sides of rocky mountain streams. As early as January or February it begins its song. In Cumberland it is known by the name of the Bessy Ducker, and has been celebrated as

"A cheerful bird that loves the stream,

And the stream's voice, and answers, in like strains, Murmuring deliciously."

Another description of it is, that its notes resemble "the sound of water gurgling among pebbles." In its farcurite haunts it breeds, and continues the whole year. The nest is very large, formed externally of moss and water-plants, and lined with dry oak leaves. It is commonly placed in some mossy bank overhanging the water ; in shape it resembles that of the wren, but is not so deep, and has a dome or covering. Its eggs are considerably less than those of the blackbird.

The ouzel seems alike indifferent to heat and cold, so long as it can be near water that is not frozen. Should a stranger find out its romantic abode, the bird, according 
to an acute observer, flits before him chirping as it goes from stone to stone, and apparently with so feeble a wing, that he imagines it unfledged, utterly incapable of rising into the air, and consequently easily taken. But as he confidently pursues, the bird flits on, flirts its tail, and now and then jerks round, as if half astonished, half inviting. But onward they fare, till they come to a bolder and tougher stratum which has impeded the stream, but at the same time has given it fall and force enough to form a pool below, which boiling where the cascade plunges or rises again, is calm enough when compared with others that have been passed. The water merely leares a clean and pebbled beach, and the lofty rocks on the other side allow no footing for a bird. Hopping, and apparently badly-winged, the ouzel halts on the beach, and forward rushes the pursuer, hat in hand to the capture, but the wet stones are treacherous, and down he falls, and dips himself. Now rising, he sees the hat which was to secure the bird, whirling round and round in the eddies. And the bird has vanished! Soon, however, it bobs to the surface, at the lower end of the pool on the other side, its feathers dry without shaking off the water, and leaping first on one stone then on another, it descends the ravine in a manner as cool and collected as that with which it rose. 
To recover the hat is a difficult task, but it may be accomplished by means of one of the long suckers of hazel growing from the tangled and gnarled stool on the bank, though if the hold be not taken cautiously, and kept carefully, there may be, as it has been said, a second dipping, and no dipper to boast of. 


\section{THE PIGEON.}

The Columbidæ, or family of the pigeon, are very extensively distributed through the earth, being found in all climates, except within the frigid zones. It is, however, in the tropical climes of Southern Asia, and the islands of the great Indian Archipelago, that they swarm in the greatest abundance and variety, because there a large supply of food, adapted to each kind, is always to be found. In these parts of the earth, most of the thick-billed pigeons, that vie with the parrots in the colour of their plumage, luxuriate amidst the thick foliage of the banyan and other trees, from which they obtain a rich and never-failing repast.

The dove is universally admitted to be a beautiful object. The splendour of its eye, the innocence of its look, the sweetness of its disposition, and the purity of its manners, have made it, in every age, the theme of admiration and praise. It is evident, from the Scriptures, that Syria abounded with doves, and the allusions 
to these birds in the sacred volume are numerous and important.

The dove was selected by Jehovah to be the messenger of peace to Noah and his family. The first time she was sent out, she soon returned, because the waters still covered the face of the earth, and she could find no rest for the sole of her foot. On her second excursion, she returned, after pursuing her flight to a much greater distance, for she did not come back till the evening, when she returned with an olive-leaf in her mouth, which Noah justly considered as a sure proof that the waters had subsided.

The practice of conveying intelligence by means of tame doves, is of long standing in the East. It has been sweetly said :-

"The dove let loose in eastern skies,

Returning fondly home,

Ne'er stoops to earth her wing, nor flies

Where idle warblers roam :

But high she shoots through air and light, Above all low delay:

Where nothing earthly bounds her flight,

Nor shadow dims her way.

So grant me, Lord, from every stain

Of sinful passions free,

Aloft, through virtue's purer air,

To steer my course to Thee! 
No sin to cloud, no lure to stay

My soul, as home she springs;

Thy sunshine on her joyful way,

Thy freedom on her wings."

In the time of the Crusades, when Acre was besieged by the professedly Christian forces, Saladin, the chief of their antagonists, continued a correspondence with the besieged for some time, by means of these winged heralds. It happened, however, that one was accidentally brought to the ground, by an arrow, before it reached the city; thus the stratagem was discovered, the communication, which would have animated the besieged by the hope of speedy succour, was stopped in its course, and the Christians compelled the immediate surrender of the city.

Doves of every species were presented on the tables of the Jews, and offered, by the law of Moses, at the altar of Jehovah. An Israelite, in the spirit of gratitude, might bring a pair of turtle-doves, or young pigeons, as a free-will offering to the Lord; but if he had neglected to reprove his brother, who had, in his presence, blasphemed the name of God, or had himself taken a rash oath, or had touched any unclean thing, he was required to bring, as a trespass-offering, two turtle-doves, or two young pigeons, the one for a sinoffering, and the other for a burnt-offering. Here a broad 
distinction is made. Sin, all sin requires an atonement, and this could only be made by one who was "holy, harmless, and undefiled." And such a one appears in the Lord Jesus Christ, of whom there were so many types under the law of Moses.

"The lamb, the dove, set forth

$H$ is perfect innocence,

Whose blood, of matchless worth,

Should be the soul's defence;

For he who can for sin atone,

Must have no failings of his own."

In Europe, the pigeons become greatly reduced in number, and are confined to its warm and temperate districts, when the corn-plants flourish, and the oak and the beech yield their perfect fruit; and even from thence they are obliged to migrate to warmer latitudes, when the ground is congealed by frost, or covered with snow.

The voice, or notes, of these birds are few; much akin to each other in all the species, and consist of guttural sounds, or frequently repeated cooings. In some birds of the family their tone is plaintive and tender, in others they are hoarse and rather unpleasant.

When a field is sown with peas, flocks of pigeons may often be observed picking up those which lie on the 
surface. Even when the seedlings are just rising out of the ground, they will move away the earth from the young stem, to get at the buried seed. No wonder that the farmer, whose interests are thus invaded, discharges his gun among these robbers, or diminishes their numbers by other means.

A few years ago, the gardener of the Vicar of Westerham, in Kent, had a young pigeon, which became so much attached to him, that it was a constant guest at table during the time of meals; and if by any circumstance the outer door was closed against the bird, it would fly upon the window-sill, and beat against the window till it was admitted; then, perching upon its master's shoulder, would seem fully satisfied.

The gardener lived at some distance from his employer, at the other end of the town, and used to go home to his dinner at a stated hour. About that time the bird might be seen upon one of the houses, patiently waiting for the man to pass. As soon as he appeared, it flew down, and, alighting upon his shoulder, was thus carried home; nor did it leave its post till the gardener had finished his meal.

It, apparently, regarded with jealousy a case of stuffed birds which the man had in his house, and was frequently found actively engaged in endeavouring to get at 
them. The bird lived for a considerable time, and gave many proofs of its sagacity; but the wife of the gardener considering that it became troublesome, one day, during the absence of her husband, and much to his dissatisfaction, had it killed.

In former times the pigeon was employed in the English factory, to convey intelligence from Scanderoon to Aleppo, of the arrival of the company's ships at that port. The name of the vessel, the time of her coming, and whatever else could be comprised in a small space, was written on a slip of paper, and secured under the pigeon's wing, so as not to impede her flight: her feet were bathed in vinegar to keep them cool, and prevent her from being tempted by the sight of water to alight, whereby delay might be occasioned, and the billet lost.

The messenger-bird had a young brood at Aleppo, and was sent in an uncovered cage to Scanderoon, from whence, as soon as set at liberty, she proceeded with all speed towards her nest. It was then usual at the season of the arrival of the ships to send pigeons to be ready at the port; but if the bird remained more than a fortnight, she would forget her young, and could not safely be trusted. The pigeons, when let fly from Scanderoon, instead of bending their course towards the high 
mountains surrounding the plain, mounted at once directly up, soaring almost perpendicularly till out of sight, as if to surmount at once all obstacles interrupting their view of the place of their destination.

In the neighbourhood of London, some years ago, was a person named Lambert, who was not only, like others, a pigeon fancier, but also a confirmed boaster, and who, therefore, on one occasion, affirmed that his birds were superior to those in any other collection. This declaration, of course, brought all the others in the neighbourhood up in arms, and one of them, named Grimaldi, said that there was no pigeon in Lambert's flight capable of accomplishing twenty miles in twenty minutes. Arrangements were now made for deciding the point at issue, and the road over which the bird was to fly was to be from the twentieth milestone on the Great North Road, to Grimaldi's house at Islington. At six o'clock in the morning, the bird selected for the trial was consigned to the care of a friend, with instructions to throw it up precisely as the clock struck twelve, at the place marked out, near St. Albans, and he, accompanied by a gentleman in behalf of the opposite party, also started off-all parties concerned first setting their watches by the dial of Clerkenwell church. It was a very dismal day, the snow lying deep on the ground, and a heavy sleet falling, so that the 
passage of the bird would be more than usually diffcult-the snow frequently blinding it. As, however, no stipulation was made for fine weather, the parties took up their appointed station, accompanied by several of their friends, and in exactly nineteen minutes after, the pigeon alighted on the roof of the house.

But the pigeons, of which this was one, were not always remarkable for accuracy, for sometimes they remained away so long on their aerial excursions, that their owner gave them up in despair. On one occasion they were absent upwards of four hours. While, however, he was concluding they were gone for ever, his attention was attracted by the apparently unaccountable behaviour of three that had been left behind, and who, with their heads elevated in the air, were all gazing with great earnestness at one point of the horizon. After straining his eyes for a long time without avail, he thought he discerned a small black speck at a great height above him. Nor was he mistaken, for, by and by, it proved to be the lost flight of pigeons returning home, probably after an excursion of several hundred miles.

Out of one hundred and ten pigeons brought from Brussels to London, in the summer of 1830, and let fly from London July 19, at a quarter before nine A. .., 
one reached Antwerp, one hundred and eighty-six miles distance, at eighteen minutes past two, or in five hours and a half, being at the rate of nearly thirty-four miles an hour. Five more reached it within eight minutes after. Thirteen others took two hours and a half more for the journey, or eight hours in the whole. 


\section{THE PARTRIDGE.}

THIs bird seems to be well-known all over the world. It is found in every country - in the torrid tracts beneath the equator, as well as in the frozen regions about the pole: not that in the same state it is prepared for circumstances so different; but $\mathrm{He}$ who formed it, and intended that it should be widely diffused, adapted it to its appointed condition. Thus, when dwelling in Greenland, the partridge, as soon as winter sets in, has a covering suited to its rigour: a warm down clothes it beneath, and its outward plumage is white, like the snow in which it seeks its food.

It has often been remarked, that the culture of waste lands renders scarce and drives off the birds which were once numerous there; but it is not so with the partridge. Wherever the husbandman prospers most, and the fields are most productive, these birds are dressed in the finest plumage, and appear in the greatest abundance. So considerable, however, is the difference between the dwellers in the richly-clothed corn-fields and those in 
the moors, that it has led to the latter being called, to mark the variety, moor-partridges.

Partridges are very prolific; the eggs being never fewer than twelve, and often as many as twenty. A hole scratched in the dry mould, commonly sheltered by a bush or tuft of grass, serves for a nest. The male takes no part in the toil of incubation; but he is attentive to his mate, and joins with her in defending the brood. Of this the following is an instance. The attention of a person was arrested by some objects on the ground, which, on approaching, he found to be a male and a female partridge, engaged in a battle with a carrion-crow. So absorbed were they in the issue of the contest, and moreover so successful, that they actually held the crow till he was seized and taken from them by the spectator. On search being made, the young birds, very lately hatched, were found concealed among the grass. It appeared that the crow, a mortal enemy to all kinds of young game, in attempting to carry off one of these, had been attacked, and that successfully, by the parent-birds.

The devices of the partridge to save its brood have often been noticed. White, of Selborne, says : - "A hen partridge came out of a ditch, and ran along shivering with her wings, and crying out as if wounded, and 
unable to get from us. While the dam acted this distress, the boy who attended me saw her brood, that were small and unable to fly, run for shelter into an old foxearth under the bank. So wonderful a power is instinct."

Another instance is more remarkable. A gentleman was hunting with a young pointer, when the dog ran on a brood of very small partridges : the old bird cried, fluttered, and ran tumbling along just before the dog's nose, till she had drawn him to a considerable distance, when she took wing and flew still farther off, but not out of the field. On this the dog returned to his master, near which place the young ones lay concealed in the grass, which the old bird no sooner perceived than she flew back again, settled once more just before the dog's nose, and, by rolling and tumbling about, drew off his attention from her young, and thus, for the second time, preserved her brood.

Captain Head describes an adventure of his with an American partridge. The snow in the woods was crisp from the night's frost, and the sun was just rising in a clear sky, when the marks of game attracted his notice, and his spaniel at the same time showed the most eager curiosity in the pursuit, quartering the ground from right to left. After walking about half an hour, the dog suddenly went in search, and on going up to him, the 
captain found him at the edge of a swamp, among a clump of white cedar-trees, to one of which he had evidently tracked some kind of bird, for he was looking stedfastly into the tree, and barking with the utmost eagerness.

The captain looked attentively, but nothing whatever could he discover. He walked round and round the tree, then observed the dog, whose eyes were evidently directly fixed upon the object itself, and still was he disappointed in perceiving nothing. In the mean time the dog, working himself up to a pitch of impatience and violence, tore with his paws the trunk of the tree, and bit the rotten sticks and bark, jumping and springing up at intervals towards the game; and five minutes had at least elapsed in this manner, when all at once the captain saw the eye of the bird. There it sat, or rather stood, just where Rover pointed, in an attitude so perfectly still and fixed, with an outstretched neck, and a body drawn out to such an unnatural length, that twenty times must he have overlooked it, mistaking it for a dead branch, which it most closely resembled.

It was about twenty feet from the ground, on a bough, and sat eight or ten feet from the body of the tree. The captain shot it, and, in the course of the morning, killed four more, which he came upon much in the same way 


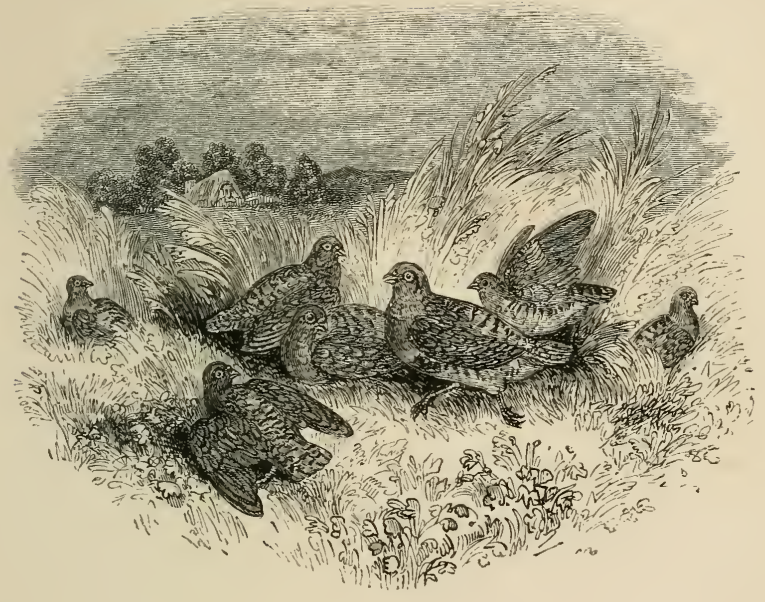

THE PARTRTDGE. 


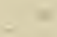


as he did upon the first. At one of these his gun flashed three times, without its attempting to move; after which he drew the charge, loaded again, and killed it. The dog, all the time, was barking and baying with the greatest perseverance. "There is, in fact, no limits," he says, " to the stupidity of these creatures; and it is by no means unusual, on finding a whole covey on a tree in autumn, to begin by shooting the bird which happens to sit lowest, and then to drop the one above him, and so on till all are killed." 


\section{THE CANARY.}

THE elegant little bird, which may so often be seen in a gay-looking cage, or sporting about in the aviaries of our country, must not be passed by because of its familiarity. Of canaries there are two distinct species, the plain and the variegated: these are more esteemed by amateurs than any of the numerous varieties which have sprung from them. They are called the gay spangles, or meally, and jonks, or jonquils.

A canary, a jonquil cock, used to nibble at his cage till he opened it, and then escaping from its prisonhouse, it would fly to the mantel-piece, where it would place itself on a china ornament, flutter as if in the act of washing, and continue to do so till water was brought. So docile was this bird as to come to the hand when called, and hide trifling articles in the corner of its cage, stopping and looking round as if to be encouraged and applauded. But a favourite amusement was, to perch on one of the branches of a tall myrtle, in a window where the cage frequently hung; and so bold did 
it become, as to dart upon the ephemeral insects that rose from a stream close by, and which appeared to yield it a delicious banquet.

In the spring of 1839 , the writer visited the exhibition in London of a "talking canary." It was a beautiful bird, which sang most melodiously, and in the course of its carol distinctly articulated the words, "pretty queen ;" "Mary;" "sweet little Dickey, dear," and some others. It was said to have had no instruction, but voluntarily to have imitated some of the sounds it heard in a family room where its cage was suspended. The writer asked if, on discovering this singular power, its exhibitors taught it any fresh words, but they replied they did not, for fear it should lose any it could utter. The presence of a large number of persons seemed rather to animate than disturb this canary, for which, it was said, five hundred guineas were offered and refused. It died in the autumn of 1839.

In the dexterity displayed by some birds, there is reason to fear that much must have been endured in preparatory discipline; and no excuse can be offered for the cruel treatment of inferior creatures. It is to be hoped it was not suffered in the following instance, the most remarkable with which the writer ever met. A native of Prussia introduced a canary-bird to a party at Cleves, 
to whom he hoped it would afford much amusement. As he held it on his finger, he thus addressed it:" Bijou, you are now in the presence of persons of great sagacity and honour; take care, therefore, that you do not disappoint the expectations they have formed. You have earned laurels; beware of their withering: in a word, conduct yourself as the bijou (the jewel) of canarybirds, as you certainly are." Meanwhile the bird appeared to listen, sloping its head to the ear of its owner, and nodding twice as soon as he had finished.

Pulling off his hat to the bird, the Prussian said:"Now, let us see if you are a canary of honour: give us a tune." The canary-bird immediately sang, but only to have the rebuke, "Pshaw! that's too harsh: 'tis the note of a raren that is hoarse!" The canary whistled forthwith most delightfully. "Faster," said the Prussian; "slower - very well! But what are this little foot and head about? No wonder you are out, Mr. Bijou, when you forget your time:- there, that's a jewel! Bravo, bravo!" he added, as the little creature did promptly all that it was required. The party expressed their surprise and admiration at its docility; and the musicians declared it was a greater master of their art than any of their band. "And do you not show your sense of this civility, sir?" said the Prussian 
with an angry air; on which the canary bowed, as we should say, most respectfully to the company.

"My poor Bijou," said the owner, "thou hast had hard work, and must be weary: a few more performances, and thou shalt repose. Show the ladies how to make a curtsey : - that's a fine bird! Now, a bow, head and foot corresponding. Now, a dance :- there, that's it-keep it up-keep it up! And now thou hast done all my biddings bravely," he said, as he caressed the little prodigy; " take a nap while I fill thy place. Again obedience was immediate : the canary first shut one eye, then the other; then nodded, and dropping so much on one side that the hands of several of the company were stretched out to save it from falling, when, just as they approached its feathers, it suddenly recovered, and dropped as much on the other.

At length, sleep seemed to fix it in a steady posture; on which the owner took it from his finger, and laid it flat on the table, where, he affirmed, it would remain in a good sound sleep while he filled up the interval. He now proceeded to drink a glass of wine, but was interrupted by the canary springing suddenly up to claim its share, putting its bill into the glass, while the owner called it a saucy fellow; and then lying down to sleep again. But this extraordinary tale has a melancholy 
close. The Prussian was attempting by his own skill to please the company, when a large black cat, which had been long on the watch, sprang unobserved from a corner on the poor bird, seized it in its mouth, and rushed out of the room notwithstanding all opposition. Pursuit was immediate, but in vain: the Prussian brought into the room the mangled body of his poor canary, with looks and words of most poignant distress. 


\section{THE SKY-LARK.}

THIS well-known bird is a great favourite. It inhabits most, if not all the countries of Europe, preferring cultivated districts, particularly arable lands when uninclosed. Grahame might well say -

$$
\begin{aligned}
& \text { "Thou, simple bird, dwellest in a home } \\
& \text { The humblest," }
\end{aligned}
$$

for it is placed on the ground, and frequently sheltered by a clod of earth, or a tuft of herbage. And with equal truth he might add -

$$
\begin{aligned}
& \text { "The daisied lea he loves, when tufts of grass, } \\
& \text { Luxuriant crown the ridge ; there, with his mate, } \\
& \text { He founds their lowly house, of withered bents, } \\
& \text { And coarsest spear-grass : next, the inner nook } \\
& \text { With finer and still finer fibres lays, } \\
& \text { Rounding it curious with his speckled breast." }
\end{aligned}
$$

Sky-larks have usually two broods in the year on the same grounds. The eggs are four or five, of a dull greenish white, mottled with brown. The first brood is usually fledged in June, and the second in August; but 
in those parts of the country where the snow lies long, it is probable there is seldom more than one brood. The song of the sky-lark is cheerful, though monotonous: but here is another description :-

"With fluttering start, in silence, from her nest The sky-lark breaks: then, steadier, upwards soars, And, with melodious trill, her prelude pours To earth, in hues of full-flushed summer drest; Now, poised on moveless wing, she seems to rest, Careless what bird, beneath the airy height, May stop her path with horizontal flight. The measured lay she breathes:- then, like a guest, Singing to other spheres, is lost in light, Till, fondly lured, she turns her faithful breast Downwards through fields of blue. The warbling strain Near and more near she swells; then, hushed again, Falls like a shadow from the sunny dome, And chaunts her three wild notes, to welcome home."

It has been observed by a naturalist, that if the lark hears the voice of its mate, it falls to the earth apparently like a stone; but that this does not take place during the period of incubation, or before the young birds have left the nest. At such times, the lark, in its descent, flies along the surface of the field, and alights at some distance from its nest. And why is this? "It is evident," he says, "that this foresight is given to it by its benerolent Creator, for the better preservation of its young; as, if it alighted at its nest, the spot might 


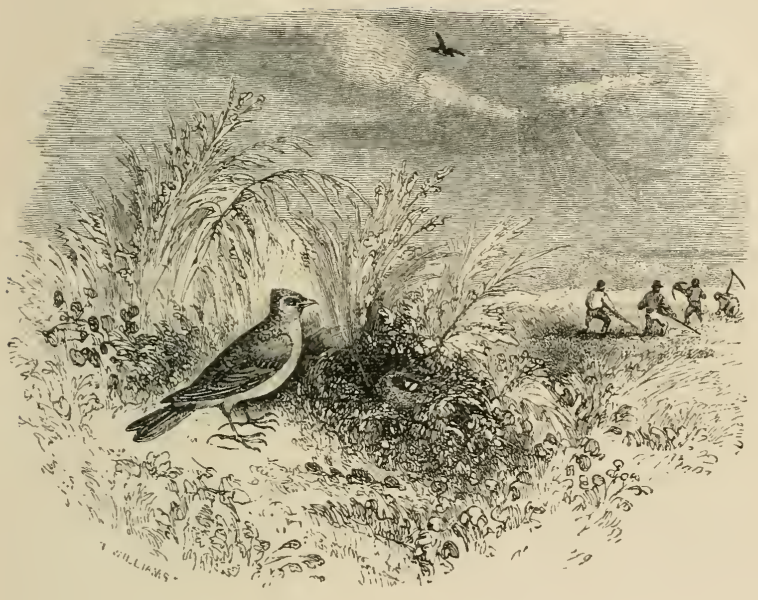

THE SKYLARK. 

easily be watched, and its young fall a prey to some marauding ploughboy."

That the lark is strongly attached to her eggs and young, has long been known. In one instance, some mowers actually shaved off the upper part of a sky-lark's nest, but she did not fly away, and they levelled the grass all about her without her taking further notice of their movements. A youth, son of the owner of the crop, observed this, and, about an hour after, went to see if she were safe, when, to his great surprise, he found she had constructed a dome of dry grass over the nest during the interval, leaving an aperture on one side for ingress and egress, thus endeavouring to secure a continuance of the shelter previously afforded by the long grass.

The same naturalist has observed, that the parents, when alarmed, remove their eggs by means of their long claws, and that very quickly, to a place of greater security; and a shepherd in Scotland recently men. tioned having witnessed the same circumstance.

The lark is a very early riser. Thus one poet says :-

"Up springs the lark,

Shrill-voiced and loud, the messenger of morn :

Ere yet the shadows fly, he, mounted, sings

Amid the dawning clouds." 
Another must, however, be considered as giving a better description, inasmuch as the writer appears to be the companion of this early bird, thus securing not only the pleasure of its song, but the many advantages never known to those who indulge in long and injurious slumbers :-

\author{
"Sweetest warbler of the skies, \\ Soon as morning's purple dyes \\ O'er the eastern mountains float, \\ 'Wakened by thy merry note, \\ Through the fields of yellow corn \\ That Mersey's winding banks adorn, \\ O'er green meads I gaily pass, \\ And lightly brush the dewy grass."
}

Birds, like other animals, sometimes display a feeling of tenderness towards the young of other birds, of which the following is an interesting instance. A young henbird was brought to a naturalist in the month of May, which was not able to feed without assistance. He caused her, he says, to be attended to, and she was hardly fledged when he received from another place a nest of three or four unfledged sky-larks. She became much attached to these new-comers, which were scarcely younger than herself: she attended them night and day, cherished them beneath her wings, and fed them with her bill.

Nothing could interrupt her offices of tenderness. If . 
she were taken from the young ones, she flew to them as soon as liberated; and if the young were torn from her, she went to them as soon as possible, not thinking of effecting her own escape. So far from her affection being diminished, it increased; she neglected both food and drink; she even required the same support as her adopted offspring, and at last expired, "consumed," says the narrator, "with maternal anxiety." Nor was this all : none of the young ones survived her; they died one after another, for want of the tender care which she had bestowed.

The number of sky-larks is very great, and in autumn their flocks are more numerous than almost any other species of our land birds. They prefer the lighter soils, where earthworms abound. In the midland counties, they are commonly in the open fields, near the chalk, and as they feed and nestle on the ground, they are captured in great numbers as an article of food. 


\section{THE WREN.}

Clare, the Northamptonshire poet, thus addresses this pretty little bird, which, like the redbreast, frequently approaches the habitation of man, and enlivens the rustic garden with its song the greater part of the year.

"Why is the cuckoo's melody preferr'd, And nightingale's rich song so fondly prais'd In poet's rhymes? Is there no other bird Of Nature's minstrelsy, that oft hath rais'd One's heart to ecstasy and mirth so well? I judge not how another's taste is caught; With mine are other birds that bear the bell, Whose songs hath crowds of happiest memories brought:

Such the wood-robin singing in the dell, And little wren, that many a time hath sought Shelter from showers in huts where I may dwell In early spring, the tenant of the plain, Tending my sheep; and still they come to tell The happy stories of the past again."

This favourite of one of our shepherd-poets enlivens our rustic gardens with its sprightly note during the greater part of the year. It very commonly builds under 
the brow of a river's bank, where the turf overhangs, from being undermined by the stream: but the wren seems equally partial to the shelter afforded by ivy on trees or walls, though it will often build under the fork of a bare overhanging bough. A nest was observed in the small upper spray of a hawthorn, though one probably appears more commonly still, sheltered under the projecting side of a haystack, or the overhanging thatch of a cottage eave.

A wren, which for many years built her nest behind an ash-tree which overhung the writer's garden, was thus addressed :-

"Little warbler, long hast thou

Perch'd beneath yon spreading bough,

Sung beneath yon ivied tree -

Thy mossy nest I yearly see,

Safe from all thy peace annoys -

Claws of cats and cruel boys.

We often hear thy chit-chat song

Call thy tiny brood along;

While in her nest, or on a spray,

The throstle charms us with her lay.

Little warbler! cheerful wren!

Spring-time comes, and thou again.

Little warbler! thou, like me,

Delight'st in home and harmless glee;

What of peace is to be found

Circles all thy dwelling round;

Here with love, beneath the shade

Thy tranquil happiness is made : 
With thy tiny, faithful mate,

Here meet'st, resigu'd, the frowns of fate.

While prouder birds fly high or far,

Or mix them in the strife of war -

Or, restless, through the world will range,

And, restless, still delight in change,

Thou mak'st thy home a place of rest,

Affection, love, and that is best!

Then welcome, welcome, faithful wren!

Thrice welcome to thy home again !"

A strong desire to wash themselves appears in some birds, while others are as much inclined to dust themselves, as, for example, the common wren. This appears to be dictated by instinct. It is scarcely possible for the little birds, in some instances, to see through the opening of their covered nests the parents dusting themselves on the ground; in other cases this could not be observed from the position of the nest; and, besides, the desire is equally powerful in all individuals. On the other hand, the nests of the wood-wren, and many birds which wash themselves eagerly on the first opportunity that occurs after they can feed themselves, could never have seen the like, their nest having been situated under the roots of a tree upon a dry bank in a wood. "This impulse," says the Hon. and Rev.W. Herbert, "is therefore inspired by the Creator; and 
it is inspired with a force that in captivity is like unto madness."

The parental feeling is strong in this little creature.

"The poor wren,

The most diminutive of birds, will fight,

Her young ones in her nest, against the owl."

Nor will any other intruders escape her power : only let a boy or a weasel come within the precincts of her abode, and she will pursue and attack most courageously, though the weight of the wren is only two drachms and three-quarters.

It appears to be possible for this commonly quiet little bird to become impudent and oppressive. A swallow had placed her nest in the corner of a piazza next a gentleman's house; another bird occupied the opposite corner; and a wren occupied a little box, made on purpose, which hung in the middle. The birds were all quite tame; but the wren had shown dislike to its dwelling, though on what account was not known, and at length it determined to drive away the swallows. Singularly enough, it succeeded in its plot; and no sooner was the exploit performed, than, with great dexterity, it removed every material to its own abode. It appeared, 
too, to enjoy its triumph; its wings were fluttered with great velocity, and great pleasure was perceptible in all its movements. Meanwhile the swallow sat meekly at a little distance, and never offered the slightest opposition ; but no sooner was the plunder carried away, than it went to work with unabated energy, and in a few days repaired the depredations. 


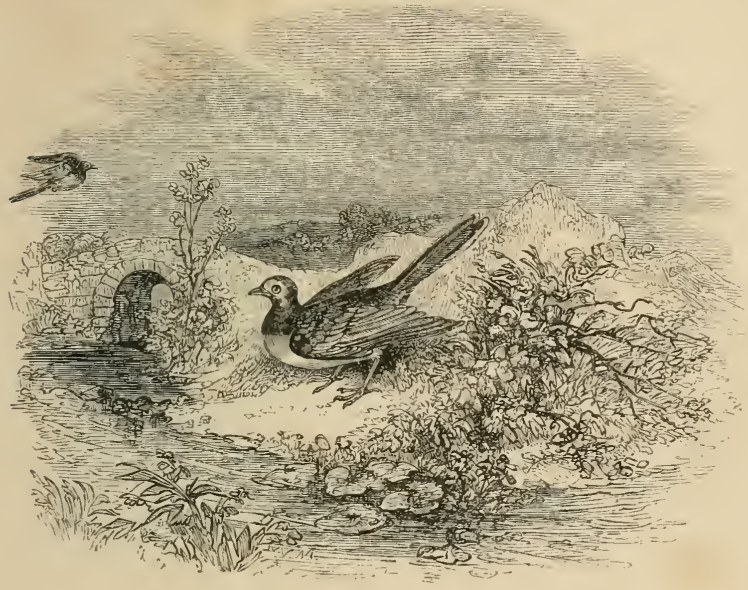

THE TVATER WAGTAIL. 


\section{THE WATER-WAGTAIL.}

THIS is a very active bird, and is constantly in motion, running after flies. It changes its abode in winter, but does not quit the kingdom, and may be found, as the weather becomes severe, in marshes subject to the flow of the tide. Early in the spring, the pied wagtails, as they are sometimes called, may be seen in flocks attending sheepfolds, and fields which have been newly ploughed. In the breeding season they appear to prefer pleasure-grounds constantly mown, where they can run about entirely unencumbered, and when the insects have not sufficient cover to evade their flight.

The nest, composed of moss, dried grass, and fibres, put together with wool, and lined with feathers or hair, is found in a heap of stones on the ground, the hole of a wall, or on the top of a pollard-tree : the hole of a bank, or the shelf of a bare rock is sometimes chosen. The eggs exactly resemble those of the cuckoo - a bird which frequently chooses the nest of the wagtail as a place for her own egg. 
This bird may become, under favourable circumstances, very familiar. One of them built a nest in a workshop at Taunton. It was not only a room occupied by braziers, whose noise was loud and incessant, but also near the wheel of a lathe, which revolved within a foot of the little dwelling. Here, strange as it may seem, the bird hatched four young ones; but the male, not accustomed to such society, appeared disinclined to follow the usual course of feeding the nestlings; for he carried the food he collected to a certain spot on the roof, where he left it, and from thence it was borne by his mate, who flew in and out of the shop without the slightest fear. She, however, was disturbed by the presence of a stranger - if in her nest, she would quit it on his appearance ; or if absent, would not return; but, the moment he was gone, she was as familiar as before. 


\section{THE LAPWING.}

THIS bird breeds early in the spring on heaths and upland situations, in fens and moist fields, and not unfrequently in old fallow land, and is common in most parts of the kingdom. The female is not so brilliant in colour as the male; some of the feathers of his crest, too, are above three inches in length, but hers are much shorter.

It is a curious fact, that the eggs of this and some other birds are commonly four, much tapering to the smaller end, and are always placed in a quadrangular manner, touching each other at the smaller ends, by which they occupy the least possible space. As soon as they are hatched, the young make use of their legs; but they are not able to fly till nearly full-grown. They are not fed by the parents, but led by them in search of food. The name of lapwing has been given this bird from the constant flapping of its wings in flight; it is also called the pe-wit, from the resemblance of its note to the sound of that word. 
To entice any animal, that may be dreaded, away from its nests or young, the lapwing has often recourse to stratagem. Some of its morements of this kind are amusing. It will strike with the bend of the wing so near to a person's head, that the stroke may be distinctly heard; and it will actually hit birds which prowl about, and even dogs. One writer tells us of his crossing a lonely moor, half heath, half quagmire, where lapwings were more than usually abundant and clamorous, and a little before him was a countryman, accompanied by one of the yelping curs of which such people are sometimes too fond. The dog seemed determined on hunting lapwings, and they as willing to give him some sport. Various, indeed, were their manœurres: they limped before him, flew low in twitches, and came close upon him, by all kinds of motions both on foot and on the wing, and the dog was fatiguing himself by hopeless leaps at the flyers, and hopeless starts after the runners. At last, one came twitching down, and struck the cur with his bill, or the bend of his wing. Audible was the blow, and, doubtless, painful too, for the dog went yelping, with his tail between his legs, to his master, and gave up, for that time at least, so profitless and disastrous a chace.

A clergyman, who kept a lapwing in his garden, 


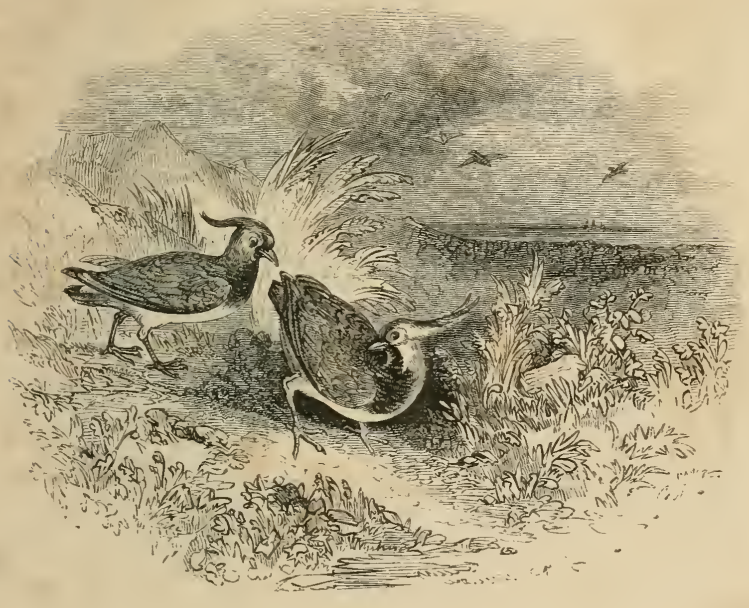

THE LAPTYING. 
observed in it some singular traits. It lived chiefly on insects ; but these failed on the approach of winter, and necessity compelled it to draw nigh the house, from which it had previously remained at a wary distance. A servant, hearing its feeble cry, as if asking for relief, opened the door of the back kitchen. It did not, however, venture far at first, but it became daily more familiar as the cold increased, till, at length, though a dog and cat were there, it actually entered the room. It afterwards became so well acquainted with these animals, as to enter the kitchen at nightfall, and to take its place at the chimney-corner, where it remained snugly by their side for the night. But as soon as spring returned, it preferred roosting in the garden, though, in the ensuing winter, it visited again the fireside. Now its former feelings were changed: naturally apprehensive of the dog and cat, it not only lost all fear of them, but treated them as its inferiors, and arrogated to itself the place it had first obtained by humble solicitation. 


\section{THE BULLFINCH.}

THis is a bird very well known. The female is much unlike the male in plumage, except in the crown of the head, which is black. It makes a nest of small dry twigs, lined with fibrous roots, in the latter end of April, or the beginning of May, most frequently in a black or white-thorn bush, either in woods or hedges; preferring the thickest places for that purpose.

This bird has no voice to charm us; it emits only a low and plaintive call to its companions in the hedge. It covets no intercourse or familiarity with man, but lives retired in some lonely thicket. As spring comes, however, it will plunder our gardens, and while some of our race make effort to obtain rarity for a banquet, these birds seldom feed on two kinds at the same time. They begin with the germs of the larger and most early gooseberry, go on to the cherry-trees, proceed afterwards to Orlean plums and green gages, and then resort to the sloe-bushes in fields and hedges.

These birds appear to have good powers of memory. 
Tame bullfinches have been observed to escape from the aviary, and live at liberty in the woods for a year; then to recollect the voice of the person that reared them, and return no more to leave her. Others, when forced to leave their first abode, have been known to die of grief. It was said of an eminent individual, that he could only recollect the kindnesses of his friends, and was forgetful of the conduct of his enemies; but of injuries these birds are said to have a clear remembrance.

One pair of bullfinches proved very interesting to an intelligent observer. They lived in a spacious and most commodious cage, and were accustomed to leave it, and partake of breakfast with their master and mistress. These birds fed from their hands, hopped upon their shoulders, and, turning their little heads round, looked with their vivacious black eyes into the faces of their benefactors :

"Strangers to liberty, 'tis true,

But that delight they never knew,

And, therefore, never missed."

The cat and they lived on perfectly amicable terms. It happened that the mistress was suddenly taken ill, and confined to her bed. The cock bird directly missed her from the breakfast-table, showed evident signs of uneasiness, looking inquiringly on all sides, and, by very 
intelligible signs, made it understood that he was troubled by her absence. In the course of the day, though he had hitherto been confined to the sitting-room, and was not supposed to have further knowledge of the house, he actually made his way up stairs, discovered her chamber, and tapped at the door with his beak.

On its being opened, he flew to the bed, fluttered about in apparent exultation, perched upon her head, and exhibited his joy in her presence by every means in his power. He remained in the chamber during the day, and, what is more extraordinary, at night, instead of returning to its mate, or even selecting a perch for his accommodation, actually nestled himself upon the pillow to rest, close beside his beloved mistress. This bird was a poor singer - in fact, no singer at all. It had been brought up by a stocking-maker of Nottingham, and constantly hearing the poor man at work, had learned the disagreeable jarring sound of the machine, which it imitated most accurately.

The gentleman who afterwards possessed the bird, disliking its unpleasant note, began to teach it to sing; but, in the first place, it was requisite to break it of what it had already learned - a task with which many a teacher of the young is perfectly acquainted: this he did by gently striking it with a knitting-needle, and 
expressing his dislike whenever it began. But the poor bird did not live to complete its lesson; and its end was a sad one. Its master and mistress going from home, left their favourite to the care of the maid. The gentleman had a misgiving in his mind as he left the door, that the bird would suffer, and actually returned after having gone some distance, to reiterate his injunctions. Of course, the servant promised attention; but on his return his presentiment was realized: the cage was empty, and, on inquiring, he found the bird had died of neglect.

The forgetfulness thus displayed was, doubtless, criminal. Inferior creatures lay claim to care on the part of those to whom they are entrusted, or whose amusement they promote. An amiable feeling often leads the young to wish for some little pet, and for a time, perhaps, it is in danger of being killed by kindness. But when the novelty has passed away, it is, in some cases, noticed less and less, until, at length, were not some more thoughtful person to interfere, the little creature would share the fate of this bullfinch.

A school for bullfinches may sound oddly, and to speak of their education may appear equally strange; yet, what is the fact? It appears that in the month of June, the young ones, which are sought for in the nests 
of wild birds, are taken when about ten days old, and brought up by a person who, by care and attention, so completely tames them, that they become perfectly docile and obedient.

At the end of about two months they first begin to whistle, from which time their education begins; and no academy can be more diligently superintended, or have pupils more effectually trained, than that of bullfinches. At first they are formed into classes of about six in each; and after having been kept a longer time than usual without food - a privation thought by children very hard to endure-and still more, confined in a dark room, the tune they are to learn is played over and over again on a little instrument called a bird-organ, the notes of which greatly resemble those of the bullfinch.

For a time, perhaps, the birds sit moping and in silence, not knowing what to make of such proceedings; but, after a while, they begin, one by one, to imitate the notes they hear. As soon as they do so, light is admitted into the room, and they are allowed a small supply of food. The sound of the organ, and the circumstance of being fed, become by degrees so associated, that the hungry bird is sure to imitate the notes as soon as they are heard. They are then given to the care of boys, whose sole business it is to carry on their education, 
each one having a bird placed under his charge, who plays away as many times as the bird can attend, during which their first teacher, or feeder, goes his regular rounds, scolding or rewarding his feathered scholars by signs and modes he has taught them to understand, until the tune becomes so familiar, that they will pipe it to the end of their lives. The writer is, however, free to confess, that he prefers "the wood-note wild" to any of the strains which are thus acquired. 


\section{THE TURKEY.}

The turkey is a native of North America: there he is the herald of the morning; and his voice must convey associations similar to those produced by the crowing of the cock in this country. "I was awakened," says Bartram, " in the morning early, by the cheering converse of the wild turkey-cocks saluting each other from the sun-brightened tops of the lofty cypress and magnolia. They begin at early dawn, and continue till sun-rise. The high forests ring with the noise of these social sentinels, the watchword being caught and repeated from one to another for hundreds of miles around, insomuch that the whole country is, for an hour or more, in an universal shout."

A person who has seen the turkey only in the poultryyards of this country, can have no idea of the splendour of a fine wild turkey-cock in his full plumage. Then it gleams with the brightest golden bronze, tinged, according to the position, with blue, violet, and green, and beautifully broken by the deep black bands which 


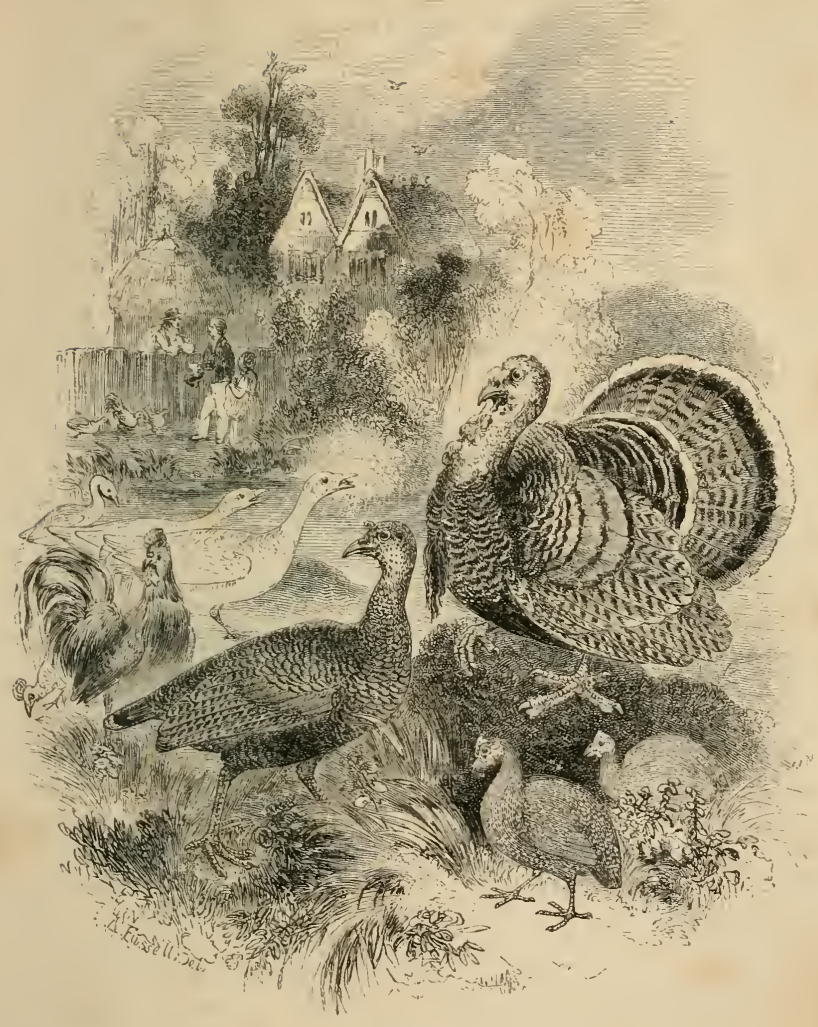

THE TURKEY. 
terminate each feather, and which also have a metallic lustre.

In the reign of George II. a large stock of wild turkeys, consisting of not less than three thousand, was regularly kept in Richmond Park. They were hunted with dogs, and made to take refuge in a tree, where they were frequently shot by the monarch. A breed of this kind is said to be in a park belonging to Lord Ducie, in Gloucestershire; and there are some in that of Sir W. W. Wynn, at Wynnstay.

In a domestic state the turkey subsists on insects and grain. The females, whenever they have opportunity, wander to a considerable distance from the poultry-yards, to construct their nests, and lay and hatch their eggs. When young, they require much attention. In Norfolk and Suffolk they are reared in great numbers. About Christmas the demand for them is great, though few birds are in more request for the table at other times. 


\section{THE CROW.}

Is young birds, the crow is to be distinguished from the rook only by the note, which is much more hoarse than that of the latter bird. In adults the difference is greater - the bill of the crow being rather more convex towards the end, and the reflected bristles at the base being always perfect. Crows keep in pairs all the year, seldom congregating except to regale on some carcase, or in winter to roost. They frequently hide their food till hunger becomes pressing. The nest is composed of sticks, plastered with earth, having soft materials laid on it, and generally placed in the forked branches of a tree.

The crow is a laborious bird; he goes to bed after the rook, and is well worthy the imitation of our young friends generally, in his keeping up a habit of early rising. Long before the rook is up, this bird is on the wing, and from the oak where he had found a dormitory, he announces, with a loud and hollow croak, the approach of man. 
There is something proverbially adhesive, as Mr. Waterton says, in a bad name. Sticking-plaster is nothing to this quality : the latter is soon rubbed off, but the former may remain for years, and even for ages. So it has been with the bird called by our ancestors the carrion crow, to point out most probably the food it was supposed to like. But had it a taste of this kind, where can it be indulged? In former times it doubtless might be, but now-a-days it would look for a meal of flesh in vain. Still it bears the same name, though it searches for food in the pastures, meadows, and corn-fields, with great assiduity.

If something may be said against the crow, because he will occasionally enter a garden to make a meal, or find a dessert in that object of delight to the young, a cherrytree, or because the nuts in autumn are the fewer for his visits, let us hear both sides of the case, and remember the destruction he deals out to millions of noxious insects.

There is, however, the grave charge to be brought of greater thefts than those already noticed. "In 1815," says Mr. Waterton; "I fully satisfied myself of his inordinate partiality for young aquatic poultry. The cook had in her custody a brood of ten ducklings, which had been hatched about a fortnight. Unobserved by 
anybody, I put the old duck and her young ones in a pond, nearly three hundred yards from a high fir-tree, in which a carrion crow had built its nest : it contained five young ones, almost fledged. I took my station on the bridge, about one hundred yards from the tree. Nine times the parent crows flew to the pond, and brought back a duckling each time to their young. I saved a tenth victim by timely interference. When a young brood is attacked by an enemy, the old duck does nothing to defend it. In lieu of putting herself betwixt it and danger, as the dunghill fowl would do, she opens her mouth, and starts obliquely through the water, beating it with her wings. During these useless movements, the invader secures his prey with impunity."

Mr. Waterton charges the crow's occasional plunder of a partridge egg on the game-keeper, who, in his rambles to find the nests of these birds, makes a track which will often be followed up by the cat, the fox, and the weasel; and still more, by driving the bird hastily from its nest, causing its eggs to be left uncovered. No wonder, then, that as the crow is in quest of food, it should pounce on the prey thus exposed, and carry off an egg on the point of its bill. But, in this case, is the bird to blame? It follows its instinct. We, how- 
ever, are in different circumstances. There are feelings of our nature, such as selfishness and cruelty, which are not to be cherished or exercised: here, and in all similar cases, we are to be concerned to subdue, not to follow, our natural character. 


\section{THE R00K.}

ThIS well-known species of crow contents itself with feeding on the insect tribe, particularly the caterpillars of the cockchafer. It sometimes takes, however, the corn of the husbandman. At all seasons it is gregarious, resorting every spring to the same trees to breed, when the nests may be observed on the upper branches crowded one over another. When the young have taken wing, they all forsake their nest-trees, resorting to them again in October to roost; but at the approach of winter, they generally choose more sheltered places at night, in some neighbouring wood, to which they fly off together.

These birds are by no means deficient in sagacity; and hence it has been said :-

"Their dangers well the wary plunderers know, And place a watch on some conspicuous bough."

Nor are they indifferent to the signal he gires: as soon as they hear it they take flight, and always in 
an opposite direction to that from which peril is anticipated.

The rook has some qualities worthy of imitation by creatures of a far higher order - the readers of this volume: it is very regular in its daily movements, and loves cordial intercourse with its kind. Other birds associate together only for a time: thus water-fowl, ringdoves, and finches, will unite in great numbers when winter spreads its coldness and desolation around; but, on the return of spring, they separate, and return in pairs. But the rook is no hermit, delighted only when afar from its species: in flocks, it builds its nest, pursues its food, and retires to rest.

The sympathy of these birds with others, when suffering, surpasses that of birds in general. Thus a large colony of rooks subsisted many years on the banks of the river Irwell, near Manchester. One serene evening, a gentleman placed himself within view of it, and marked with attention the various labours, evolutions, and pastimes of this crowded society. The idle members amused themselves with chasing each other, and in their flight they made a variety of discordant noises. In the midst of their playful exertions, one rook, by a sudden turn, unfortunately struck his beak against the wing of another, and the sufferer instantly fell into the 
river. A general cry of distress ensued: the birds hovered with every expression of anxiety over their distressed companion, and, at length, he sprang into the air, and, by one strong effort, reached the point of rock which projected into the water. Now the joy became universal; but, alas ! it was soon changed into lamentation; for the poor wounded bird, in attempting to fly towards its nest, dropped into the river, and was drowned amidst the lamentations of his whole fraternity.

Parent birds do not shrink from long-continued effort, when this is rendered necessary. In a hot summer, some years ago, many of the young brood of rooks of the season perished for want. As the mornings were without dew, few or no worms were to be obtained, and the tender birds were found dead on the trees. The cries of those that remained were very distressing, as no relief could be given them. The old birds seemed to suffer without complaint; and it was pleasing to observe the perseverance they displayed to relieve their famishing offspring, many of them remaining out in pursuit of food quite in the dusk, and returning to their roosts long after the period of retiring.

The rook is, therefore, a friend to the farmer. In ignorance or forgetfulness of this, many a rookery has been destroyed; and from the increase of destructive 
insects in consequence, the error has been lamented. In a country walk, the utility of these birds may be perceived. As the ploughman proceeds with his labour, he will be followed by rooks; but the sower will have no such companions. The power they have of discovering the grub of the cockchafer by scent, is very extraordinary. A field is described which had all the appearance of having been scorched, as if by a burning sun in dry, hot weather: the turf peeled from the ground as if it had been cut with a turfing spade; and it appeared that the roots of the grass had been eaten away by the larvæ of the cockchafer, countless numbers of which were found at various depths in the soil. Though there was no rookery within many miles of the neighbourhood, multitudes of rooks came hither, turned up the earth, and appeared to devour the grubs with great satisfaction.

Here another fact occurs which is worthy of remembrance. How often do we err in the conclusions at which we arrive? We assume that we are right, when this ought first to be determined before we flatter ourselves on the ground of our sagacity. But to select an instance:- some few years ago there were several large elm-trees behind the ecclesiastical courts of Doctors' Commons, in which a number of rooks had 
taken up their abode. On the opposite side lived a curious old civilian, who, observing from his study that the birds often dropped senseless from their perch without the cause of their so doing being apparent, set his wits to work to find what it could be. Having plenty of leisure, he weighed the matter over and over, till he was fully satisfied that he had made a great discovery, from which he expected, moreover, no little fame: he even, it is said, wrote a treatise, describing circumstantially what he had witnessed, and stated it as his settled conviction, that the rooks were subject to the falling sickness. But what was the fact? A young gentleman, who lodged in an attic near to the rooks, amused himself by silently thinning their numbers with a crossbow! 


\section{THE SWALLOW.}

OF this genus of perchers, we have three native species - the bank, the chimney, and the window swallow. The bank swallow is the smallest, is not near so plentiful, but is more local. It is frequently seen about rivers, where it makes a nest in the banks, but nost commonly in sandpits, where it can more easily form a secure place for its abode. The holes are generally horizontal, and about two or three feet deep.

This bird has been observed to cling with its sharp claws to the face of a sandbank, and use its closed bill, just as a miner would do his pickaxe, till it had loosened a considerable portion of the hard sand, and caused it to fall among the rubbish below. Some of these swallows' holes are as nearly circular as if they were marked out with a pair of compasses; while others are irregular in form, perhaps from the sand crumbling more away than in other instances. The bird always uses its own body to determine the proportions of the gallery, perching on the circumference with 
its claws, and labouring with its bill from the centre outwards. The little builder consequently assumes various positions while at work in the interior, hanging from the roof of the gallery with its back downwards as often as standing on the floor. All the galleries are more or less winding on to their termination, where a bed of loose hay, and a few of the smaller breast feathers of geese, ducks, or fowl, are spread with little art, to receive the eggs.

Some writers have thought that the bank swallow shuns the neighbourhood of man, but instances to the contrary are given by others. A colony appeared at Catrine, in Ayrshire, not only within a few yards of quarry-men constantly at work, but not a gunshot from a row of nearly a hundred houses, close by the doors of which these birds have been seen hawking for flies every hour of the day. Another colony has been observed to be established at the lime-kilns under the west side of Blackheath Hill, though surrounded by streets and rows of houses : here the nests are in the side of the precipitous bank, out of the reach of any passenger, and not easily accessible even to the determined spoiler.

The chimney swallow, so called from its breeding in our chimneys, seems to be known in most parts of the world. It is said to winter in Senegal, and probably 
in many other warm countries. In spring it returns to us, and has thus been addressed by a.modern poet :-

"Welcome, welcome, feathered stranger,

Now the sun bids Nature smile;

Safe arrived, and free from danger,

Welcome to our blooming isle!

Still twitter on my lowly roof,

And hail me at the dawn of day;

Each morn the recollected proof

Of time that ever flits away.

"Fond of sunshine, fond of shade,

Fond of skies serene and clear,

Ev'n transient storms thy joys invade

In fairest seasons of thy year.

What makes thee seek a milder clime?

What bids thee shun the wintry gale?

How know'st thou thy departing time?

Hail, wondrous bird! hail, swallow, hail!

"Sure something more to thee is given

Than myriads of the feathered race;

Some gift divine, some spark from heaven,

That guides thy flight from place to place.

Still freely come, still freely go,

And blessings crown thy vigorous wing:

May thy rude flight meet no rude foe,

Delightful messenger of spring!"

The provision made by birds for peculiar circumstances is not a little singular. The following is a case in point. A couple of swallows built their nest in a stable, and the female laid eggs in the rest, and was 
about to breed them. Some days after, the people around observed the female still sitting on the eggs, but the male flew about, and sometimes settling on a nail, betrayed his uneasiness by a very plaintive note. This led to a nearer examination, when the female in the nest was found to be dead, and her body was thrown away. Singularly enough, the male then went to sit on the eggs, and continued to do so for about two hours, when, perhaps not liking the employment, he gave it up. Still the eggs were not abandoned, for he returned the same afternoon, bringing with him a female, which sat on the nest, hatched the brood, and fed them till they were able to provide for themselves: thus showing his instinctive solicitude for the young by obtaining care for them superior to his own.

God has made us wiser than the fowls of heaven, but this is often forgotten : how many of the young, for instance, may derive a moral from the following tale. A swallow had unhappily slipped its foot into a slipknot of packthread, the other end of which was attached to a spout of a public building in France. The strength of the bird was exhausted; it hung at the end of the thread, uttering its cries, and sometimes raising itself as if endeavouring to fly away. All the swallows of the large basin between the bridges of the Tuilleries and 
the Pont Neuf, and perhaps from places more remote, to the number of several thousands, flying like a cloud, assembled together, and uttered a cry of pity and alarm.

"After some hesitation, and a tumultuous counsel," says M. Dupont de Nemours, who observed the whole, " one of them fell upon a device for delivering their companion, communicated it to the rest, and began to put it in execution. Each took his place; all those who were at hand went in turn, as in the sport of running at the ring, and, in passing, struck the thread with their bills. These efforts, directed to one point, were continued every second, and even more frequently. Half an hour was passed in this kind of labour before the thread was severed, and the captive restored to liberty. But the flock, only a little diminished, remained until night, chattering continually in a tone which no longer betrayed anxiety, and as if making mutual felicitations and recitals of their achievement."

The food of the whole genus of swallows is winged insects, in catching which they are extremely dexterous. When forgetful of the services of these little creatures, let one fact recall them to our minds. There was a time in which the North American colonists supposed that the purple grakle made sad ravages in their maize, and offered a reward for all that were killed. The 
result was, the grakles were thinned, but the insects were vastly increased, and the trouble they occasioned was proportionate. So fearfully was the grass damaged, that the colonists had to procure hay from Pennsylvania, and even from England.

At this crisis, grakles were brought from India to the Isle of Bourbon to destroy the grasshoppers; but when these birds were observed in the fields, it was supposed they were searching for the newly-sown grain; again, therefore were they proscribed, and soon not a single grakle remained. Again the insects increased; the mistaken islanders began to mourn over the loss of the birds, and about eight years after the governor obtained four of them from India, and arrangements were made for their being preserved. To protect them laws were made, and to check any disposition to eat them, a report was circulated that they were very unwholesome food. We, as certainly, owe much to the swallows.

But the window swallow is yet to be noticed. It is rather less in size than the one last mentioned. It first makes its appearance in low, warm situations, and, if the weather is fine, begins building early in May. The nest is generally placed under the eave of a house, sometimes against rocks and cliffs contiguous to the sea. How truly may we say - 
"Gentle bird! we find thee here

When Nature wears her summer vest, Thou com'st to weave thy simple nest;

And when the chilling winter lowers, Again thou seek'st the genial bowers

Of Memphis, or the shores of Nile,

Where sunny hours of verdure smile."

Marvellous, indeed, is the instinct which, after a voyage of thousands of miles have been performed, and new lands have been visited, prompts the swallow to return to the very eaves that have been left; yet such is unquestionably the fact. The following is one instance, taken from a multitude. A sparrow attempted to rob a house-marten of its nest, where lay its young and unfledged brood, and its efforts were watched from time to time by four brothers, who resolved to defend the bird that had found a shelter under their mother's roof. But, alas! the blow-guns they employed loosened the foundations of the mud-walled dwelling - down it came, and its four little inmates lay on the ground. The mother of the children, pitying the condition of the little birds, replaced them in the nest, and set it in the open window of an empty chamber. The fright of the parentbirds was soon gone, and hither they came to feed their young with their accustomed diligence, and to express in all the ways they could adopt their satisfaction and 
confidence. In due time the young birds were fledged, and from that very window they began to fly. At the season of migration, of course, they were gone; but did they lose all remembrance of the spot from whence they first tried their little wings? Oh no! The very next spring, came four martens, flying familiarly into the chamber, passing from wall to wall, and giving utterance to the joy they felt- the identical brood of the preceding year.

The reference of the inspired Psalmist to the swallow, led to the penning of the following sweet verses by the late Right Hon. Sir R. Grant. May the feelings they express be those of every reader !

"How deep the joy, Almighty Lord, Thy altars to the heart afford!

With envying eyes I see

The swallows fly to nestle there, And find within the house of prayer

A bliss denied to me !

"Compelled by day to roam for food Where scorching suns or tempests rude

Their angry influence fling, Oh, gladly in that sheltered nest She smooths, at eve, her ruffled breast, And folds her weary wing. 
"Thrice happy wand'rer!- fain would I,

Like thee, from ruder climates fly, That seat of rest to share;

Oppress'd with tumult, sick with wrongs,

How oft my fainting spirit longs

To lay its sorrows there!

"Oh! ever on that holy ground

The cov'ring cherub Peace is found,

With brooding wings serene;

And Charity's seraphic glow,

And gleams of glory that foreshow

A higher, brighter scene.

"For even that refuge but bestows

A transient though a sweet repose,

For one short hour allow'd ; -

Then, upwards we shall take our flight

To hail a spring without a blight,

A heaven without a cloud!" 


\section{THE G00SE.}

THE common goose, from which our breed is descended, must have been domesticated for many centuries. It was formerly bred in the then extensive and impenetrable swamps and fens spreading over the eastern coasts. The toil and skill of man have wrought a great change on their surface, the morass becoming a fruitful field, a garden rich in flowers and in fruit; but this part of the feathered tribes, once wandering at large, is now apparent in a highly improved and domestic state.

How much are we indebted to this bird, so proverbial for its stupidity! It gives us our quills, with some of which this, and multitudes of other books, were written. They are supposed to have been in use amongst us between four and five hundred years; and many of those employed in England came from Ireland, Hamburgh, and Hudson's Bay. An immense quantity of quills is also imported from Russia and Poland, where vast flocks of geese are fed for the sake of their quills alone: the quantity exported from St. Petersburg varies 
from six millions to twenty-seven millions. Some idea of the number of geese required to afford the supply may be formed, by considering that each wing yields about five good quills; and that, properly managed, a goose may produce twenty quills during the year.

The smaller feathers and down of these birds contribute largely to the nightly repose of multitudes. The barbarous practice has long prevailed of plucking the living bird, but it is going out of use : they are now taken from the bird as soon as it is killed, and while warm, lest the quills should lose their elasticity. Geese yield also a rich food, with which, at certain seasons, the London markets are plentifully supplied. 


\section{THE BARN OWL.}

Tris bird is a resident in our country throughout the year. It finds a dwelling in churches, barns, ruins of any sort, and also in the holes of decayed trees. If undisturbed, it seldom leaves its retreat during the day, and when cautiously approached in its hiding-place, it appears as if asleep. It begins its labours about sunset, and, as Butler says -

"While moonlight, silvering all the walls, Through every mouldering crevice falls, Tipping with white his powdery plume, As shades or shifts the changing gloom: The owl that, watching in the barn, Sees the mouse creeping in the corn, Sits still, and shuts his round blue eyes, As if he slept - until he spies The little beast within his stretch, Then starts, and seizes on the wretch !"

It has been remarked, that if this useful bird caught its food by day, instead of hunting for it by night, mankind would have full proof of its utility in thinning the country of mice, and it would, consequently, be pro- 


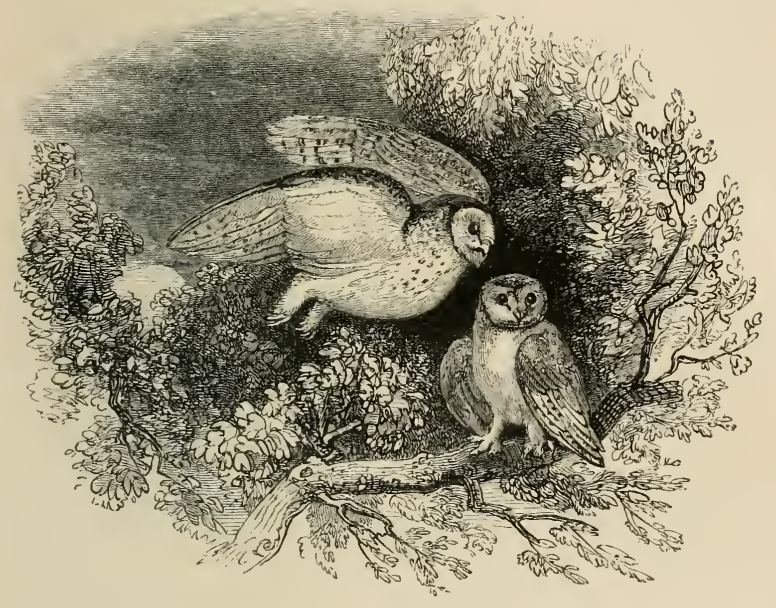

THE BARN OWL. 

tected and encouraged everywhere. But these creatures are not its only food. Standing on an eminence in an irregular country, we may observe them beating the fields over like a setting-dog, and often dropping down in the grass or corn; lanes, hedge-rows, orchards, and small enclosures near out-buildings, are also visited. Young rats, shrews, small birds, and insects, become its prey; and a gentleman in Yorkshire having noticed the scales of fishes in the nest of a pair of owls which had built near a lake, on his premises, watched their motions one moonlight night, when he saw one of them plunge into the water, and seize a perch, which it bore to its nest.

In this practice it resembles the common brown owl. The gold and silver fish had been missed, several years ago, from the flower-garden at Bulstrode, and the then Duchess of Portland, suspecting poachers had been there, ordered the gardener to employ men to watch. On this being done, the robbers were observed to alight on the side of the pond, and there waiting the approach of the fish, capture and devour them: but the delinquents were barn owls.

Another case is mentioned of later date. Some years since, several young owls were taken from the nest, and placed in a yew-tree in the Rectory-garden at Allesley, 
near Coventry, and the parents repeatedly brought them live fish, which had, doubtless, been procured from the neighbouring brook, where bull-heads and loaches abound. Since then, the Rev. Mr. Bree says, that on more than one occasion he has found the same kinds of fish, either whole or in fragments, lying under the trees, on which he had observed the young owls to perch after they had left the nest, and where the old birds were accustomed to feed them.

The large head and full feathers of the owl at once attract particular attention. Its soft and downy plumage peculiarly fits it to pass silently to its victim. The noise produced by the passage of other birds is never made by the barn owl. Its feathers, so far from resisting the air, yield to every breath, while the wings are of great extent, and, by their gentle fanning, the bird is able not only to make considerable progress, but to whirl round and drop down on its prey.

The barn owl does not make any regular nest, but lays three or four eggs, in a very slovenly manner, on some woolly or downy substance. While the young are there, the male and female sally out alternately in quest of food, returning to the nest once in about five minutes; but when there are no progeny, they tarry till they have satisfied their appetites, or are able no longer 
to see distinctly. One display of instinct is worthy remark : they bear their prey to their nest in their claws, but they usually alight on the roof, and shift it to their bill, that they may be aided by their talons in getting to their abode under the eaves.

The barn owl is thought to sleep standing, and it has been said to snore while it rests; but this appears to be a mistake : the sound that has been heard is the cry of the young for food. "I had fully satisfied myself on this score," says Mr.Waterton, " some years ago : however, in December, 1823, I was much astonished to hear the same snoring kind of noise which had been so common in the month of July. On ascending the ruin, I found a brood of young owls in the apartment."

The Mongol and Calmuc Tartars pay great honours to the white owl. Jenghis Khan, the founder of their empire, happened, when attended by a small army, to be surprised by his enemies. He was eagerly pursued, but seeking concealment in a coppice, an owl settled on a bush under which he took refuge. This place was not searched, because it was supposed that no bird would perch there under such circumstances. In consequence of this escape of their prince, his countrymen held the white owl sacred, and each one wore a plume of its feathers on his head. 
The hooting of the white owl has been denied by a careful observer, who says, "it does indeed hiss and snore in a tremendous manner." But a contrary statement has been given by Sir W. Jardine, who affirms that the white owl does hoot; that at night, when not alarmed, hooting is their common cry; and that he has shot several in the very act.

The owls have a singular mode of defence. A common barn owl, which Mr. Swainson, an eminent naturalist, endeavoured ineffectually to tame, when under a suspicion of being handled, would make a loud hissing, like what might be imagined to proceed from a serpent; it would then throw itself on its back, and begin fighting with its claws: these are such formidable weapons, that they would penetrate the flesh to the depth of an inch.

The writer well knew a little boy, to whom some one gave an owl. To him it was a great novelty, and, as such, afforded him much pleasure. But Madge, as he was called, became troublesome, and was sent, in consequence, to make an abode in the cellar. Robert regretted his departure, but against it there was no appeal. Though now long past maturity, he probably remembers one of his early adventures. It was night when he was told to fetch something from the cellar, and he proceeded thither without delay; but scarcely had he opened 
the door, when he heard a noise, so strange, so loud, that he was startled, and full of fear; and hurrying back as fast as he could go, he described his alarm, and entreated that some one else might be sent for what he was directed to bring. Loud was the laugh as he was told the noise was that of his favourite Madge; but pity operated too, for his plea prevailed; and his first was his last visit to the cellar during the short time that the owl was there.

Owls are generally harmless to man; but as they are very strongly attached to their young, it is dangerous to meddle with them. Even a suspicion of injury may fill them with rage. A carpenter passing through a field near Gloucester, was attacked by an owl that had a nest of young ones in a tree near the path. The owl flew at his head, and the man, striking at it with a tool which he had in his hand, missed his blow; on which the owl repeated her attack, and fastening on his face with her talons, injured him very seriously.

The barn owl is sometimes kept in cages and aviaries, but commonly it is the object of prejudice, and doomed to destruction. Mr. Waterton, of Walton Hall, in the county of York, to whom we have before alluded, is one of the comparatively few who regard this bird with lively interest. He tells us, that up to the year 1813 it had 
there a sad time; its supposed mourning notes alarmed the aged housekeeper; she thought it boded great evil; and as the gamekeeper stood better in her books when he had managed to shoot a barn owl, the numbers of this harmless tribe were thinned, as the result of the prevailing ignorance, superstition, and cruelty.

But, as at the period already mentioned Mr. Waterton returned from his scientific "wanderings" in the wilds of Guiana, this slaughter was stopped, an abode was made on the ruin of the old gateway, and a few weeks after it was finished, it was tenanted by a pair of owls. This settlement succeeded well, and, in consequence, others were formed. Here they only became objects of attention and interest; confident of protection, they show no fear when the stranger mounts up to their dwellingplace.

Kindness always brings with it a reward in the hearts of those who exercise it, while it is often attended by other advantages. Nor is it without them in the present instance. The barn owl amply repays its benefactor by destroying throughout the year an enormous quantity of mice. For these it will hunt not only during the night, but even when the sun shines brightly. When it has young it will bring a mouse to the nest about every twelve or fifteen minutes. It will sometimes carry off 
rats. Thus it renders a service which many can feel and acknowledge.

"The servants," says Mr. Waterton, " now no longer wish to persecute it. Often, on a fine summer's evening, with delight I see the villagers loitering under the sycamore trees longer than they would otherwise do, to have a peep at the barn owl, as it leaves the ivy-mantled tower. Fortunate for it, if, in lieu of exposing itself to danger, by mixing with the world at large, it only knew the advantage of passing its nights at home; for here

"No birds that haunt my valley free

To slaughter I condemn ;

Taught by the Power that pities me,

I learn to pity them." 


\section{THE SNIPE.}

THE common snipes are very numerous in winter, in the marshy places which afford then food and concealment; and they are increased by supplies from the north of Europe. When removing to any distance, they fly very high, and their calls can be heard when beyond the reach of ordinary sight. In the breeding season, the snipe changes its note entirely from that it makes in winter. The male will keep on wing for an hour together, mounting like a lark, making a shrill, piping noise; it then descends with great velocity, uttering a bleating sound, not unlike an old goat, which is repeated alternately round the spot possessed by the female, especially while she is sitting on her nest.

The snipe is an unsocial and solitary bird. While many of the feathered tribes, all indeed, except our birds of prey and a few others, dislike a hermit life, and are found in pairs, family parties, or flocks, the individuals of this species pass the greater part of their lives retired and alone. It is supposed they pair and raise their 
young in the deep marshy tracts or reedy districts of the fen countries, where they are defended from all common injuries, and are safe from every prying eye ; and rarely, perhaps never, are two of them found together, except at the breeding season. When the frosts of winter drive them from their covert in these watery tracts, they separate, and seek for food in a little lonely open spring, trickling from the side of a hill, tangled with grass and foliage, or some shallow rushing streamlet in a retired valley. To this spot the solitary bird becomes much attached; nor will the repeated firing of the sportsman drive him in fear from his place. 


\section{THE COMNON MALLARD.}

The mallard, or drake, as the male bird is called, is well known. In a domestic state, some of these birds appear in plumage very similar to the wild ones; but the former are generally inferior as to elegance of form. Wild ducks are found in Asia and America, as well as Europe; in summer choosing the lakes and marshes of the north, and in autumn migrating to others which are in a more temperate climate. In the marshy tracts of the British isles many remain throughout the year. Pennant mentions thirty-one thousand two hundred having been taken during one season in decoys, in the neighbourhood of Wainfleet; and it is recorded, that no fewer than two thousand six hundred and forty-six were caught in two days near Spalding. From the advance of agriculture, the common wild duck, as well as other wild fowl, is becoming gradually scarcer; few, comparatively, remaining to breed, since the more extensive fens have been drained and converted into pasture. Vast tracts of land in Lincolnshire, once fenny, now yield 


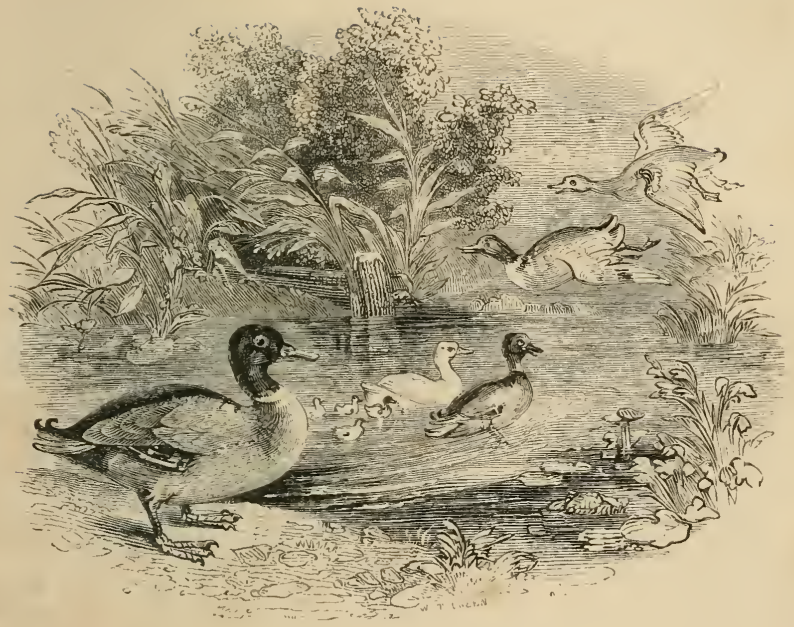

THE DUCK. 
rich grazing for cattle, and large crops of corn. Here, therefore, not a dozen broods of wild fowl are produced, where half a century back as many thousands were hatched. But there are thousands of quarters of corn, and cattle and sheep; such is the progress of national wealth and prosperity. 


\section{THE NIGHT-JAR.}

Nearly allied to the swallow, both in form and manners, is this bird, which visits England about May, and is a great destroyer of cockchafers and beetles. It hawks on the wing for insects in the dusk of the evening, and renders service to man by making them its prey. It is fond of the woods, and also the banks on the margin of rivers. Its note resembles the noise of a spinning-wheel. From its nocturnal habits it derives its name, and is often called the night-hawk, the eve-jar, and the fern-owl. It departs in the end of August, or the beginning of September.

This bird has a wide mouth, but as it cannot close its bill at the sides, it is unable to suck anything, and has therefore been called, in ignorance, the goat-sucker. In some parts of the country, too, it is thought to wean calves, by inflicting, as it strikes at them, a fatal distemper, known by the name of puckeridge. But as its structure shows it cannot injure the goat-herd, so the grazier, instead of sustaining injury, is under obligation 
to it; for this striking at the cattle is, in fact, the leap taken by the bird at the flies which in the evening torment the herd-a service of which these creatures are sensible.

White of Selborne says : - "This bird is most punctual in beginning its song exactly at the close of day so exactly, that I have known it strike up more than once or twice just at the report of the Portsmouth evening gun, which we can hear when the weather is still."

The night-jar makes no nest, but lays two eggs amongst fern, heath, or long grass, and sometimes in woods or furze, on the bare ground, but at all times near to woods, where it conceals itself during the day. It generally sits on the earth; but if disturbed, frequently perches on the branch of a tree, not across, as is usual with most birds, but generally lengthwise. 


\section{THE RATEN.}

This bird is well known among the feathered race by his harsh croaking note, and his sable plumage. It appears that black was a colour greatly esteemed among the ancients, who considered it emblematical of the inscrutable nature of Deity.

The raven delights in solitude, frequenting the ruined tower or the deserted habitation. To send a person to the ravens, was the same among the ancient Greeks as to imprecate his banishment from the comforts of civil society, his endurance of the wants and sufferings of solitary exile, his being cut off by a shameful death, his privation of the rites of burial, and his becoming a banquet to the birds of prey. The presence of the raven is the emblem of desolation, as it is when the prophet, foretelling the doom of Edom, says, "The cormorant and the bittern shall possess it; the owl also and the raven shall dwell in it;" and similar language is employed by Zephaniah in reference to Nineveh. Yes, in those splendid palaces, where the voice of joy and glad- 
ness was heard, silence, in consequence of the wickedness of their inhabitants, was to prevail, interrupted only by the scream of the cormorant, and the croaking of the raven.

Solomon says, "The eye that mocketh at his father, and despiseth to obey his mother, the ravens of the valley shall pick it out, and the young eagles shall eat it." Some light will be cast on this passage, by remem. bering that it was a common punishment in the East, and one which the Orientals dreaded above all others, to expose the bodies of evil-doers that had suffered by the outraged laws of their country, to be devoured by the beasts of the field and the fowls of heaven. An old man in Aristophanes deprecates being given as a banquet to the ravens; and Horace represents such a punishment as the most degraded of all. It has, therefore, been conjectured, that Solomon alluded to the valley of Tophet, in the neighbourhood of Jerusalem, which the prophet Jeremiah calls the valley of the dead bodies, because those of criminals were cast into it, and there they remained without burial, till they were devoured by flocks of ravens, which collected for that purpose from the surrounding country. Should this conclusion be correct, the meaning of Solomon will be-He who disobeys his parents, exposes himself to an infamous 
punishment: he shall be cast into the valley of the dead, and shall be a prey to the voracious raven. Death was the punishment of this offence under the Mosaic law, and it always must be chargeable with great guilt, and attended by the Divine displeasure.

And yet, however repulsive the raven may sometimes appear, it is described as an object of care to the Maker and Preserver of all things. When the voice of the Most High addressed Job out of the whirlwind, it inquired, "Who provideth for the raven his food? when his young ones cry unto God, they wander for lack of meat." For while God " giveth to the beast his food," he ministereth also "to the young ravens which cry." "Consider the ravens," said our Lord : "for they neither sow nor reap ; which neither have storehouse nor barn; and God feedeth them." For these creatures are the work of infinite wisdom and power; they have their proper sphere of action, and they usefully employ their qualities and instinct both for themselves and the other parts of the lower creation. With what force and point then does the argument of the gracious Redeemer come to us:-If your heavenly Father listen to the cry of the young raven, will he not much more make you his care? He is too great for any thing to be little in his estimation. 
"The insect that with puny wing

Just flits along one summer's ray,

The floweret that the breath of spring

Wakes into life for half a day,

The smallest mote, the slenderest hair,

All feel our common Father's care.

" E'en from the glories of his throne

$\mathrm{He}$ bends to view our wandering ball;

Sees all, as if that all were one,

Loves one, as if that one were all,

Rolls the swift planets in their spheres,

And counts the sinner's lonely tears."

The raven is a bird of much sagacity, though sometimes chargeable with no little mischief. Some years ago there was one at an inn on the road between Brixton and Ashbourn which had been taught to call the poultry when they were fed, and that with much success. It would not be easy to imagine how far the ability thus attained was, on one occasion, carried. At this place the passengers by one of the coaches used to stop for dinner, and at the time referred to, the usual preparation was made, the cloth being laid, and the knives and forks, spoons, mats, and bread, all being placed in due order. But when the coach was about arriving, and dinner was being carried on, what was the surprise of the attendants on discovering that all of them were gone! Not one was left. The mystery was, however, soon unravelled. The room-door of the dining-room 
had been shut, but the window was left open; and through it - roused, shall it be said, by strong ambition for a similar display? - the raven had entered; and now the result appeared, for on a heap of rubbish in the yard, the spoons, knives, forks, and mats were carefully set out, and the raven was doing the honours of the table, and regaling a numerous company of poultry with a dinner of bread.

Another fact may be mentioned of a different kind. A gentleman was entering the yard of the Red Lion inn, at Hungerford, when his chaise ran over and bruised the leg of his Newfoundland dog. While he and others were examining the injury, a raven, called Rafe, which had lived there some time, was evidently a concerned spectator of what was transpiring. No sooner was the dog tied up under the manger with the horse, than Rafe brought him bones, and attended on him with particular and repeated marks of kindness. When this was mentioned to the ostler, he said that the bird had been brought up with a dog; that a mutual affection was manifested by them, and that their reciprocal acts of kindness had been witnessed by the whole neighbourhood. Rafe's poor friend after a time broke his leg, and all the while he was confined the bird waited on him, carried him his provision, and scarcely ever left 
him alone. One night the stable-door was shut by accident, and Rafe was thus deprived of his friend's company; but in the morning the ostler found the door so pecked away, that had it not been opened, the raven would have made an entrance for himself in another hour. Other acts of kindness shown by this bird to dogs in general were mentioned; but it was stated that he was particularly attentive to maimed or wounded ones. 


\section{THE C $00 \mathrm{~T}$.}

THE coot is, in this country, a very common bird. It breeds in many of our lakes, rivers, and large ponds, forming a nest of flags among the reeds and other aquatic plants, close to the surface of the water.

Many of these birds continue in their breeding-places, even in small pieces of water, and though frequently roused, cannot be made to fly farther than from one side to the other. In the isle of Sheppey they are said to breed in great abundance; and the inhabitants will not suffer the eggs to be taken, as the birds are a chief article of food. They place their nests among the flags on the surface of the water ; and by heaping a quantity of materials together, raise the fabric above it so as to keep the eggs dry. A sudden gale of wind has been known to move them from their slender moorings, when in this buoyant state; and it is said, that the nests have been seen floating on the water, with the birds upon them. 


\section{THE ROBIN.}

IT is only to mention this bird to call up at once its well-known figure. Its most striking characteristic does not, however, at first appear ; the nestling feathers of young birds are spotted, and the red hue does not adorn the breast for two or three months after they leave their early home.

No one of the feathered tribe is more generally a favourite than the robin. How truly is it said :-

"The herdsman on the upland hill,

The ploughman in the hamlet near, Are prone thy little paunch to fill, And pleased thy little psalm to hear.

"The woodman seated on a log,

His meal divides atween the three;

And now himself, and now his dog,

And now he casts a crumb to thee.

"For thee a feast the schoolboy strews

At noontide, when the form 's forsook;

A worm to thee the delver throws, And angler when he baits the hook 
"In tents where tawny gipsies dwell,

In woods where hunters chase the hind, And at the hermit's lonely cell,

Dost thou some crumbs of comfort find.

"Nor are thy little wants forgot

In beggar's hnt, or Crispin's stall;

The miser only feeds thee not,

Who suffers ne'er a crumb to fall.

"The youth who strays, with dark design,

To make each well-stored nest a prey,

If dusky hues denote them thine,

Will draw his pilfering hand away.

"The finch a spangled robe may wear,

The nightingale delightful sing,

The lark ascend most high in air,

The swallow fly most swift on wing:

"The peacock's plumes in pride may swell,

The parrot prate eternally;

But yet no bird man loves so well

As thou with thy simplicity."

The robin is said to be of a migrative species, but only because it appears more frequently about our dwellings in winter. Then insects are not found in the woods and fields, and so it seeks the protection of man, coming to the windows before which crumbs are cast, entering, perhaps, the room, and making itself even so much at home as to gather up those which have fallen from the table. As that season retires, it commences its labours, being a very early builder, and usually 


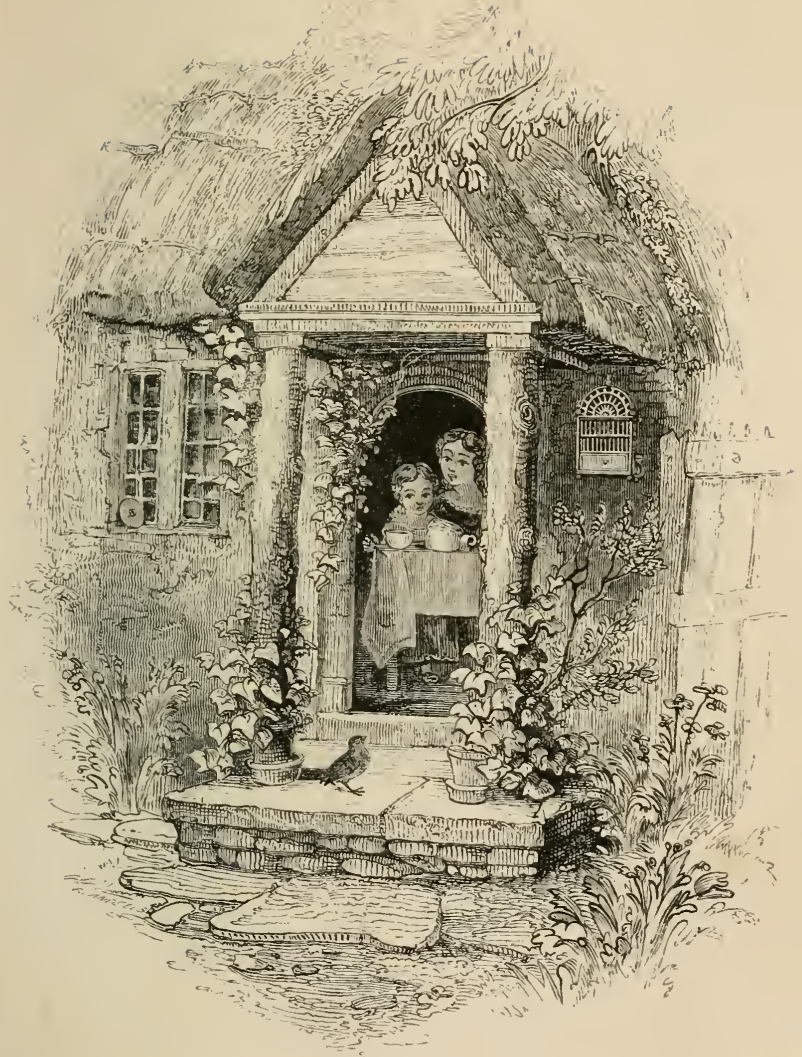

THE ROEIN. 

chooses for its nest a shallow cavity among grass or moss in a bank, or at the foot of a tree. Not unfrequently too are the words of the poet verified:-

" High is his perch, but humble is his home, And well concealed; sometimes within the sound Of heartsome mill-clack, where the spacious door, White with dust, tells him plenty reigns around :

Close at the root of brier-bush that o'erhangs

The narrow stream, with shealings bedded white, He fixes his abode, and lives at will. Oft near some single cottage he prefers To rear his little home; there, pert and spruce, He shares the refuse of the good wife's churn; Nor seldom does he neighibour the low roof Where tiny elves are taught."

A redbreast built her nest in a little hollow on the side of a heap of manure, the materials of which were brought partly from the stable, and partly from the seashore, the heap being placed in an enclosure on the outside of a garden, and under a sort of pent-house formed by a lock of the sea-weed. Here, too, she hatched her young, undisturbed by the persons continually passing by, though her nest was very near to the garden door, and apparently unmolested also by the manure-heap being dug away within a couple of feet of her abode, which she entered and left whoever happened to look on.

Another redbreast found an abode in a house standing 
in a garden. This dwelling was almost covered with ivy : round some of the windows was a light trellis, with which roses and other flowering plants were interwoven, and on the sill of one of them, and in a snug recess within the trellis, the nest was formed. It was the window of a parlour, from which she was often observed by the different members of the family, though she would frequently have escaped notice but for the bright sparkling of her eye. But as the window was not opened, and care was taken not to disturb her, she in due time hatched her brood, and carried off her young in safety.

A pair of robins chose for their dwelling a small cottage, which served as a depository for potatoes, harness, and various other articles, and was often visited by its owners. It closely adjoined, too, a large blacksmith's shop, where a huge hammer, worked not by hand, but by water, kept up a constant noise. These circumstances might be supposed to alarm the settlers, but they were undisturbed : they entered through a windowframe, the lattice of which had been removed, and actually built their first nest, early in the spring, in a child's covered cart, which, with its horse attached to it, was hanging to a peg over the fire-place, and just afforded space for the purpose. So curious a circumstance at- 
tracted attention, and many came to look at the nest, where the birds, without displaying any alarm, reared their first brood.

As soon as their offspring were full-fledged, they set about providing for another family, and built their second nest on a shelf, close to an old mouse-trap, on the opposite side of the room. Here again they had many visitors, but in due time dismissed their progeny. A third nest was soon afterwards built under the same roof. Another shelf was now chosen in a different corner of the same room, and there were soon seen in their mossy bed, placed on a bundle of papers, four halffledged nestlings, the hen-bird entering the room while the party were there.

The song of the robin attracts regard not only for its sweetness and peculiarity, but also for the indication it affords of changes in the atmosphere. When spring comes he warbles, for a short time, in so singular a strain, as even to startle and puzzle those who often listen to the notes of birds. Though the weather in summer may be unsettled and rainy, he is sometimes observed on the roof of a house, or on some topmost twig in the evening, pouring forth his mellow or liquid notes, and singing cheerfully and heartily. Now he will be found a kind of barometer, for he foretells succeeding 
fine days. The reverse is the case, though the atmosphere is dry and warm, if, in a melancholy state, he chirps and broods in a bush, or hides in a hedge. In autumn his pipings are grave but sweet; and in winter a few chirps are all that are to be expected.

Many a reader will sympathize with Dr. Jenner as he said :-

"Come, sweetest of the feather'd throng!

And soothe me with thy plaintive song:

Come to my cot, devoid of fear,

No danger shall await thee here;

No prowling cat, with whisker'd face,

Approaches this sequester'd place ;

No schoolboy, with his willow bow,

Shall aim at thee a murderous blow;

No wily limed twig e'er molest

Thy olive wing or crimson breast.

Thy cup, sweet bird ! I 'll daily fill

At yonder cressy, bubbling rill ;

Thy board shall plenteously be spread

With crumblets of the nicest bread;

And when rude Winter comes, and shows

His icicles and shivering snows,

Hop o'er my cheering hearth, and be

One of my peaceful family;

Then soothe me with thy plaintive song,

Thou sweetest of the feather'd throng." 


\section{THE STARLING.}

THIS is a plentiful species. It is found in almost every part of the old continent. Many stay with us the whole year; but the rast flocks seen in severe winters probably migrate hither in search of food, and return northward in the spring. Starlings chiefly feed on insects, but if these fail, they will eat grain. In winter they will resort to our pigeon-houses for the sake of warmth; and here great numbers are frequently taken. They make their nests of dry grass, in old buildings, or in the holes of trees. The natural notes of this bird are a chattering noise and a shrill whistle; but in confinement it becomes very docile, and puts forth its imitative powers.

Mr. Syme says, he went one morning with a friend to see a collection of birds belonging to a gentleman in Antigua-street, Edinburgh; and among these were some very fine starlings, one of which cost five guineas. Breakfast was ready before they entered the room. When the bird was produced, it flew to his master's 
hand, and distinctly pronounced, "Good morning, sir. Breakfast! breakfast!" It afterwards hopped to the table, examined every cup, and while thus employed, occasionally repeated, "Breakfast! breakfast! - bread and butter for Jack ! - tea ! tea! — bread for Jack !Pretty Jack! - pretty Jack !" 


\section{THE GOLDFINCH.}

The "sheriff's man," or "seven-coloured linnet," as this bird is sometimes called, is one of the most brilliant of the feathered tribes. It is docile in confinement, has a pleasing song, is fond of society, and when a little mirror is placed in the cage, may be seen taking its food, grain by grain, to eat it at the glass, supposing, doubtless, it is feeding in company. But to see it in its prime, it must be beheld as the poet has described it:-

"Goldfinch, pride of woodland glade,

In thy jet and gold array'd, Gentle bird, that lov'st to feed On the thistle's downy seed;

Freely frolic, lightly sing, In the sunbeam spread thy wing: Spread thy plumage, trim and gay, Glittering in the noontide ray; As, upon the thorn-tree's stem Perch'd thou sipp'st the dewy gem.

Fickle bird, for ever roving, Endless changes ever loving; Now in orchards gaily sporting, Now to flowery fields resorting; 
Chasing now the thistle's down,

By the gentle zephyr blown;

Lightly on thou wing'st thy way, Always happy, always gay."

The nest of the goldfinch is correctly described by Grahame, when he says :-

"The goldfinch weaves, with yellow down inlaid,

And cannach tufts, his wonderful abode :

Sometimes suspended on the limber-ends

Of plane-tree spray, among the broad-leaved shoots,

The tiny hammock swings to every gale:

Sometimes in closest thickets 'tis conceal'd ;

Sometimes in hedge luxuriant, where the brier,

The bramble, and the plum-tree branch,

Warp through the thorn, surmounted by the flowers

Of climbing vetch and honeysuckle wild."

One gentleman, observing a pair of goldfinches beginning to build, saw that they had formed the groundwork with moss, grass, etc. as usual; but on his scattering small parcels of wool in different parts of the garden, they, to a great extent, left off the use of their own stuff, and employed the wool. He afterwards gave them cotton, on which they rejected the former, and proceeded with the latter: the third day he supplied them with fine down, on which they finished their work with this, in preference to both. The nest, when completed, was something larger than is usually made by this bird, but it retained the pretty roundness of figure 


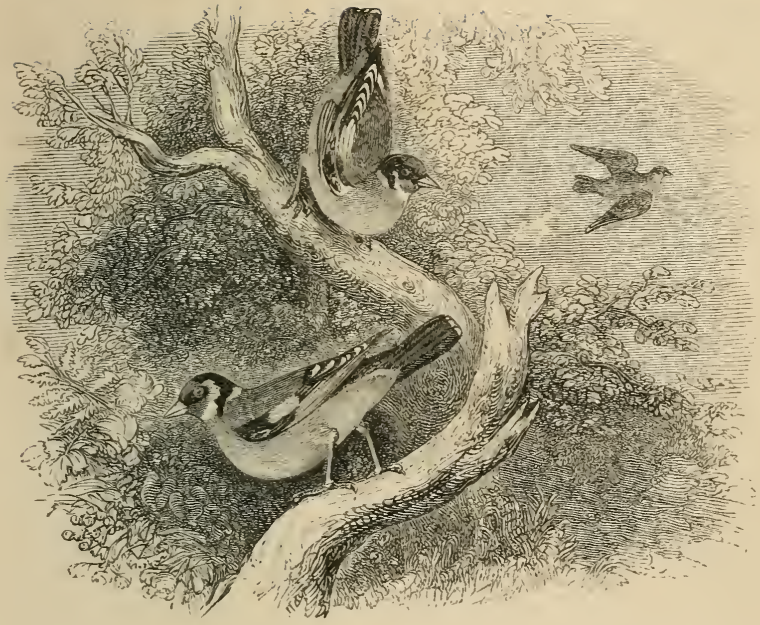

THE GOLDFIXCH. 
and neatness which it usually displays. This abode was completed in the space of three days, and remained unoccupied for the space of four days : the first egg was not laid till the seventh day from beginning the work.

The goldfinch sometimes builds in hedges; but most commonly in trees, especially those which are evergreen. The native song is not inelegant, but it is seldom pure in confinement. This bird is fond of plaintain, chickweed, and hempseed, and the seeds of the thistle and teazel.

In a very comfortable cottage, not a hundred miles from Derby, lived an old man and his daughter, and from year to year they were robbed of the cherries that grew on a very fine tree, by bullfinches, sparrows, chaffinches, and other voracious birds, which came hither for many a delicious repast. Various means were tried to deter these invaders, but all of them failed; and, at length, an old woman was made of straw, and duly attired in gown, apron, bonnet, and shawl—or it may have been a red cloak, but this is not material to the storyand she was seated snugly in the middle of the cherrytree, to keep guard, early in the year.

The buds, the leaves, the blossoms, and the fruit, all came, as usual, in their turn, but it was only for the cherries to be devoured as formerly by the birds, who 
chirped, and hopped, and sang about the branches, as though the tree had been left without any such defence. At this continued loss, the father and daughter were surprised, as well as disappointed, and they called in the gardener to determine what it was best to do. $\mathrm{He}$ heard the case, and without an unnecessary word, he borrowed a ladder, set it against the tree, and climbed to the top, when he found that the old woman had betrayed her trust. "Not only," says Montgomery, to whom we owe a much longer, but very interesting account, " not only did she let foraging parties of the enemy plunder the fair boughs, but she had actually taken a pair of them into her bosom, just where the shawl or cloak was pinned across." There they were, goldfinches, red, yellow, and black, bringing up a family of plump, half-fledged chirpers, with bills all agape, as soon as John's finger was pointed towards them. " And so," it may be said, "to execute his master"s wishes, he tore down the nest, and left the young, like many a thoughtless schoolboy, on the earth." But no, that is altogether a mistake. The result was totally different. "Do not hurt the little folks, John," said the old man. "I should like to pull a crow with the big ones!" cried the daughter: " but never mind, come down, John ; I forgive them."

The reader may, perhaps, know a range of dark brick 
walls in Piccadilly, which shut out the view of Burlington house, built that its first inhabitant might be quite out of town. Just before this range, many years ago, a man used daily to take his stand for the sale of birds. His object of attraction, which frequently had a crowd round it, was a goldfinch, who, at a given signal, feigned death : the eyes closed, the feathers were ruffled, and when taken by the leg it looked perfectly inanimate. Yet on a signal equally well known, it started up all life and activity.

The biographer of the late Rev. Henry Gauntlett says:- "The principal amusement of his childhood (and it was a predilection my father retained to the close of life) was the natural history of birds. With their haunts, instincts, and habits, he was well acquainted; to which was added an acute perception of the characteristic melodies of their various tribes. His friends have often heard him relate an incident, which, to some readers, may appear almost incredible. Among his captive birds was a favourite goldfinch, whose wild melody he considered the most perfect he had ever heard: being, however, in company with some canaries, it introduced into its song a foreign note. Its owner then gave it to a lady of his acquaintance, who had often expressed a wish for it. Shortly afterwards, when 
rambling in the wood, which was his favourite resort, he heard the same goldfinch singing in a tree near him. My father did not for a moment doubt the identity of the bird, though he wondered very much how it could be there. On his return to the town, he called at the lady's. 'So, madam, you have lost your goldfinch,' he said. To this the lady assented; and asked, in some surprise, how he could have known the circumstance, as the bird had only made its escape that morning. ' Oh,' replied he, 'I heard it singing in the wood as I came along.' This little anecdote may serve to illustrate the delicacy of his musical ear, for which he was remarkable." 


\section{THE SWIFT.}

THE black martin, or screech martin, is also a name of this bird, which frequents steeples, towers, and other lofty buildings, in the holes of which it makes its nest; but it will sometimes build under the tiles of houses and barns. The nest is made of dried grass, lined with feathers, which the bird, seldom alighting on the ground for any purpose, collects on the wing, sweeping them very dexterously from the earth. While the female is sitting, the male is continually flying to and fro from the spot, and making a screeching noise, which is its only note. In very warm weather these birds soar to a great height; but in cold or moist weather they fly low, in search of flies and other insects, which at that time cannot ascend.

Birds destroy insects in great numbers; and thus, clearing, as they do, the air, they ought to be preserved from molestation. Even one will consume an immense quantity of flies in a short space of time; and were it not for such services, we should often be exposed to 
great inconvenience. In the breeding season, when the young are hatched, and the parent birds are in the habit of making excursions into the country to a considerable distance, for the purpose of collecting flies, to be brought home as food, a gentleman shot a swift. He says, "On picking up my hapless and ill-gotten prey, I observed a number of flies, some mutilated, others scarcely injured, crawling out of the bird's mouth; the throat and pouch seemed absolutely stuffed with them, and an incredible number was at length disgorged. I am sure I speak within compass when I state, that there was a mass of flies, just caught by this single swift, larger than, when pressed close, could conveniently be contained in the bowl of an ordinary tablespoon."

"Lo, the lilies of the field,

How their leaves instruction yield!

Hark to Nature's lesson given

By the blessed birds of heaven!

Every bush and tufted tree

Warbles sweet philosophy :-

'Mortal, flee from doubt and sorrow :

God provideth for the morrow!

" 'Say, with richer crimson glows

The kingly mantle than the rose?

Say, have kings more wholesome fare

Than we, poor citizens of air? 
Barns nor hoarded grain have we, Yet we carol merrily :-

Mortal, flee from doubt and sorrow :

God provideth for the morrow !

" 'One there lives, whose guardian eye

Guides our humble destiny;

One there lives, who, Lord of all,

Keeps our feathers lest they fall:

Pass we blithely, then, the time,

Fearless of the snare and lime,

Free from doubt and faithless sorrow :

God provideth for the morrow !" " 


\section{THE NAGPIE.}

The magpie, in its native state, is a bird of no common beauty. A just idea cannot be formed of its appearance when seen only in captivity. These birds rarely remove far from the dwelling of man, and continue in pairs the whole year. The nest is curiously built for the defence of their young; it is oval in shape, made of sticks, generally the black-thorn, strongly woven together, with only a sufficient entrance on one side : the bottom is lined with fibrous roots, and plastered with earth.

Every kind of animal food seems to be acceptable to the magpie. It will rict in flesh, game, and fish, when these can be procured; it will take up with carrion, insects, and fruit, when accessible; and feed on grain when they are not to be got. All our birds seem to know well its alarming noise. In winter, magpies will assemble in great numbers towards the evening, to roost in some coppice or thicket; but as day approaches they separate again. 
A gentleman travelling in Scotland was one day amusing himself with the objects within his view. On the road between Huntly and Portsoy, he observed two magpies hopping in a peculiar manner round a gooseberry-bush, in a small garden, and flying out and into the bush. He stepped aside to see what they were doing, and found, from the poor man and his wife, that, as there are no trees all round for some miles, these magpies, for several succeeding years, had built their nest, and brought up their young, in this bush ; and, that foxes, cats, hawks, etc. might not interrupt them, they had barricadoed not only their nest, but had encircled the bush with briers and thorns in a formidable manner ; nay, so completely, that it would have cost even a fox, cunning as he is, some days' labour to get into the nest.

The materials in the inside of the nest were soft, warm, and comfortable; but all on the outside so rough, strong, and firmly entwined within the bush, that, without a hedge-knife, hatch-bill, or something of the kind, even a man could not, without much pain and trouble, get at their nest, extended as long as the visitor's arm.

Magpies feed the young brood with frogs, mice, worms, or anything living within their power to subdue. Once it happened, that a magpie, having seized a rat, 
which it was not able to kill, one of the young ones came out of the nest to aid its mother in her struggle with the rat on the outside of the bush : but they were not able to accomplish their object till the father, arriving with a dead mouse, also lent his aid.

These magpies had been faithful to one another for several summers, and drove off their young, as well as every one else that attempted to take possession of the nest. This was carefully repaired and fortified in the spring, with strong, rough, prickly sticks, that they sometimes brought to it by uniting their force, one at the end of each stick, pulling it along, when they were not able to lift it from the ground.

Magpies, like all other birds in a wild state, become vociferous when night approaches. At this time they may be observed, in small detached parties, retiring to their places of roost. They prefer a wood of spruce, pine, or larch; and should it be entered by any one, their noise is incessant. Mr. Waterton describes his capture, through their means, of one of the most desperate marauders that ever scourged the county of York. He had long been an annoyance, and was so exceedingly cunning, that he always contrived to escape pursuit, either by squatting down in the thick cover of the woods, or by a hasty retreat when he found himself 


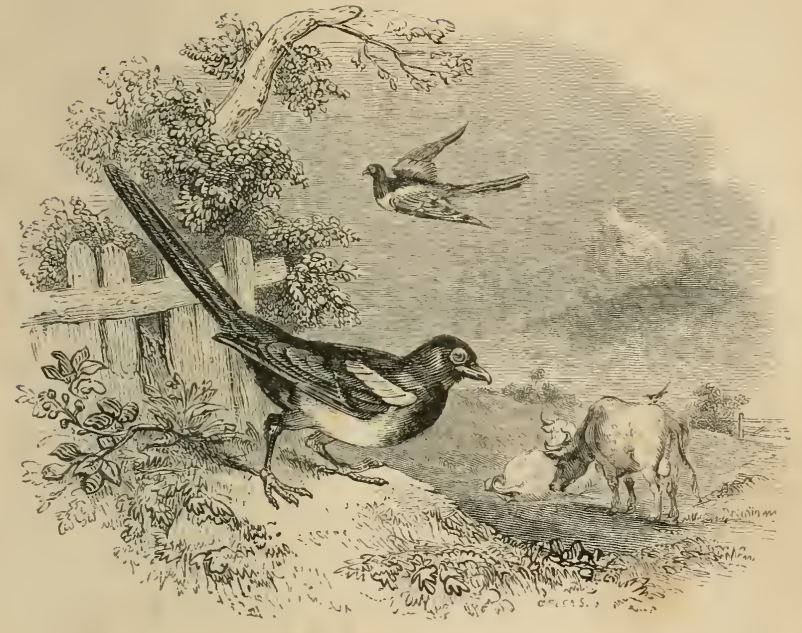

THE MAGPIE. 

approached. He was, however, one day engaged in his usual plunder; he had hanged fourteen hares, and the ground was favourable to his concealment, by being covered with brambles and brushwood; but the noise of the magpies, in the tops of the trees just over the spot, guided his pursuers, and led to his apprehension.

At a village called Thouaré, about three leagues from Nantes, in France, there lived, a few years ago, a magpie, on excellent terms with her master, a justice of the peace, and also with his maid-servant. The former, who was fond of indulging his appetite, had a brood of ducks, which were daily taken by the servant to the fields for food and exercise, while Mag was also an escort. It was observed by the maid that, at the hour fixed for their walk, the magpie regularly placed herself in readiness at the door of the place where the fowls were kept; and one day, just as she had let out the ducks, she was suddenly called off, when, to her great surprise, she saw them all on their way to the field, under the guidance of Mag, who with her beak urged onwards those who were lagging behind. On the following day, the servant purposely let her go alone, when she again took the command of the brood; and from that time she was left to take them out, and bring them in at night. As, however, the justice kept ducks 
for his own pleasure, Mag saw the number of her subjects gradually diminished; but she bore up against her loss with firmness, and conducted the only remaining duck to and from the field with her wonted regularity. At length her care was to cease; the last duck was to follow its companions, and to furnish a dish for the justice's table. It was caught for this purpose by the servant, who was about to execute her master's commands, when Mag's fury became violent: she flew on her, tore her face with her talons and beak, then took to flight, and returned no more to the scene of her wrongs.

The magpie, when reclaimed, becomes commonly very docile: its natural faculties appear improved; it imitates the human roice, and emits various other sounds. A barber at Rome, according to Plutarch, had a magpie which could imitate, to a remarkable extent, almost every noise it heard. On one occasion some trumpets were sounded before the shop, and for a day or two afterwards the magpie was mute, and apparently pensive and melancholy. This greatly surprised those who knew the bird, and they supposed it had been so stunned by the noise of the trumpets, as to lose its power of voice and hearing. Plutarch says, however, that it occupied the time in profound meditation, study- 
ing how to imitate the sound of the instruments; and that it did so, in its first attempt, in all their repetitions, stops, and changes. But its little head would hold no more; its new lesson drove everything else from its remembrance.

Not so is it with the young, when enjoying the advantages of judicious instruction. The more they learn well, the more they may learn. One acquisition is a foundation on which another may be reared. As a child when it has learned its letters, has been preparing to spell and to read; so an acquaintance with a new science or language renders familiarity with others, which they may resemble, or with which they may be connected, less difficult than they would be without it. The woodman may find it impossible to drive the wedge when reversed into a tree, but let him gain an entrance for the point, and the upper part will easily follow. The mind, too, instead of being, like a vessel, hard and rigid, and which will break if more than a small quantity be pressed into it, is endowed with great elasticity, so that it yields, as it were, from time to time, as addition after addition is made to its stores.

With this fact the words of the Divine Redeemer are intimately associated: "He that hath, to him shall be given : and he that hath not, from him shall be taken 
away even that which he hath." Let, then, the young exclaim,

"If I preserit my youth to God,

'Tis pleasing in his eyes:

A flower, when offered in the bud,

Is no vain sacrifice."

Choose thou, O Lord, my inheritance for me. "My Father, thou art the guide of my youth." It may seem to be but "the day of small things" with the individual as to piety; but if he waits on the Lord, he shall renew his strength. Though holy principles in his heart resemble, at first, the grain of mustard-seed, which is the least of all seeds, they shall be like it when it appears as a great tree, on which the fowls of the air may lodge. The strongest believers that ever lived were once "babes in Christ;" and hence there is the greatest encouragement for those who are " accepted in the Beloved" to "follow on to know the Lord." It is equally certain, on the other hand, that those who have only "the form of godliness," will, at last, be entirely stripped of this, and shown to be utterly destitute of its power. 


\section{THE JACKDAW.}

JACKDAWS sometimes make their nests in hollow trees, in rabbit burrows, and in the cavities of cliffs or rocks on the sea-coast. They have been found in great numbers in a chalk-pit, near Godalming, and among the large masses of stone rising in the midst of Salisbury Plain.

A great many jackdaws constantly inhabit the higher parts of Windsor Castle, the noble state residence of the royal family of England. Of another position chosen by this bird, Cowper reminds us, by saying,

"Above the steeple shines a plate, Which turns, and turns, to indicate

From which point blows the weather:

Look up, your brains begin to swim; 'Tis in the clouds, that pleases himHe chooses it the rather."

In some places jackdaws are very fond of chimneys, which are sometimes quite stopped up from the quantity of sticks they collect. A smoky house is considered proverbially a pest; but such a dwelling these birds 
do not mind, as they have been known to attempt building in the chimney of a room where a fire was commonly kept.

The various churches and college buildings of Cambridge supply abundant reception also for their nests; and here they are very numerous. The botanic garden there has three of its four sides enclosed by thicklybuilt parts of the town, and has five churches and five colleges within a short flight of it; and the jackdaws inhabiting these and similar buildings found that the wooden labels placed near the plants would serve for their nests, instead of twigs from trees; that they were ready for use, and were also very near home. The consequence was, that they helped themselves freely to these labels : it is said, that from the shaft of one chimney, in Free-school lane, which was close by the garden, no less than eighteen dozen were taken out, and brought to the curator, and the loss annually cannot be told. The inconvenience that arose will appear, when the necessity of such labels is considered to mark and point out the names of the various plants.

Sonnini thinks, that jackdaws prefer churches to all other places. Thus the fine church of St. Nicholas, in Louraine, is at all times covered with these birds; and 
they build in the churches of Rouen and Mons, while they are never seen on the towers of Orleans, of Tours, or of Angers, though built nearly on the same plan.

The following remarkable story is believed by many to be true. Two boys - thoughtlessly and foolishly indeed - went to take a jackdaw's nest from a hole under the belfry window, in the tower of All Saint's church, Derby. But here two things were absolutely impossible: one was to reach it standing within the building, the other to climb to it from without. What was then to be done? They put a plank through the window, and while the heavier boy was to sit on one end within the building, and thus to steady it, the other was to go to the opposite end, and from thence to capture the wished-for nest. This he succeeded in doing; and immediately he told his companion it contained five young birds, all fledged, when the other answered, "Then I'll have three." "No," said the younger boy, "I run all the danger, and I'll have the three."- " You sha'n't," said his comrade. "Promise me three, or I'll drop you."- "Do, if you like; but you shall have only two," was the fearless reply; when up went the plank, and down he fell, upwards of a hundred 
feet, to the ground. And now the imagination of the reader pictures him stretched out as dead, or at least with broken limbs; but this was not the case. At the moment of his fall, he was holding the birds by their legs : in one hand he had three, and in the other two; and as they felt they were falling, they naturally fluttered their pinions. The boy too wore, at the time, a carter's frock, tied round the neck; this, filled with air from beneath, buoyed him up, and he descended easily to the ground. This he had no sooner reached, than, thinking of the unjust demand of his companion, he looked up, and exclaimed, "Now you shall have none," and ran away, without the slightest injury, to the astonishment of the passers-by at the time, who, with indescribable feelings, had witnessed his most extraordinary descent.

A deliverance so marvellous, through the gracious interposition of the God of Providence, may also caution the young reader against a thoughtless choice of associates. If any are to be taken unscrupulously as companions, the evil that may arise is beyond all calculation. In the present instance, we see intercourse leading to engagement in unlawful pursuits; and an act arising from this which cannot be contemplated without horror. It was as murderous in the sight of God as if 
it had proved fatal. "Enter not into the path of the wicked," says Solomon, "and go not in the way of evil men. Avoid it, pass not by it, turn from it, and pass away. He that walketh with wise men shall be wise: but a companion of fools shall be destroyed." 


\section{THE GREAT AUK.}

THIS species was formerly found on the north coast of Britain, but it has become extremely rare. Some years ago, Mr. Bullock, the proprietor of the London Museum, which once existed in Piccadilly, when making a tour of the Orkney Islands, was informed by the natives that only one male had appeared for a long time, and that this had regularly visited Papa Westra for several years. The female, called by the people the Queen of the Auks, was killed just before his arrival. Mr. Bullock chased the king, or male, for several hours, in a six-oared boat, but without being able to kill him. Though he frequently got near the bird, so expert was it in its natural element, that it pursued its course under water with almost incredible rapidity, and it appeared impossible to shoot him. The smallness of its wings render them useless for flight, the longest quill-feather not exceeding four inches in length; yet these are admirably adapted to its mode of life, acting as fins when the bird dives under water, and enabling it to pursue its prey with astonishing velocity. 


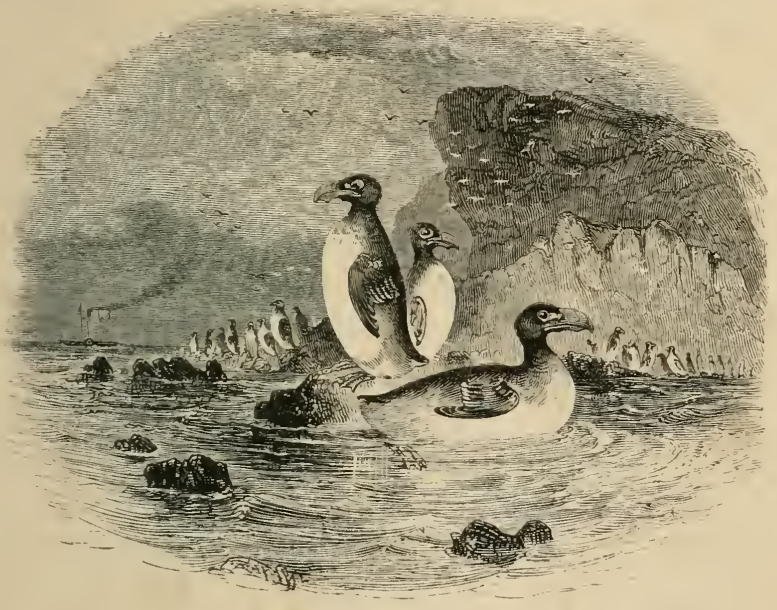

THE GREAT AUK. 



\section{THE LINNET.}

THIs species exhibits much variety, with respect to the red markings, which at certain ages and seasons are found on the head and breast. It is probable, however, that the full plumage of this bird does not take place till the second or third year. Linnets fly in flocks during winter, at which time the males have little or none of the red tints which they put forth on the return of spring, and which are never acquired under confinement. The song of these birds, at once brilliant and soft, consists of many irregular notes, tastefully put together in a clear and sonorous tone, which continues, except at the moulting season, during the whole year. It will also soon acquire the notes of other birds, particularly the nightingale ; and may be brought, in a very short time, to imitate any of our tunes that are whistled to it. 


\section{THE THRUSH.}

happy:-

Clare's description of this well-known bird is very

"Within a thick and spreading hawthorn bush,

That overhung a mole-hill large and round,

I heard, from morn to morn, a merry thrush

Sing hymns to sunshine, while I drank the sound

With joy : and often, an intruding guest,

I watched her secret toils, from day to day,

How true she warp'd the moss to form her nest,

And modell'd it within with wood and clay.

And by and by, like heath-bells gilt with dew,

There lay her shining eggs, as bright as flowers

Ink-spotted over, shells of green and blue;

And there I witness'd, in the summer hours,

A brood of Nature's minstrels chirp and fly,

Glad as the sunshine, and the laughing sky."

The thrush remains in England the whole year, but is supposed to quit the more northern parts in winter. It is not, however, gregarious with us at any time, though it has been observed to pass through Livonia, Courland, and Prussia, together with the missel and fieldfares, in great numbers about Michaelmas, on their way to the Alps. 
The redwing is a species of thrush, much resembling the common one, but is rather less: it differs also as to the distinctness of the spots on the breast, and in the depth of the colour under the wings; the white over the eye is also wanting. It is found in greatest abundance where the hawthorn is plentiful, the berries of that plant yielding it food. It is a migrative species, appearing in great flocks about the end of September, and frequently accompanied by fieldfares. When the weather is severe, or their food becomes scarce, their flight is continued south. In the hard winter of 1799 , vast numbers of them resorted to the west of England, where a sudden fall of snow, unusually deep in that part, cut them off from all supply of food; and being too weak to attempt a passage across the sea to a warmer climate, thousands of them, and their companions the fieldfares, were starved to death.

Happily for us, the feathered tribes which leave our land do so only for a time : they appear at the appointed season, calling for the acknowledgment -

"Beautiful birds of lightsome wing,

Bright creatures that come with the voice of spring,

We see you array'd in the hues of the morn;

Yet ye dream not of pride, and ye wist not of scorn.

Though rainbow-splendour around you glows,

Ye vaunt not the hues that Nature bestows: 
Oh! what a lesson for glory are ye!

How ye preach the grace of humility !

"Sweet birds, that breathe the spirit of song,

And surround Heaven's gate in melodious throng-

Who rise with the earliest beams of day,

Your morning tribute of thanks to pay,

You remind us likewise that we should raise

The voice of devotion and song of praise;

There's something about you that points on high,

Ye beautiful tenants of earth and sky !"

The influence of their notes on the mind of an invalid has often been noticed. Miss Graham thus writes in reference to them :-

"When I lay in bed last summer, unable to speak or move for many hours in the day, the song of the birds furnished me with an inexhaustible source of amusing observation. I could not but feel grateful to the melodious little creatures, who beguiled me of half my pain, and made the weary hours of sickness fly away upon wings as light as their own. As if led by an instinctive sympathy, numbers of blackbirds and thrushes came to build their nests round our garden; and the woodpigeons, which had been silent the year before, renewed their soft notes in the high trees by the parsonage lawn. However, they were shy, and I thought myself fortunate, if once or twice in the day their gentle cooing found its way to my ear. 


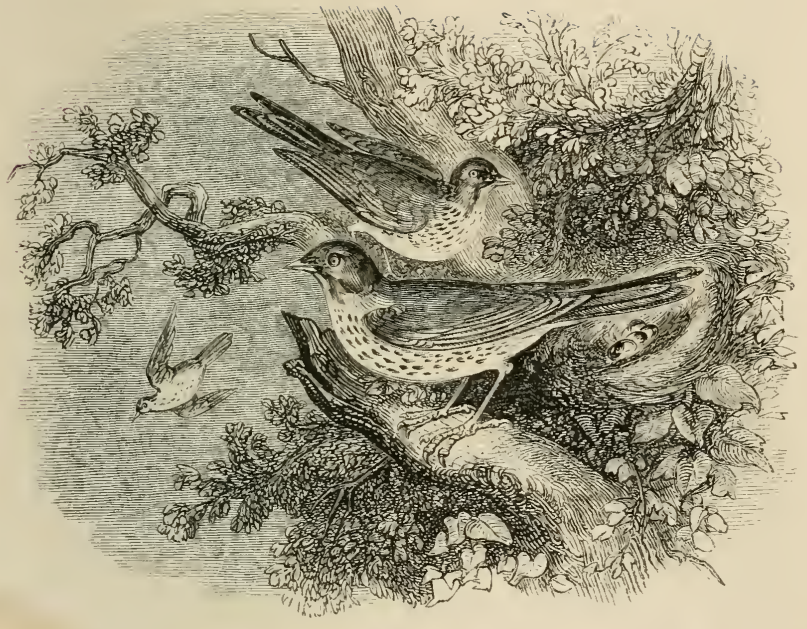

THE REDWING。 

"But there was one thrush, whose notes I soon learned to distinguish from all the other thrushes. Every morning I listened for his voice, which was sure to precede the matins of all the other birds. In the daytime, his brilliant tones were mingled and almost lost in the general melody; but as soon as the sun was preparing to set, when the blackbirds had either sung themselves to sleep, or were flown off to keep their festivals elsewhere, then was my thrush's practising time. $\mathrm{He}$ was kind enough to select a tree not far from my window, while the other thrushes placed themselves at a respectful distance, and edged in a note here and there as they could. He opened the rehearsal with a number of wild trills and calls, which I could not well understand, only they were very sweet and cheering to me; and he would pause between each, till a soft response was heard from some distant bough. But when he had fixed upon a little cadence which pleased him, it became a more serious business. Strange to say, I could always tell when this would be; for what pleased me particularly was sure to please him : so true it is that Nature has given the same perception of melody to man and birds. He would chant it over in a low tone two or three times, as if to make himself sure of it; then he carolled it out with triumphant glee; then stopped short 
on a sudden, as much as to say to his rivals, "Which of you can imitate my strains?'

"Their notes sounded most sweet at various distances during these little intervals; but they seemed conscious of their inferiority to my favourite, who would suddenly break out into the same melody, upon which he had doubtless been musing all the while, enriching it by some little note or trill, the wildest and most touching that ever came into a thrush's heart. I needed neither concert nor music-master while I could listen to the untaught, but not unpremeditated harmony of this original professor: nor could I quarrel with the sickness, which had been the means of developing another link in that mysterious chain which binds me to the rest of creation, by opening my ear and my heart more than ever to the language of universal Nature." 


\section{THE CORMORANT.}

THIs bird breeds on most of our rocky coasts, where an insulated eminence may sometimes be observed covered with the nests of cormorants, and composed of sticks and seaweed. In the winter they are frequently found in fresh-water rivers far distant from the sea; and eight or ten have been observed together far up the river Usk, perched on a tree.

This bird is a great destroyer of fish; and by frequent diving, the wings often become so wet, that it is unable to fly. It is said to have been trained and used for fishing, as hawks are for fowling, and that a tight collar was put round the neck, to prevent the cormorant swallowing its prey. Its dexterity in fishing is very great. Aware of its own powers, if a fish is thrown into the water at a distance, it will dive immediately, take a direct line to the spot, and frequently capture the fish before it falls to the bottom.

A cormorant, taken by an able naturalist, is described as extremely docile, of a grateful disposition, and with- 
out the smallest tincture of a savage or vindictive spirit. In less than a week after its capture, it was perfectly familiar, and made one in the family circle round the fire, suffering even the caresses of the children. When removed to an aquatic menagerie, it lived in perfect harmony with a whistling swan, a barnacle goose, various sorts of ducks, and several other birds. If it got out, it never attempted to ramble, but walked to the house, entered the first open door, regardless even of a dog, and became, in fact, "troublesomely tame."

Here, then, we pause in our consideration of British Birds, not because all have been looked at, (for many remain unnoticed,) but because the limit assigned to this volume is reached. Nor have we forgotten the great and gracious Being who created them all. He ought to be constantly and devoutly regarded :-

" The God of nature and of grace,

In all his works appears:

His goodness through the earth we trace-

His grandeur in the spheres.

"The forests in his strength rejoice:-

Hark ! on the evening breeze, As once of old, Jehovah's voice

Is heard among the trees. 


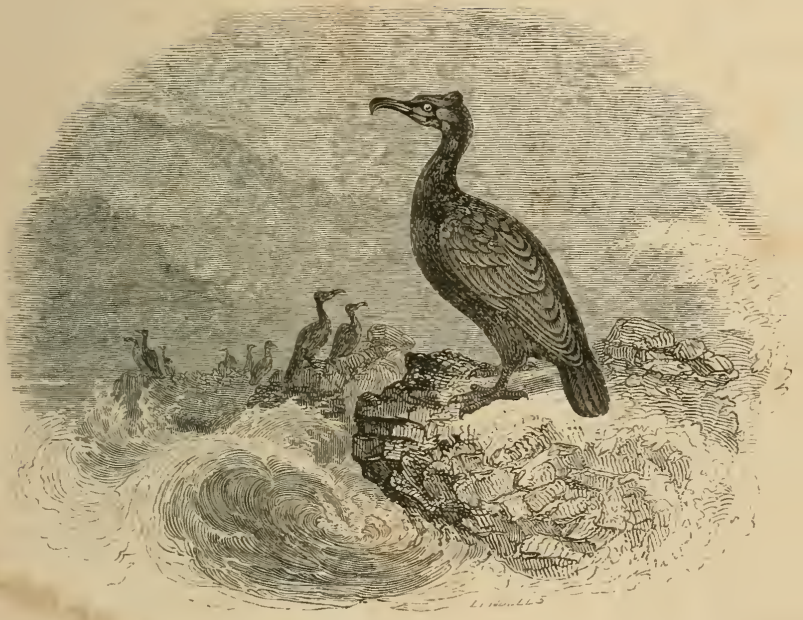

THE CORMORANT. 
"Here on the hills he feeds his herds,

His flocks on yonder plains;

His praise is warbled by the birds :-

Oh could we catch their strains!

"Mount with the lark, and bear our song

Up to the gates of light ;

Or, with the nightingale, prolong

Our numbers through the night."

Enough has been said, however, to stimulate and encourage the desire for a more extended and intimate acquaintance with the feathered tribes. A wise man said, "They seem to do all the things they ought; and to act with what may be called a steady common sense in their respective situations. I have never seen a bird do a foolish thing for a creature of their powers, frame, and organs, and in their state." Of what reader of this volume could a similar declaration with truth be made?

Still the instinct of birds is what it was. All the winged inhabitants of Paradise wove their first nests as curiously and well as the wood-minstrels of our evil day. The nightingale is just what it was six thousand years ago: the eagle is no more capable of advancement than the wren. They do not improve, and they never will.

Ours is a far different course. It is for us to be always learning - to add to the stores of memory every 
day and every hour. Literature, science, above all, the word of God, requires us to advance in knowledge. Meanwhile, the moral state should be improved - the heart more influenced by holy affections-the conscience more prompt and equitable in its decisions. For all this Divine power is needed; for " every good gift and every perfect gift is from above:" to that power, then, let us look, on it let us rely, and its experience let us constantly supplicate, until the progress of time shall be complete, and we enter on that of a glorious immortality!

THE END. 



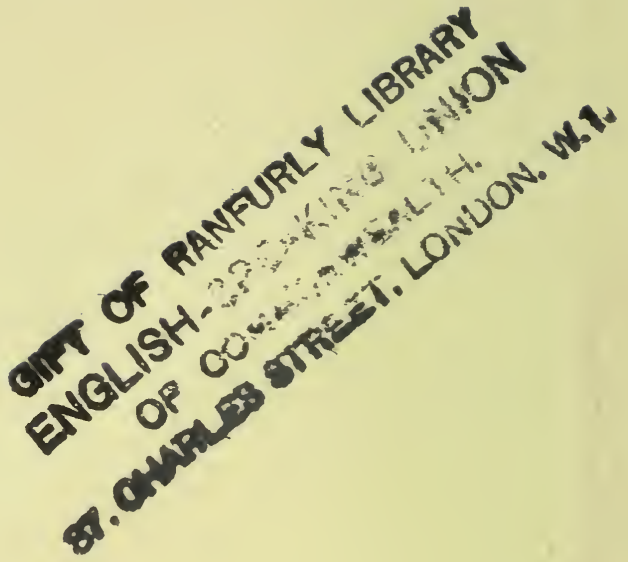


UC SOUTHERN REGIONAL LIBRARY FACILITY

B 0000030429

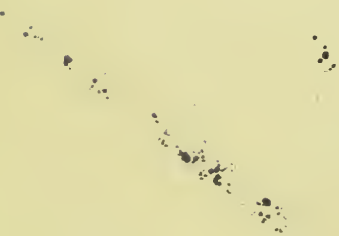



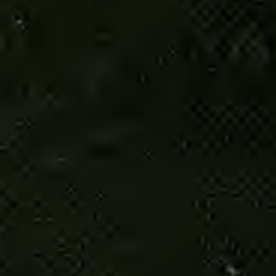

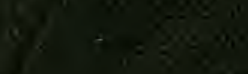

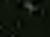

